\title{
Consolidated Fuel Shielding Calculations
}

Prepared for the U.S. Department of Energy

Office of Environmental Restoration and

Waste Management

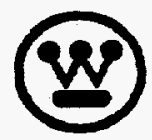

Westinghouse Hanford Company Richland, Washington

Hentord Operations and Engineering Controctor for the

U.S. Depertment of Energy under Contrect DE-ACO6-87RL10930
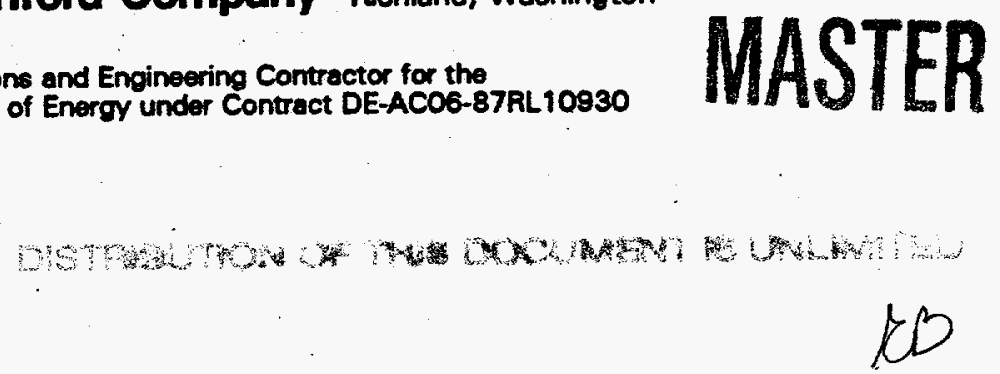

Approved for Public Release 
IECAL DISCLAMER

This report was propared as an account of work eponsored by an agency of the United States Government. Neither the United States Govermment nor any egancy thereof, nor any of their employees, nor any of their contractors, aubcontractors or their employeos, mekes any warranty, express or implied, or assumes any legal liability or responsibility for the accuracy, completeness, or any third party's use or the results of auch use of any information, apparatus, product, or process disclosed, or represents that its use would not infringe privately owned rights. Reference herein to any specific commercial product, process, or service by trade name, trademark, manufacturer, or otherwise, does not necesserily constitute or imply its endarsement, recommendation, or favoring by the United States Government or any agency thereof or its contractors or subcontractors. The views and opinions of authors expressed herein do not necessarily state or reflect those of the United States Government or any agency thereof.

This report has been reproduced from the best available copy.

Printed in the United States of Americe

DISCLM-2.CHP (1-91) 


\section{DISCLAIMER}

\section{Portions of this document may be illegible in electronic image products. Images are produced from the best available original document.}


2. To: (Receiving Organization)

\section{Distribution}

5. Proj/Prog/Dept/Div: 80520

8. Originator Remarks:

APPROVAL / RELEASE
3. From: (Originating Organization)

Nuclear Analysis and

Characterization

6. Cog/Proj Engr: WD Wittekind
1. EDT 130161

4. Related EDT No:

$N / A$

7. Purchase Order No:

$$
\text { N/A }
$$

9. Equip/Component No: $N / A$

10. System/BIdg/Facility:

K Basin

12. Major Assm Dwg No:

$$
N / A
$$

13. Permit/Permit Application No. 1) $/ A$

14. Required Response Date:

$1 C / 91$ cursolidated fuel storage in the $105 \mathrm{KE}$ Basin. This document supports triple stacking of irradiated fuel canisters, required by irradiated fuel storage consolidation. This document is based on single canister dose rate measurements, ISOSHLD-II calculations, and the reconstructed SCATS database.

\section{DATA TRANSMITTED}

15

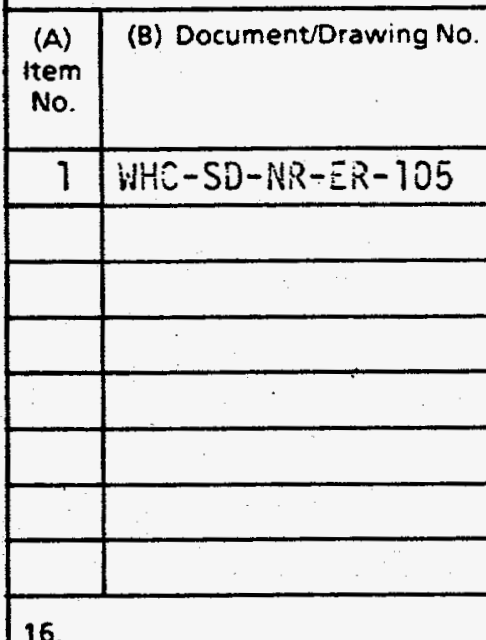

\begin{tabular}{|c|c|}
$\begin{array}{c}\text { (C) Sheet } \\
\text { No. }\end{array}$ & $\begin{array}{r}\text { (D) Rev } \\
\text { No. }\end{array}$ \\
\hline At广 & 0
\end{tabular}

(E) Title or Description of Data Transmitted

(F)

(G)

\begin{tabular}{|c|c|}
\hline$(H)$ & $(1)$ \\
\hline $\begin{array}{c}\text { Origi- } \\
\text { nator } \\
\text { Dispo- } \\
\text { sition }\end{array}$ & $\begin{array}{c}\text { Receiv- } \\
\text { er } \\
\text { Dispo- } \\
\text { sition }\end{array}$ \\
\hline
\end{tabular}

\begin{tabular}{|l|l|}
\hline & \\
\hline & \\
\hline & \\
\hline & \\
\hline & \\
\hline &
\end{tabular}
Consolidated Fuel Shielding Calculations
16

Impact Level (F)

$1,2,3$, or 4 see MRP 5.43 and $E P-1.7$

\begin{tabular}{l|l|l} 
(G) & $(\mathrm{H})$ & 17 \\
\hline
\end{tabular}

Rea- Disp (J) Name son

\begin{tabular}{|l}
\multicolumn{1}{|c}{ Rea } \\
\hline 1. Approval \\
2. Release \\
3. Information
\end{tabular}

Reason for Transmittal (G)

\section{KEY}

4. Review

5. Post-Review

6. Dist (Receipt Acknow. Required)

\section{SIGNATURE/DISTRIBUTION}

I(See impact Level for required signatures)

\begin{tabular}{ll|l} 
(K) Signature & (L) Date (M) MSIN & (J) Name
\end{tabular}

(J) Name

Disposition (H) \& (I)

4. Reviewed no/comment

$\begin{array}{ll}\text { 1. Approved } & \text { 4. Reviewed no/comment } \\ \text { 2. Approved w/comment } 5 \text {. Reviewed w/comment }\end{array}$

3. Disapproved w/comment 6. Receipt acknowledged

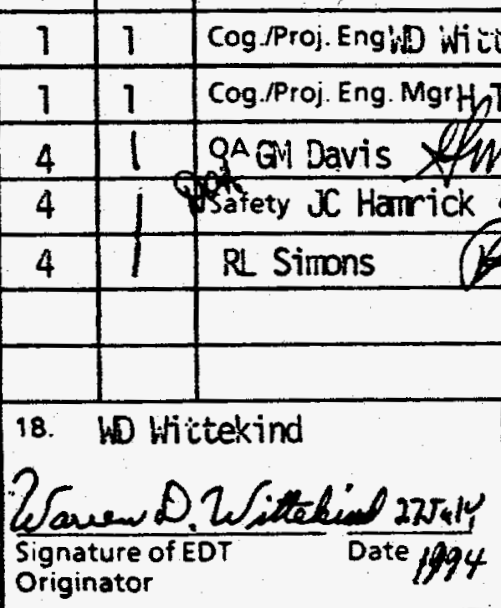

19.

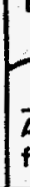

20

H. Toffer Autholized Representative $4 / \frac{19}{\text { Date }}$ for Receivigg Organization

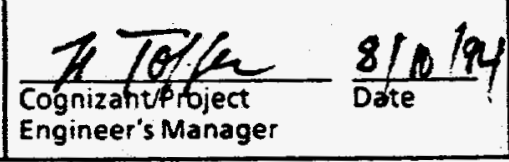

(K) Signature
(L) Date

(M) MSIN
(G) (H)

\begin{tabular}{|l|l|}
\hline $\begin{array}{l}\text { Rea- } \\
\text { son }\end{array}$ & Disp \\
\hline & \\
\hline & \\
\hline & \\
\hline & \\
\hline & \\
\hline & \\
\hline & \\
\hline
\end{tabular}

21. DOE APPROVAL (if required) Ltr No.

$\square$ Approved

$\square$ Approved w/comments

$\square$ Disapproved w/comments

BD -7400-172 (2/89) 


\section{RELEASE AUTHORIZATION}

\begin{tabular}{ll}
\hline Document Number: & WHC-SD-NR-ER-105 \\
\hline Document Title: & Consolidated Fuel Shielding Calculations \\
\hline Release Date: & $9 / 7 / 94$
\end{tabular}

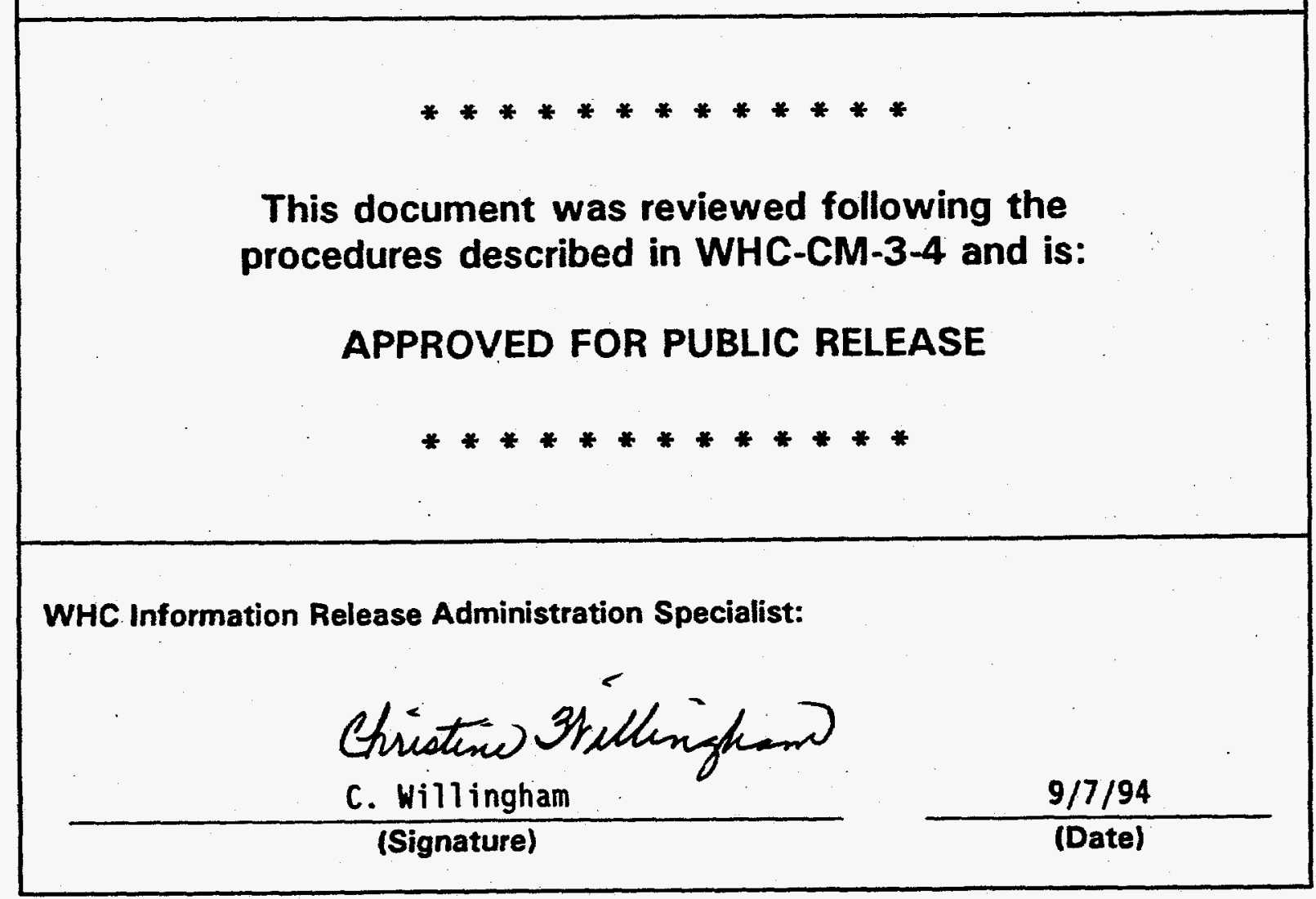




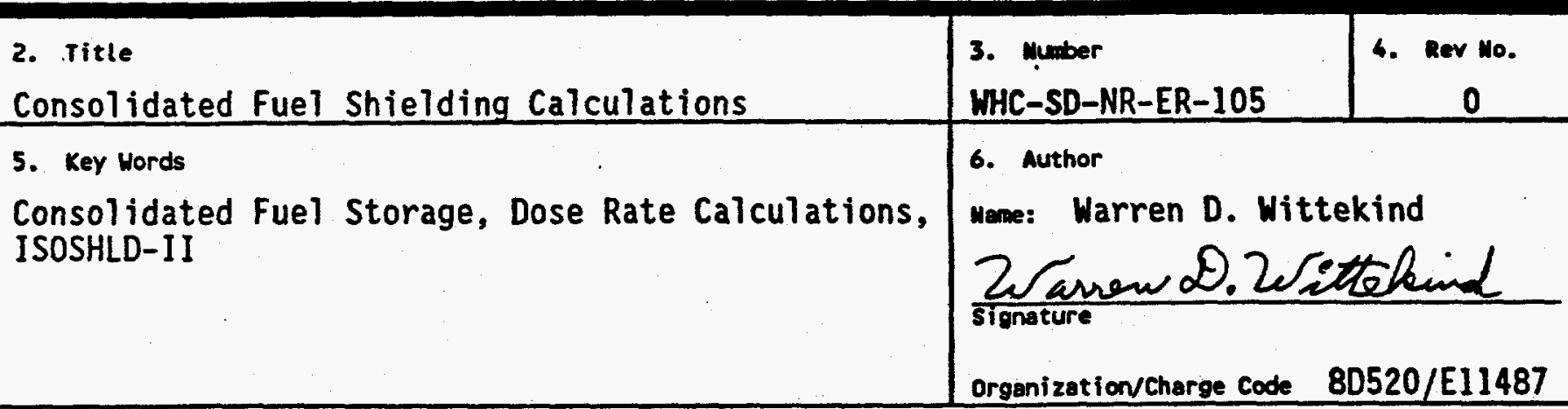

\section{Abstract}

Irradiated fuel radiation dose rate and radiation shielding requirements are calculated using a validated ISOSHLD-II model. Comparisons are made to experimental measurements. ISOSHLD-II calculations are documented.

8. POMOSE AND USE OF DOCUMENT - This document was prepared fon withim he $y$ s 2 epartment of Energy and its contractors to be wed- It to perform, direct, or integre work under

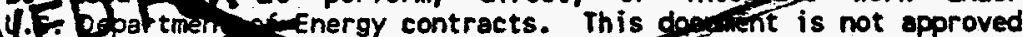
opRONopublicris 0 - il reviewed.

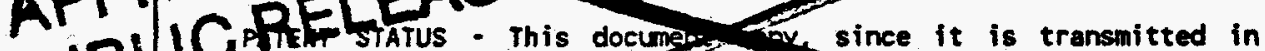

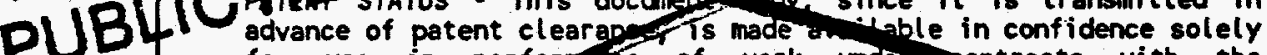
10 for use in perfor.tke of work undel nontracts with the

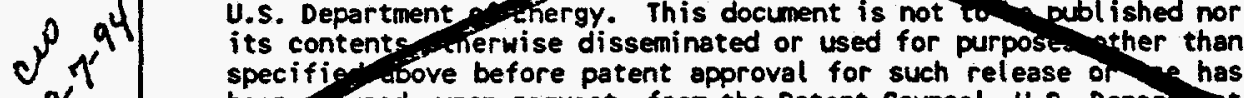
been ctured, upon request, from the Patent Counsel, U.S. Departinat Chergy field office, Richland, WA.

DISCLAIMER - This report was prepared as an account of work sponsored by an agency of the United States Government. Neither the United States Government nor any agency thereof, nor any of their employees, nor any of their contractors, subcontractors or their employees, makes any warranty, express or implied, or assumes any legal liability or responsibility for the accuracy, completeness, or any third party's use or the results of such use of any information. apparatus, product, or process disclosed, or represents that its use would not infringe privately owned rights. Reference herein to any specific commercial product, process, or service by trade nane, trademark, manufacturer, or otherwise, does not necessarily constitute or imply its endorsement, recomendation, or favoring by the United States Government or any agency thereof or its contractors or subcontractors. The views and opinions of authors expressed herein do not necessarily state or reflect those of the United States Goverment or any agency thereof.

10. RELEASE STAMP

CFFICIAL PELEAFE (1) Jist) 1904:

DATE

22 Station 7 


\title{
Consolidated Fuel Shielding Calculations
}

\author{
W. D. Wittekind
}

Date Published

September 1994

Prepared for the U.S. Department of Energy Office of Environmental Restoration and Waste Management

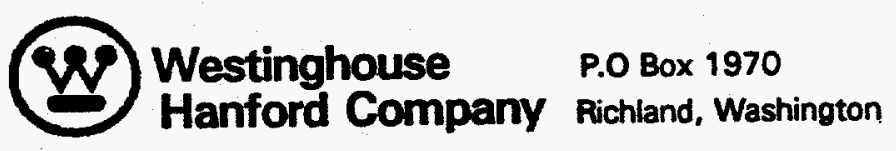

Hanford Operations and Engineering Contractor for the

U.S. Department of Energy under Contract DE-AC06-87RL10930 


\section{EXECUTIVE SUMMARY}

Consolidation of 105-KE Basin irradiated fuel into the 105-KW Basin will require double or triple stacking canisters closer to the surface of the basin water. This document calculated minimum required water shielding thickness consistent with present radiation shielding design, personnel protection requirements, and acceptable dose rate limits. The present Kaiser designs, sketches ES-N040-SO3 (Option A) and ES-N040-SO4 (Option B) (Kaiser 1994), indicate $227.01 \mathrm{~cm}$ (7 ft $5 \%$ in.) height for triple-stacked canisters under Option B. This is acceptable according to present radiation shielding requirements. Since Option B with $4.445 \mathrm{~cm}$ ( $1 \frac{3}{4}$ in.) vertical spacing between canister layers is acceptable, all designs with less than $4.445 \mathrm{~cm}$ ( $1 \frac{3}{4}$ in.) vertical spacing are also acceptable.

This document considered gamma ray dose rates direct from irradiated fuel. This document did not consider dose rates due to radioactive isotopes, such as ${ }^{137} \mathrm{Cs}$, that may have migrated away from the fuel but still remain in the basin, or localized contamination on walls, in pipes, etc.

Experimentally measured canister dose rates were compared to ISOSHLD-II models for single canister geometry. The ISOSHLD-II single canister model was converted into the canister storage location model, then into a larger storage array model and finally into a 1/3-basin model (storage bay). Fuel irradiation and decay were accommodated by determining the highest dose rate key from the reconstructed SCATS database as a function of irradiation and decay time. An average canister drawn from the irradiated fuel batch with the highest dose rate became the basis for the full-basin calculation. 
There is routine movement of basin canisters by lifting them up and out of their array position and moving across the array to another location. The active basin calculation combined the entire static basin array with the single canister dose rate by simple addition. The only dose contribution at the dose point is from the top layer in the array; lower array levels do not contribute to this dose rate.

The following table shows the minimum required water shielding thickness for the reference date of January 31, 1995, and three subsequent decay times. The current operational limit of three canisters per storage bay out of storage and on hoists will not be affected.

ISOSHLD-II Calculated Minimum Water Shield Above Storage Array.

\begin{tabular}{|l|l|l|l|l|}
\cline { 2 - 5 } \multicolumn{1}{c|}{} & $\begin{array}{l}\text { Reference } \\
\text { Date }+0 \mathrm{~d}\end{array}$ & $\begin{array}{l}\text { Reference } \\
+1000 \mathrm{~d}\end{array}$ & $\begin{array}{l}\text { Reference } \\
+3000 \mathrm{~d}\end{array}$ & $\begin{array}{l}\text { Reference } \\
+5000 \mathrm{~d}\end{array}$ \\
\hline $\begin{array}{l}\text { Limited } \\
\text { Access Time }\end{array}$ & $210.4 \mathrm{~cm}$ & $209.4 \mathrm{~cm}$ & $207.6 \mathrm{~cm}$ & $205.8 \mathrm{~cm}$ \\
\cline { 2 - 6 } & $6 \mathrm{ft} 11 \mathrm{in}$. & $6 \mathrm{ft} 11 \mathrm{in}$. & $6 \mathrm{ft} 10 \mathrm{in}$. & $6 \mathrm{ft} 10 \mathrm{in}$. \\
\hline $\begin{array}{l}\text { Unlimited } \\
\text { Access Time }\end{array}$ & $240.8 \mathrm{~cm}$ & $239.7 \mathrm{~cm}$ & $237.8 \mathrm{~cm}$ & $236.0 \mathrm{~cm}$ \\
\cline { 2 - 6 } & $7 \mathrm{ft} 11 \mathrm{in}$. & $7 \mathrm{ft} 11 \mathrm{in}$. & $7 \mathrm{ft} 10 \mathrm{in}$. & $7 \mathrm{ft} 9 \mathrm{in}$. \\
\hline
\end{tabular}

NOTES:

Calculated distance is from top of fuel storage array to water surface.

Dose point is $152.4 \mathrm{~cm}$ ( $5 \mathrm{ft}$ ) air above water surface.

Situation: one canister $91.44 \mathrm{~cm}(3 \mathrm{ft})$ Above storage array.

Reference date is January $31,1995$.

Limited access time (l hour/day), calculated dose rate is $2 \mathrm{mR} / \mathrm{h}$.

${ }^{2}$ Unl imited access time, calculated dose rate is $0.2 \mathrm{mR} / \mathrm{h}$.

The current operational level of $K$ basin pools is $490 \pm 15 \mathrm{~cm}(16.0 \pm$ $0.5 \mathrm{ft}$ ) measured from the bottom of the pool to the surface of the water. The Kaiser engineering study sketches, ES-N040-SO3 (Option A) and ES-N040-SO4 (Option B) (Kaiser 1994), designed $227.01 \mathrm{~cm}$ (7 ft 5\% in.) for canisters 
three high under Option B. This design would leave $260.67 \pm 15.24 \mathrm{~cm}$ (8 ft $6 \%$ in. $\pm 0.5 \mathrm{ft}$ ) of water shielding above the top canister. At a minimum there would be $245.43 \mathrm{~cm}$ ( $8 \mathrm{ft} k \mathrm{in}$.) of water shielding above the top canister when stacked three high. Since the design minimum water shield of $245.43 \mathrm{~cm}(8 \mathrm{ft} \mathrm{k}$ in.) is greater than the minimum required water shield thickness of $241.3 \mathrm{~cm}$ ( $7 \mathrm{ft} 11 \mathrm{in}$ ), this proposed design is acceptable according to the radiation shielding design, personnel protection requirements and acceptable dose rate limits. 


\section{CONTENTS}

1.0 INTRODUCTION ...................... 1-1

1.1 PURPOSE ...................... 1- . . .

1.2 SCOPE . ........................ . . .

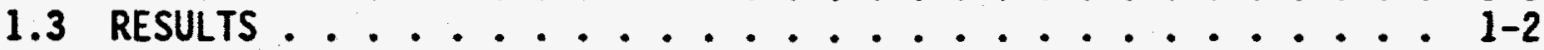

2.0 DISCUSSION . . . . . . . . . ...... 2-1

2.1 CANISTER DOSE RATE MEASUREMENTS ........... $2-1$

2.2 CANISTER SIDE ISOSHLO-II MODELS $\ldots \ldots \ldots$

2.3 CANISTER TOP ISOSHLD-II MODELS .......... 2-10

2.4 STATIC STORAGE ARRAY ISOSHLD-II MODEL $\ldots \ldots$

2.4.1 Canister Storage Location Geometry......... 2-16

2.4.2 Reconstructed SCATS Database ......... 2-18

2.4.3 Single Canister Irradiation Calculation ...... 2-19

2.4.4 Static Storage Array Geometry ......... 2-24

2.5 ACTIVE STORAGE ARRAY ISOSHLD-II CALCULATION: . . . 2-24

2.5.1 Active Storage Array ISOSHLD-II Model ...... 2-28

2.5.2. Storage Array with Multiple Elevated Canisters . . . . 2-30

2.5.3 Temperature Effect on Water Density and Radiation Shielding ........... 2-32

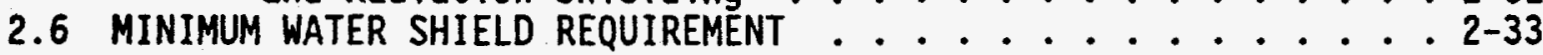

3.0 ISOSHLD CODE COMPARISON ................ . . . . .

3.1 PURPOSE OF COMPARISON . . . . . . ........ 3-1

3.2 SCOPE OF COMPARISON . . . . . . . . . . $3-1$

3.3 RESULTS OF ISOSHLD COMPARISON ............. 3-1

3.4 CONCLUSION OF ISOSHLD COMPARISON ............ 3-8

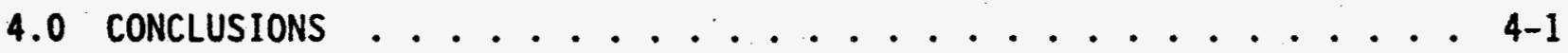

5.0 REFERENCES ....................... 5-1 APPENDICES

A RECONSTRUCTED SCATS ACCOUNTABILITY DATABASE . . . . . . . A-1

B DOSE RATE MEASUREMENT CANISTERS WERE STAINLESS STEEL . . . . . . B-1

C REPRESENTATIVE ISOSHLD-II INPUT FILES ........... . . ISOSHLD-II Input for Half Canister Model $5 T_{A}^{\circ}, 6$ wt ${ }^{240} 0_{u}^{\circ}: \cdots C-3$ ISOSHLD-II Input for Haif Canister Model 6TB, 16 wt\% $240 \mathrm{Pu}: \mathrm{C}^{\circ}$ ISOSHLD-II Input for Single Canister Model Bi, 16 wt\% ${ }^{240} \mathrm{Pu}: \mathrm{C}_{-7}$ ISOSHLD-II Input for Static Basin Model B1800, 16 wt\% ${ }^{240} \mathrm{Pu}: \mathrm{C}_{-9}$

D REPRESENTATIVE ISOSHLD-II OUTPUT . . ........... . . . . .

E INDEPENDENT REVIEWER'S COMMENT ................ E-1 
WHC-SD-NR-ER-105 ReV. 0

\section{LIST OF FIGURES}

1 Basin Water Shielding Geometry. ............. 1-3

2 Active Basin ISOSHLD-II Dose Rates. . . . . . . . . . 1-4

3 Static Basin ISOSHLD-II Dose Rates. . . . . . . . . . 1-6

4 Canister Side ISOSHLD-II Models. ............ 2- . . . .

5 Canister Top ISOSHLD-II Models. . . . . . . . . . 2-13

6 Storage Location ISOSHLD-II Models. . . . . . . . . . . 2-17

7 Static Storage Array ISOSHLD-II Models. . . . . . . . . 2-26

8 Active Basin ISOSHLD-II Modet. . . . . . . . . . . . 2-29

9 Minimum Water Thickness Basin Geometry. . . . . . . . 2-36

10 ISOSHLD Dose Rate Comparison. . . . . . . . . . . 3-2

11 ISOSHLD Dose Rate Comparison-Detail. . . . . . . . . 3-3

12 ISOSHLD 4.0 to ISOSHLD-II Ratio. .............. 3-4

13 ISO-PC 1.90 to ISOSHLD-II Ratio. ............. 3-5

14 ISOSHLD 4.0 to ISO-PC 1.90 Ratio. . . . . . . . . 3-7 
WHC-SD-NR-ER-105 Rev. 0

\section{LIST OF TABLES}

1 Calculated Minimum Water Shield Above Storage Array ........ 1-2

2 Two-Region Canister Side ISOSHLD-II Models .......... 2-2

3 Two Region Canister Side ISOSHLD-II Dose Rates ......... 2-4

4 Three-Region Canister Side ISOSHLD-II Models ........ 2-7

5 Three-Region Canister Side ISOSHLD-II Dose Rates ....... 2-8

6 Four-Region Canister Top ISOSHLD-II Models ......... 2-11

7 Four-Region Canister Top ISOSHLD-II Dose Rates . . . . . . . 2-12

8 ISOSHLD-II Gamma Ray Attenuation and Effective Penetration .... 2-14

9 Five-Region Canister Top ISOSHLD-II Dose Rates . . . . . . . 2-15

10 Five-Region Storage Location ISOSHLD-II Models . . . . . . 2-16

11 Five-Region Storage Location ISOSHLD-II Dose Rates . . . . . . 2-18

12 Irradiation Exposure, Decay ISOSHLD-II Comparison . . . . . . 2-20

13 RIBD Calculated ${ }^{137} \mathrm{Cs}$ Inventory. .............. 2-21

14 ORIGEN2 Results for Determining ${ }^{137}$ Cs Activity . . . . . . . 2-22

15 ORIGEN2 Calculated Gamma Ray Production ........... 2-25

16 Static Storage Array ISOSHLD-II Dose Rates . . . . . . . . 2-27

17 Active Storage Array Dose Rate Calculations . . . . . . . . 2-28

18 Active Storage Array ISOSHLD-II Dose Rates ......... 2-30

19 Radiation Dose Rate Increase Due to Water Temperature. . . . . . 2-33

20 Shield Design Criteria ............... . . . . . . . . . .

21 ISOSHLD Dose Rate Comparisons . . . . . . . . . . . . . 3-6

22 ANS-6.4.3 Water Buildup Factors $(R) \ldots \ldots$. . . . . . . . .

23 Calculated Minimum Water Shield Above Storage Array . . . . . . 4-1 
WHC-SD-NR-ER-105 Rev. 0

This page intentionally left blank. 
WHC-SD-NR-ER-105 Rev. 0

CONSOLIDATED FUEL SHIELDING CALCULATIONS

\subsection{INTROOUCTION}

\subsection{PURPÓSE}

Consolidated fuel storage considers combining irradiated $N$ Reactor fuel from both 105-KE Basin and 105-KW Basin into just one of the basins. Since the number of canisters in the two basins is greater than the number of canister locations in a single basin, the canisters will need to be stacked two or three high. Stacking the canisters will reduce the water shielding above the upper canisters, so it is important to calculate the minimum required water shielding above the top canister in the canister storage array. The purpose of this document is to calculate this minimum required water shielding thickness above the stored irradiated uranium, consistent with Westinghouse Hanford Company policy (WHC-CM-4-9) and "as low as reasonably achievable" (ALARA) principles.

Gamma ray dose rates generated from $N$ Reactor irradiated fuel were calculated using ISOSHLD-II (Engel et al. 1966; Mansius 1969), in support of consolidated fuel storage. This document contains the determination of the minimum water shielding above the irradiated fuel storage array, consistent with radiation shielding and acceptable dose rate practices.

\subsection{SCOPE}

There are three sources of gamma dose rates in the $K$ Area fuel storage basins: (1) gamma dose rates direct from the irradiated fuel, (2) gamma ray dose rate from radioactive isotopes, such as ${ }^{137} \mathrm{Cs}$, that have migrated away from the fuel but remain in the basin, and (3) gamma ray dose rates from surroundings, such as contamination on pipe walls. This report details the gamma ray dose rates directly from irradiated fuel.

The gamma ray dose rate direct from irradiated fuel depends on water shielding thickness. The smallest water shielding thickness consistent with radiation shielding protection practices was calculated from ISOSHLD-II models that were tested with supporting measurements.

The current operational level of $K$ basin pools is $490 \pm 15 \mathrm{~cm}(16.0 \pm$ $0.5 \mathrm{ft}$ ) measured from the bottom of the poot to the surface of the water. The Kaiser engineering study sketches ES-NO40-SO3 and ES-NO40-SO4 (Kaiser 1994) designed $227.01 \mathrm{~cm}$ ( $7 \mathrm{ft} 5 \%$ in.) for canisters stacked three high $\left(\frac{1}{2}+29+1 \frac{3}{4}\right.$ Option $B+29+1 \frac{3}{4}$ Option $B+27 \%$ lid top $=89 \%$ in.). This design would leave only $260.67 \pm 15.24 \mathrm{~cm}$ ( $8 \mathrm{ft} 6 \%$ in. $\pm 0.5 \mathrm{ft}$ ) of water shielding above the top canister. At a minimum, this would be $245.43 \mathrm{~cm}(8 \mathrm{ft} \mathrm{H} \mathrm{in.)}$ of water shielding above the top canister lid when stacked three high. Since Option B with $4.445 \mathrm{~cm}$ ( $1 \frac{3}{4}$ in.) vertical separation is being considered as the limiting case, all vertical separations between canister layers less than $4.445 \mathrm{~cm}$ ( $1 \frac{3}{2}$ in.) are also being covered. Option $A$ has $0 \mathrm{~cm}(0 \mathrm{in.})$ between the canister layers. 
The geometry considered in these shielding calculations is shown in Figure 1. There is an array of irradiated fuel storage canisters with a single canister lifted $91.44 \mathrm{~cm}(3 \mathrm{ft})$ above the array. The canisters below the top level in the array do not add to the calculated dose rate at the dose point because of the shielding of a canister; in fact, only about the upper $5 \mathrm{~cm}$ ( $2 \mathrm{in}$.) of the fuel element contribute to the dose rate at the dose point. The dose point is calculated above the floor grating, taken as $152.4 \mathrm{~cm}(5 \mathrm{ft})$ above the water surface.

\subsection{RESULTS}

Minimum water shielding thickness above the irradiated fuel storage array was calculated and the results are shown in Table 1 . Since the minimum required water shield thicknesses calculated by ISOSHLD-II are less than the design minimum water thickness, the proposed design is acceptable according to the radiation shielding requirement. Dose point is $152.4 \mathrm{~cm}(5 \mathrm{ft})$ of air above water surface of the calculated water shield.

Table 1. Calculated Minimum Water Shield Above Storage Array.

\begin{tabular}{|c|c|c|c|c|}
\hline & $\begin{array}{l}\text { Reference } \\
\text { date +0 } d\end{array}$ & $\begin{array}{l}\text { Reference } \\
+1000 \mathrm{~d}\end{array}$ & $\begin{array}{l}\text { Reference } \\
+3000 d\end{array}$ & $\begin{array}{l}\text { Reference } \\
+5000 \mathrm{~d}\end{array}$ \\
\hline $\begin{array}{l}\text { Limited } \\
\text { access time }\end{array}$ & $\begin{array}{l}210.4 \mathrm{~cm} \\
6 \mathrm{ft} 11 \mathrm{in} .\end{array}$ & $\begin{array}{l}209.4 \mathrm{~cm} \\
6 \mathrm{ft} 11 \mathrm{in} .\end{array}$ & $\begin{array}{l}207.6 \mathrm{~cm} \\
6 \mathrm{ft} 11 \mathrm{in} .\end{array}$ & $\begin{array}{l}205.8 \mathrm{~cm} \\
6 \mathrm{ft} 10 \mathrm{in.}\end{array}$ \\
\hline $\begin{array}{l}\text { Unlimited } \\
\text { access time }\end{array}$ & $\begin{array}{l}240.8 \mathrm{~cm} \\
7 \mathrm{ft} 11 \mathrm{in} .\end{array}$ & $\begin{array}{l}239.7 \mathrm{~cm} \\
7 \mathrm{ft} 11 \mathrm{in} .\end{array}$ & $\begin{array}{l}237.8 \mathrm{~cm} \\
7 \mathrm{ft} 10 \mathrm{in} .\end{array}$ & $\begin{array}{l}236.0 \mathrm{~cm} \\
7 \mathrm{ft} 9 \mathrm{in} .\end{array}$ \\
\hline
\end{tabular}

NOTES:

Calculated Distance is from Top of Fuel Storage Array to Water

Surface.

Dose point is $152.4 \mathrm{~cm}$ ( $5 \mathrm{ft}$ ) Air above water surface.

Situation: one canister $3 \mathrm{ft}$ above storage array.

Reference date is January 31, 1995.

'Limited access time ( 1 hour/day), calculated dose rate is $2 \mathrm{mR} / \mathrm{h}$.

'Unl imited access time, calculated dose rate is $0.2 \mathrm{mR} / \mathrm{h}$.

The current operational limit of three canisters per storage bay out of storage and on hoists will not be affected.

Figure 2 is a graph of the ISOSHLD-II calculated dose rate due to an irradiated fuel storage array with one canister suspended $91.44 \mathrm{~cm}(3 \mathrm{ft})$ above the rest of the array as a function of water shielding thickness above the fuel storage array. The $91.44-\mathrm{cm}(3-\mathrm{ft})$ distance is measured from the top of the lid in the canister array to the top of the lid of the suspended canister. A canister is $73.66 \mathrm{~cm}$ (29 in.) high; this allows $17.78 \mathrm{~cm}(7$ in.) between the bottom of the suspended canister and the top of the canisters in the canister array. This models the situation of lifting one canister above the storage array in order to move it to another location. A $152.4-\mathrm{cm}(5-\mathrm{ft})$ air shield is above the water surface to the calculated dose point. 
Figure 1. Basin Water Shielding Geometry. (Single Canister $91.44 \mathrm{~cm}$ (3 ft) Above Triple-Stacked Array.)

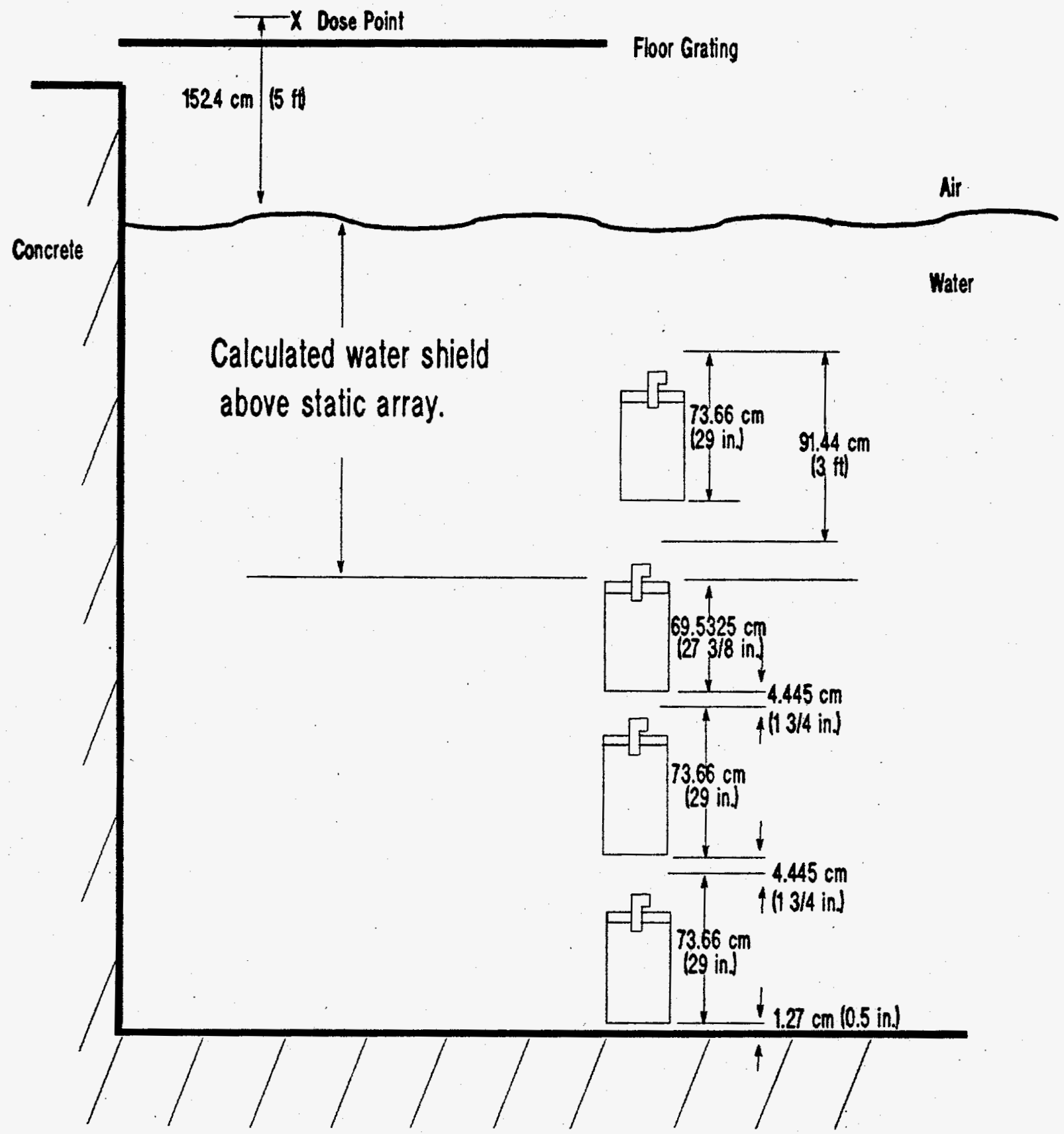

Active basin shielding calculations allowed for a single canister $91.44 \mathrm{~cm}$ $(3 \mathrm{ft}$ ) above the static canister array. Dose point is calculated $152.4 \mathrm{~cm}$ $(5 \mathrm{ft})$ above water surface. 


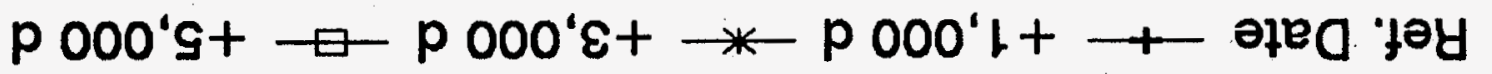

这

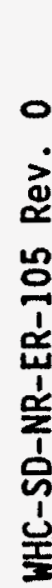

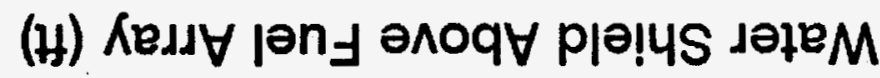

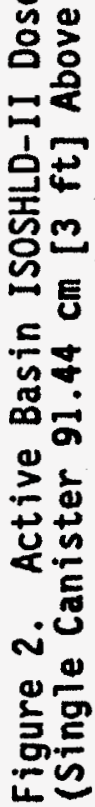

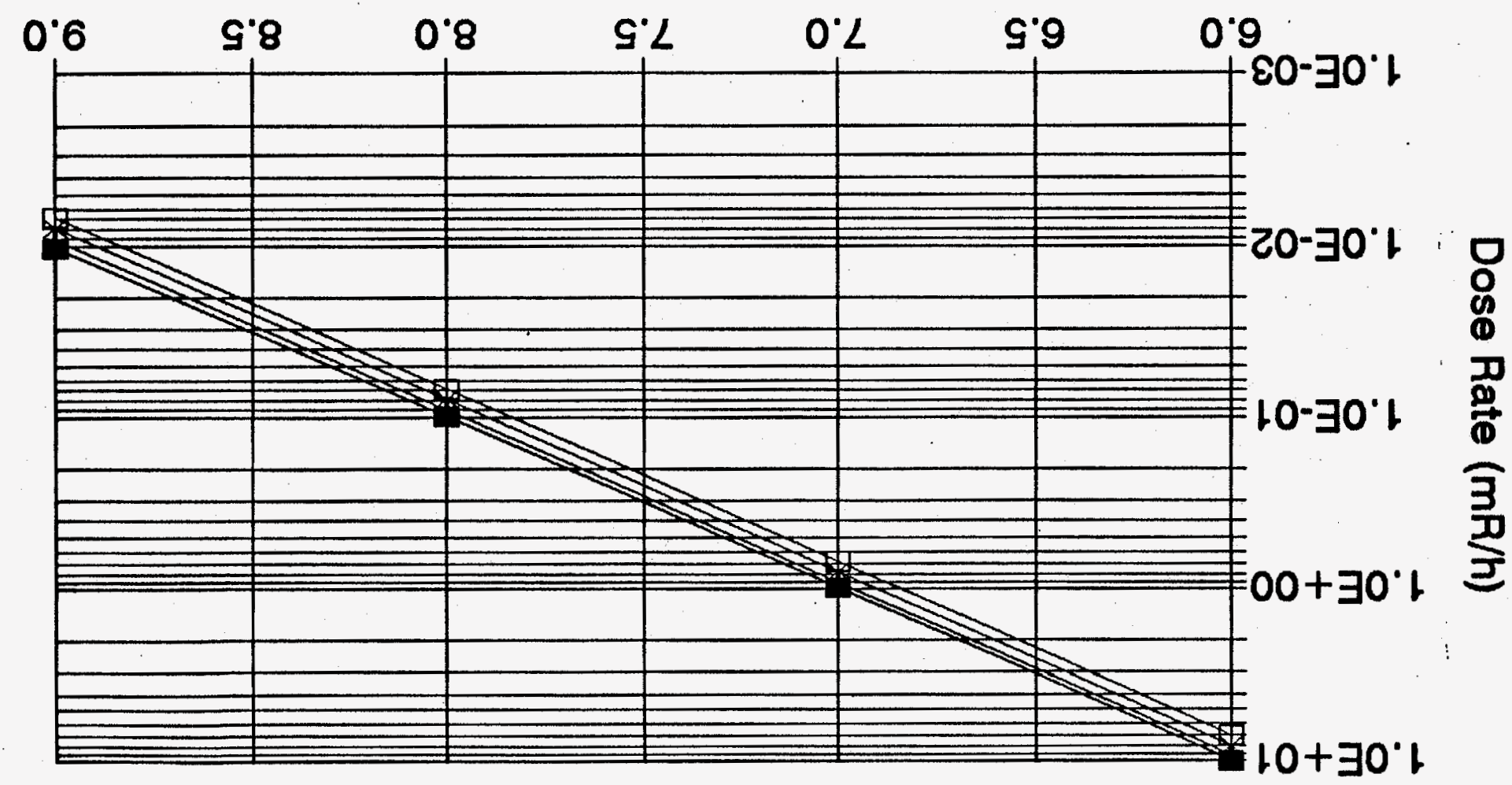


Figure 3 is a graph of ISOSHLD-II calculated dose rate due to an irradiated fuel storage array as a function of water shielding thickness above the fuel storage array. This models the situation of a static fuel storage array without any canister lifted above the fuel storage array. A 152.4-cm $(5-\mathrm{ft})$ air shield is above the water surface to the calculated dose point.

\subsection{METHOD}

Dose rate calculations were performed for irradiated $N$ Reactor fuel, and some single-pass reactor (SPR) fuel, presently (July 1994) stored in the 105-KE and 105-KW Basins. The calculation of dose rate incorporated the following elements:

1. Measurement of gamma dose rate on individual canisters

2. ISOSHLD-II model dose rate calculations consistent with these single canister measurements on canister sides (Wittekind 1988b)

3. Conversion of ISOSHLD-II canister side model to a canister top model

4. Extension of the ISOSHLD-II canister top model to a canister storage location model

5. Accommodation of highest dose rate canister in the fuel storage basin from the ISOSHLD-II canister models compared to measured dose rates

6. Expansion of the ISOSHLD-II single canister storage location model to a full-basin geometry (Wittekind 1991)

7. Combination of ISOSHLD-II full-basin results with single canister results to model single canister movement over fuel storage array

8. Consideration of additional irradiated fuel storage canisters in motion simultaneously

9. Interpolation of calculated ISOSHLD-II dose rate results for radiation shield design requirements to determine minimum design water shield thickness requirements

10. Comparison with other ISOSHLD versions and acceptance of a justifiable and conservative dose rate calculation.

The dose rate calculations began with establishing an ISOSHLD-II model that would match measured dose rates. These measurements were performed on canisters from $N$ Reactor discharges that averaged 6 wt\% $240 \mathrm{Pu}$ and $12 \mathrm{wt} \%$ ${ }^{240} \mathrm{Pu}$ irradiated fuel at decay times after the end of irradiation between 549 days and 5,900 days. The measurements were taken on the side of the canister, and $30.48 \mathrm{~cm}(1 \mathrm{ft})$ of water shielding away from the side of the canister. Thickness of the detector and its PVC tube holder were not considered in the ISOSHLD-II model of the experimental measurements. 
కั

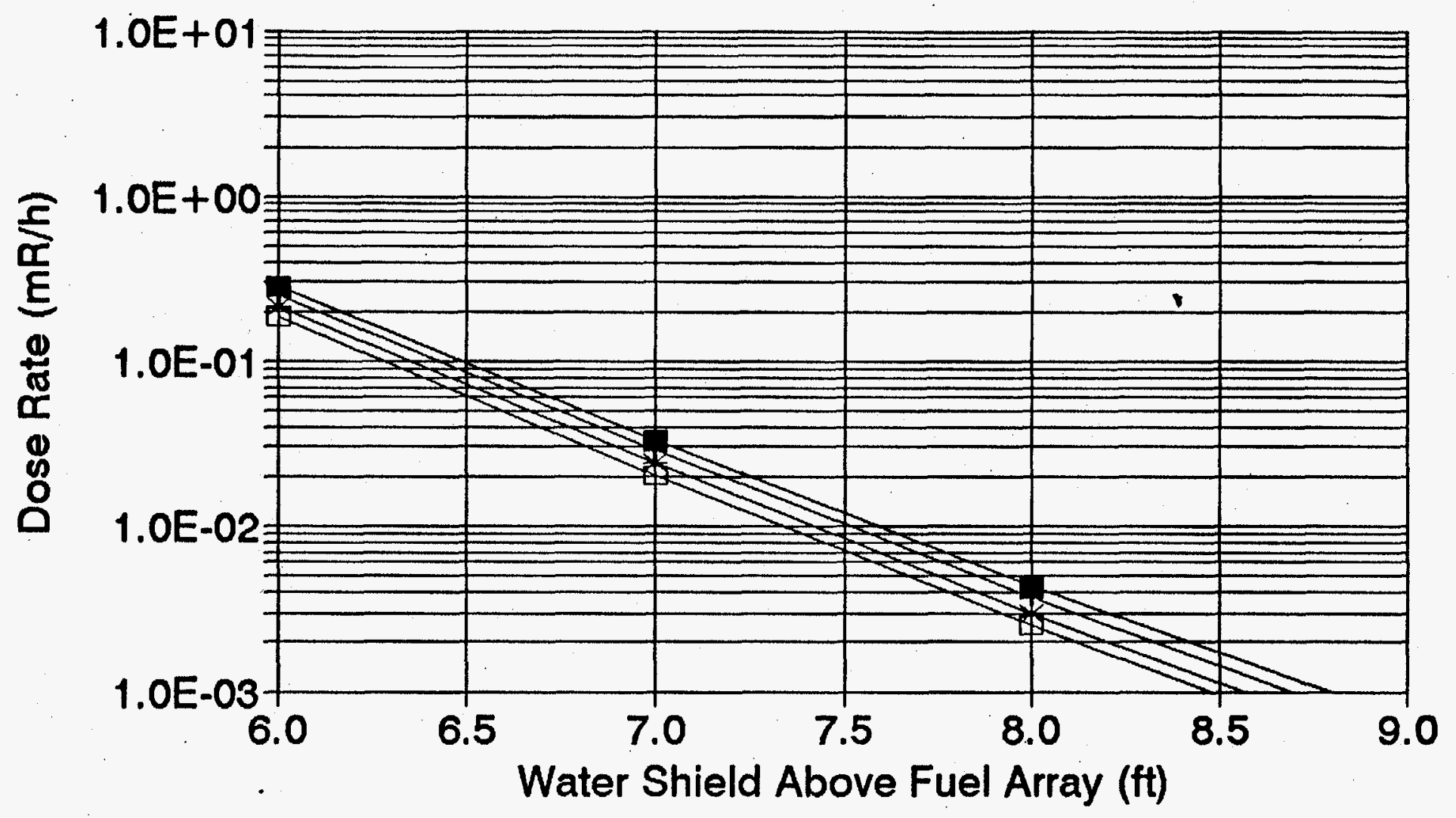

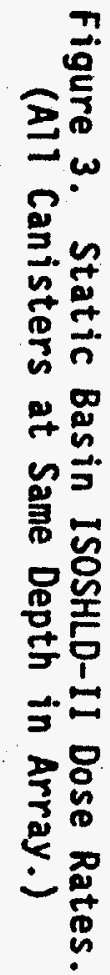

$\rightarrow-$ Ref. Date $\longrightarrow+1,000 d \rightarrow+3,000 d-\square+5,000 d$ 
The effect of 1 in. air attenuation was considered to be small and was neglected. Two additional measurements did not fit into this pattern: a measurement taken on the opposite canister barrel, and a canister dose rate measured on the lid. The measurement on the canister lid is most relevant to the dose rate above an irradiated fuel storage array.

The $\mathbf{N}$ Reactor fuel elements have a tube-in-tube geometry. There is an outer fuel cylinder and an inner fuel cylinder with a cooling hole down the center. This geometry indicates that the ISOSHLD-II model in the horizontal direction can reasonably homogenize the fuel element, zirconium, and water. This geometry also indicates that the ISOSHLD-II model in the vertical direction should not homogenize the fuel element, but rather model the fuel element as uranium, or even as uranium with a zirconium end cap. The ISOSHLD-II canister side model established the fission product gamma ray source as reasonable in magnitude and confirmed the use of the water shield for the dominant shield buildup factor for determining the deep-penetrating gamma rays at $30.48 \mathrm{~cm}(1 \mathrm{ft}$ ) (and greater) water shield thickness. The buildup factor accommodates the attenuation of gamma rays by absorption and by scattering. Scattered gamma rays may decrease in energy, but still contribute to the dose rate. Gamma ray scattering without absorption is accounted for by multiplying by a buildup factor. A dominant gamma ray shield must be chosen for the ISOSHLD-II calculation. At a water shield thickness of $30.48 \mathrm{~cm}$ (l ft) or greater, the dominant shield is, or course, water. At canister contact, the dominant shield is the canister contents.

The ISOSHLD-II canister side model using the side of a cylinder geometry was converted to an ISOSHLD-II canister top model. The geometry was changed from the side of a cylinder to the end of a cylinder, and the homogenized canister contents were changed to pure uranium at uranium metal density. The fission product source term remained the same and the water shield buildup factor remained the same for the ISOSHLD-II canister side and canister top models.

The ISOSHLD-II canister top model was converted to a canister storage location geometry by changing from an end cylinder geometry to a rectangular geometry. A few ISOSHLD-II models were calculated to move from the end cylinder single canister model to the canister storage location rectangular model.

Another consideration was the exposure of the highest dose rate $N$ Reactor fuel in either 105-KE or 105-KW Basin. The highest exposure $N$ Reactor fuel is slightly over $16 \mathrm{wt} \%{ }^{240} \mathrm{Pu}$ with a certain decay time. The shortest decay time has a lower exposure. The limiting storage basin will be composed of the highest dose rate canisters. Both situations were calculated by ISOSHLD-II with the result that the highest exposure case had the greatest calculated dose rate. The highest exposure situation was used for all subsequent calculations because this calculated the highest calculated dose rate.

The ISOSHLD-II canister storage location model was expanded to a static basin geometry by increasing the total power generated in the source region and increasing from single canister storage location rectangular geometry to a 1,800 canister storage location basin. Several ISOSHLD-II models were calculated to move from the single canister location model to the static fuel storage array rectangular model. Only the top layer of the canister array 
contributes to the dose rate at the calculated dose point so lower layers in the triple-stacked canister storage array do not have to be considered in the ISOSHLD-II calculation.

The irradiated fuel storage basin activities involve movement of canisters out of position and ifted above the fuel storage array in order to relocate the canisters. This is the active fuel storage array with one canister $91.44 \mathrm{~cm}$ (3 ft) (canister height is $73.66 \mathrm{~cm}$ [29 in.]) above the static fuel storage array. ISOSHLD-II calculated dose results added the results for a static fuel storage array and the results for one canister with $91.44 \mathrm{~cm}$ (3 ft) less water shielding. The largest contribution to the active fuel storage array is due to this single canister $91.44 \mathrm{~cm}(3 \mathrm{ft})$ above the static fuel storage array. The shielding effect of the raised canister above the nearest canister in the fuel storage array was neglected.

Consideration of other nearby canisters lifted and in motion simultaneously was done by using the ISOSHLD-II results and accommodating additional distance dispersion and increase radiation attenuation. For nearby additional raised canisters, there is a small increase in calculated radiation dose rate. There is no proposal for limiting the number of lifted canisters in the irradiated fuel storage basins.

The dose rate of $0.2 \mathrm{mR} / \mathrm{h}$ (maximum $0.5 \mathrm{mR} / \mathrm{h}$ ) is the initial design level dose rate for unlimited access (WHC-CM-4-9). The dose rate of $2.0 \mathrm{mR} / \mathrm{h}$ ( $5.0 \mathrm{mR} / \mathrm{h}$ maximum) is the initial design level dose rate for 1 imited access time situation, or 1 hour per day (WHC-CM-4-9). The interpolated water shielding thickness which resulted in these gamma ray dose rates became the minimum water thickness required above the irradiated fuel storage array. At this time after fuel discharge, there is very little change in radiation shielding requirements with additional decay time. There is only a small decrease of radiation shielding requirements with additional decay time after January 31, 1995. Radiation shielding requirements are dominated by the 30.17-year half-life of ${ }^{137} \mathrm{Cs}$.

Extrapolation of contact and $30.48-\mathrm{cm}(1-\mathrm{ft})$ water shield thickness measurements to the $152.40-\mathrm{cm}(5-\mathrm{ft})$ and $243.84-\mathrm{cm}(8-\mathrm{ft})$ water shield thickness ISOSHLD-II dose rate calculations was checked by comparison with other ISOSHLD versions. ISOSHLD 4.0 results were accepted based on greater consistency with experimental measurements in 105-KW Basin. This is justifiable and assures a conservative calculation of dose rates. This caused an additional water shield thickness to be added to the ISOSHLD-II dose rate calculations to account for. an indicated nonconservative dose rate calculation bias in ISOSHLD-II. 


\subsection{DISCUSSION}

This section discusses comparison to irradiated fuel canister dose rate measurements, the ISOSHLD-II model and extension of the ISOSHLD-II model to, ultimately, an active (one canister in motion above the static array) fuel storage basin model with inference to a design minimum water shield thickness.

\subsection{CANISTER DOSE RATE MEASUREMENTS}

A gamma probe, with a stated accuracy of $\pm 10 \%$ and a readout dial with smallest increment of $10 \mathrm{R} / \mathrm{h}$ on the $20,000 \mathrm{R} / \mathrm{h}$ scale used, was placed inside a PVC tube that was closed and weighted at one end. This PVC tube had a smaller, I-ft-long tube sticking off to one side. This smaller tube was used as a fixed $1-f t$ distance measure. In this manner, a measurement could be made at contact and at 1-ft away from the canister side in water. The gamma ray dose rate measurements (Wittekind 1988b) were observed, and a simple tworegion ISOSHLD-II model was documented. The goal was to simulate these measurements, and to apply them to situations that were not measured because of expected high radiation dose rates.

The canisters that had their gamma dose rate measured contained Mark IA (MKIA) style fuel and Mark IV (MKIV) style N Reactor fuel, with stated exposures of $6 \mathrm{wt} \%$ and $12 \mathrm{wt} \%{ }^{240} \mathrm{Pu}$, and decay times between 549 days and 5,900 days. For simplicity in the following calculations, both MKIV and MKIA fuel was considered to be MKIV fuel. This is reasonable because MKIV and MKIA are similar. This is also conservative because this document's application will be for the gamma ray dose out of the top of the canister where the MKIV fuel, because of its longer length and consequently less vertical shielding, results in the larger gamma ray dose.

of course the designation of $6 w t \%{ }^{240} \mathrm{Pu}$ and $12 w t \%{ }^{240} \mathrm{Pu}$ actually refers to fuel elements with a distribution of exposure that is, hopefully, centered on the $6 \mathrm{wt} \%{ }^{240} \mathrm{Pu}$ and $12 \mathrm{wt} \%{ }^{240} \mathrm{Pu}$. The scatter in the dose rate measurements can easily be ascribed to this variation in the exposure of the fuel elements which happened to be closest to the gamma probe.

For simplicity in the following calculations, the measured gamma dose rate for 12 wt\% $240 \mathrm{Pu}$ exposure canisters were divided in half and considered to be a 6 wt\% ${ }^{240} \mathrm{Pu}$ exposure canister. This is not entirely accurate, but is consistent with the accuracy of the canister dose rate measurements.

Similarly, scaling to 16 wt\% $240 \mathrm{pu}$ exposure canisters could be accomplished by multiplying the 6 wt\% ${ }^{240} \mathrm{Pu}$ dose rate by 2.67 . When the irradiation effect is calculated in Section 2.4.3, the scaling is performed more accurately, but for the purpose of comparing to experimental measurements, this scaling is reasonable.

Canister dimensions and compositions were derived from drawings $\mathrm{H}-\mathrm{l}-36935$, $\mathrm{H}-1-42793$, and $\mathrm{H}-1-46215$. 


\subsection{CANISTER SIDE ISOSHLD-II MODELS}

The 1988 ISOSHLD-II model (Wittekind 1988b) was matched to the dose rate measurements at contact. This homogenized canister contents ISOSHLD-II modeI was then considered appropriate for both the contact and the 1-ft water shielding situation. The canister contact measurement was modeled with the radiation shielding buildup factor for the homogenized canister contents, which included some water. Slight variations off of the 1988 base model included ignoring water in the homogenized canister contents, using the water buildup factor instead of the homogenized canister contents buildup factor, and solid uranium as the homogenized canister contents, also with the two different buildup factors. These various two-region models are detailed in Table 2.

Table 2. Two-Region Canister Side ISOSHLD-II Models.

\begin{tabular}{|l|c|c|c|c|c|}
\hline $\begin{array}{c}\text { Homogenized } \\
\text { canister contents }\end{array}$ & $\begin{array}{c}1988 \\
\text { base mode1 }\end{array}$ & Model \#2 & Model \#3 & Model \#4 & Model \#5 \\
\hline Uranium $\left(\mathrm{g} / \mathrm{cm}^{3}\right)$ & 7.3876 & 7.3876 & 7.3876 & 18.63 & 18.63 \\
\hline Zirconium $\left(\mathrm{g} / \mathrm{cm}^{3}\right)$ & 0.5077 & 0.5077 & 0.5077 & 0.00 & 0.00 \\
\hline Water $\left(\mathrm{g} / \mathrm{cm}^{3}\right)$ & 0.5300 & 0.0000 & 0.5300 & 0.00 & 0.00 \\
\hline $\begin{array}{l}\text { Buildup factor } \\
\text { for shield }\end{array}$ & $\begin{array}{c}\text { Canister } \\
\text { contents }\end{array}$ & $\begin{array}{c}\text { Canister } \\
\text { contents }\end{array}$ & Water & Canister & $\begin{array}{c}\text { Water } \\
\text { contents }\end{array}$ \\
\hline
\end{tabular}

NOTES: Canister size: $10.3251 \mathrm{~cm}$ radius (8.13 in. 0.D.).

Fuel height: $66.294 \mathrm{~cm}(26.1 \mathrm{in.})$.

ISOSHLD-II calculations were performed for the end of irradiation and at 500 days, 1,000 days, 3,000 days and 5,000 days decay after the end of irradiation. The physical phenomena of radioactive decay obeys the relation:

$$
N(t)=N(t=0) \exp (-\lambda t)=N(t=0) \exp \left(-\left(\ln (2) / t_{y_{2}}\right) t\right)
$$

where:

$N(t)=$ Number of atoms at time $t$.

$\lambda=$ Radioactive decay constant.

$\ln (2)=$ Natural logarithm of 2 .

$t_{y_{2}}=$ Radioactive half-life.

The physical basis indicates that the natural logarithm of dose rate, which is proportional to the natural logarithm of the number of atoms, is proportional to decay time. Actually, the dose rate would be proportional to the sum of a number of exponentials, one for each significant isotope contributor, but at the decay times being considered, only ${ }^{137} \mathrm{Cs}$ is important as long as the end of irradiation ISOSHLD-II calculated result is not used. The natural logarithm of the ISOSHLD-II dose rate results were interpolated by 
linear interpolation, using one time on one side and the other time on the other side of the decay time being interpolated, if available, otherwise the closest two ISOSHLD-II calculated times were used.

Table 3 lists the ISOSHLD-II calculated dose rates for irradiated fuel at discharge and the four specific subsequent decay times. Linear interpolation is performed to determine the ISOSHLD-II result for the decay times of the experimental measurements. The measured dose rates close to 6 wt\% ${ }^{240} \mathrm{Pu}$ exposure are shown in the middle of Table 3. Finally, on the right hand side in Table 3, the ISOSHLD-II calculated result is divided by the experimental measurement.

The average of the calculated-to-measured ratio is used as the figure of merit for different ISOSHLD-II models. The homogenized canister contents model, 1988 base case, has the calculated-to-measured ratio closest to 1.0 for the canister contact measurements. For the 1-ft water shield thickness, the buildup factor for the water shield is the most appropriate ISOSHLD-II model. The ISOSHLD-II calculated results for contact geometry averaged 1.0792 (see Table 3), or about $8 \%$ high, so some modification is possible. An average result close to 1.0 was the desired result for ISOSHLD-II calculations divided by experimental measurements.

The 1988 ISOSHLD-II model was improved by explicitly including the canister barrel. This increased the number of regions from two to three and slightly reduced the homogenized canister contents radius. Accountability personnel attempted to determine whether the canisters used for experimental measurements were aluminum or stainless steel. Most of the experimentaliy measured canisters were stainless steel (see Appendix B). The two-region and three-region ISOSHLD-II models are depicted in Figure 4. A more detailed description of the three-region model is in Table 4.

The dose rate calculated by ISOSHLD-II for the canister side at contact was reduced about $12 \%$ in the three-region mode1, but because the dose rates calculated previousiy for the two-region ISOSHLD-II model were approximately $8 \%$ too high, the improved model is more consistent with experimental measurements on the canister side at contact. The 1988 ISOSHLD-II model calculated only the canister side at contact dose rate measurements. The three-region ISOSHLD-II model was applied to both the canister side contact dose rate measurements and the 1-ft distance dose rate measurements. The three-region canister side at contact ISOSHLD-II model used the homogenized canister contents for the dose rate buildup factor. The three-region canister side at $1 \mathrm{ft}$ distance ISOSHLD-II model used water shield for the dose rate buildup factor. This is the only difference between the canister side at contact and the canister side at $1 \mathrm{ft}$ distance ISOSHLD-II models.

The explanation of Table 5 is the same as the description for Table 3 , except that the three-region ISOSHLD-II canister side model was calculated rather than the two-region ISOSHLD-II canister side model. The logarithm of ISOSHLD-II calculated results, were, using four different decay times after irradiation, lineariy interpolated to the decay time of the measurement canisters. The average ratio of ISOSHLD-II interpolated dose rates for the eight canister measurements was calculated. An average result close to 1.0 was the desired result for ISOSHLD-II calculations divided by experimental measurements. 
Table 3. Two Region Canister Side ISOSHLD-II Dose Rates. (2 sheets)

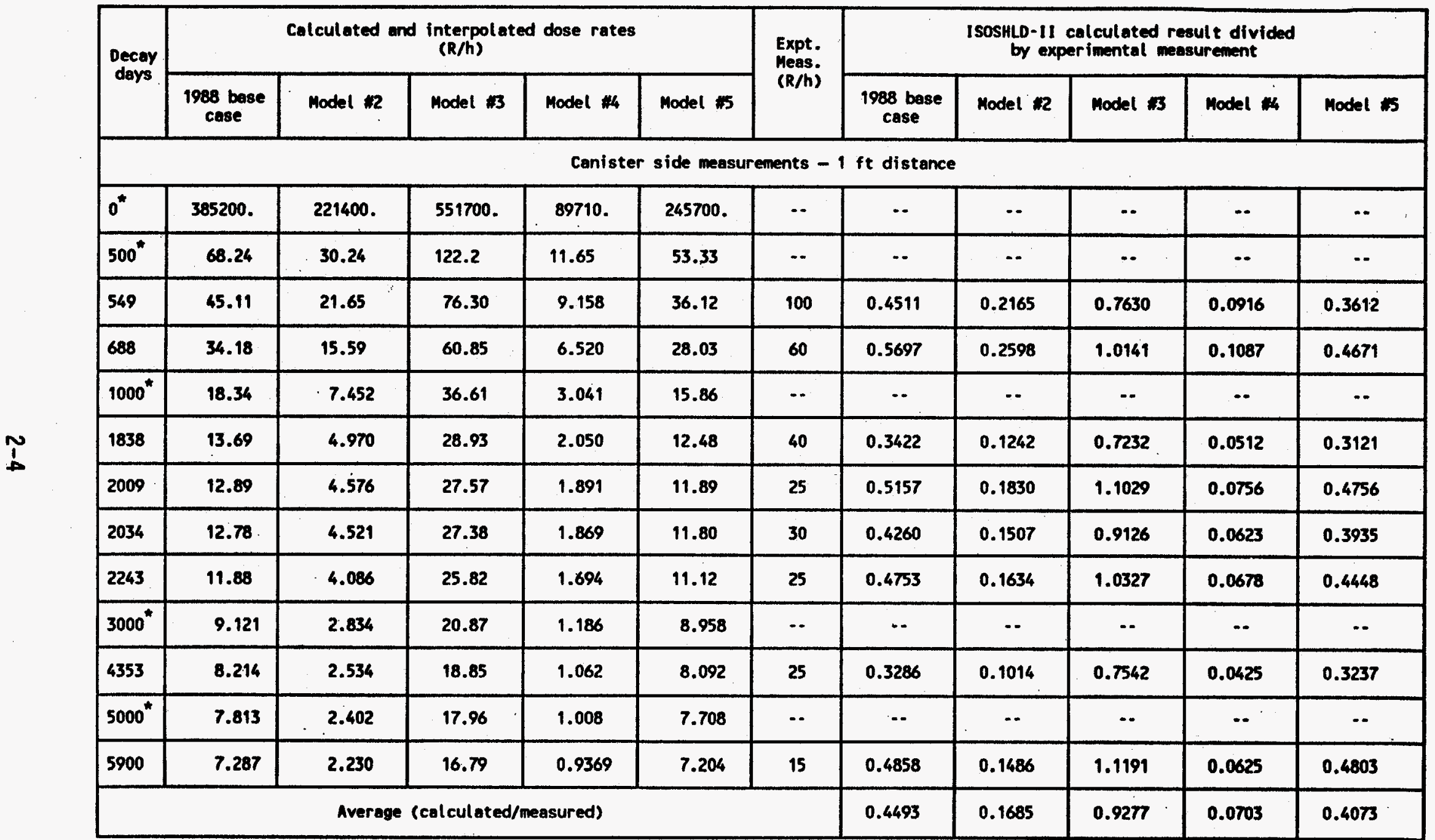


Table 3. Two Region Canister Side ISOSHLD-II Dose Rates. (2 sheets)

\begin{tabular}{|c|c|c|c|c|c|c|c|c|c|c|c|}
\hline \multirow{2}{*}{$\begin{array}{l}\text { Decay } \\
\text { days }\end{array}$} & \multicolumn{5}{|c|}{$\begin{array}{l}\text { Calculated and interpolated dose rates } \\
(R / h)\end{array}$} & \multirow{2}{*}{$\begin{array}{l}\text { Expt. } \\
\text { Meas. } \\
\text { (R/h) }\end{array}$} & \multicolumn{5}{|c|}{$\begin{array}{l}\text { 1SOSHLD- II calculated result divided } \\
\text { by experimental measurement }\end{array}$} \\
\hline & $\begin{array}{l}1988 \text { base } \\
\text { case }\end{array}$ & Model $\because 2$ & Model $\mathbf{n}$ & Model & Model $\$ 5$ & & $\begin{array}{l}1988 \text { base } \\
\text { case }\end{array}$ & Model 12 & Model 33 & Model 14 & Model is \\
\hline \multicolumn{12}{|c|}{ Canister side measurements - contact } \\
\hline $0^{*}$ & 7993000 & 5733000 & 10930000 & 2375000 & 4820000 & - & $\cdots$ & $\cdots$ & $\cdots$ & -- & $\cdots$ \\
\hline $500^{*}$ & 2058. & 1329. & 3193. & 541.0 & 1389. & $\cdots$ & $\cdots$ & $\cdots$ & $\cdots$ & $\cdots$ & $\cdots$ \\
\hline 549 & 1818. & 1167. & 2847. & 476.6 & 1237. & 1760 & 1.0327 & 0.6630 & 1.6175 & 0.2708 & 0.7029 \\
\hline 688 & 1278. & 806.7 & 2056. & 332.6 & 890.8 & 920 & 1.3887 & 0.8769 & 2.2346 & 0.3616 & 0.9683 \\
\hline $1000^{*}$ & 579.1 & 352.3 & 990.0 & 148.4 & 426.2 & $\cdots$ & $\cdots$ & $\cdots$ & $\because$ & $\cdots$ & $\cdots$ \\
\hline 1838 & 461.4 & 273.3 & 805.9 & 114.8 & 345.6 & 510 & 0.9047 & 0.5359 & 1.5802 & 0.2251 & 0.6776 \\
\hline 2009 & 440.5 & 259.5 & 772.8 & 108.9 & 331.1 & 300 & 1.4683 & 0.8650 & 2.5759 & 0.3631 & 1.1037 \\
\hline 2034 & 437.5 & 257.5 & 768.1 & 108.1 & 329.0 & 475 & 0.9211 & 0.5422 & 1.6170 & 0.2275 & 0.6927 \\
\hline 2243 & 413.4. & 241.7 & 729.6 & 101.4 & 312.3 & 400 & 1.0335 & 0.6044 & 1.8241 & 0.2534 & 0.7807 \\
\hline $3000^{\star}$ & 336.7 & $192: 2$ & 605.9 & 80.38 & 258.4 & $\cdots$ & $a$ & $\cdots$ & $\cdots$ & $-\cdot$ & $\cdots$ \\
\hline 4353 & 304.1 & 173.3 & 547.9 & 72.49 & 233.7 & 415 & 0.7327 & 0.417 & 1.3203 & 0.1747 & 0.5631 \\
\hline $5000^{\star}$ & 289.6 & 165.0 & 522.2 & 69.00 & 222.7 & $\cdots$ & $\cdots$ & $\cdots$ & $\cdots$ & -. & $\cdots$ \\
\hline 5900 & 270.6 & 154.0 & 488.4 & 64.42 & 208.3 & 235 & 1.1515 & 0.6555 & 2.0783 & 0.2741 & 0.8863 \\
\hline \multicolumn{7}{|c|}{ Average (calculated/measured) } & 1.0792 & 0.6451 & 1.8560 & 0.2688 & 0.7969 \\
\hline
\end{tabular}

-ISOSHLD-1I calculated dose rates. Other decay times were linearly interpolated using the logarithm of the dose rate (dependent variable) versus decay time (independent variable). 


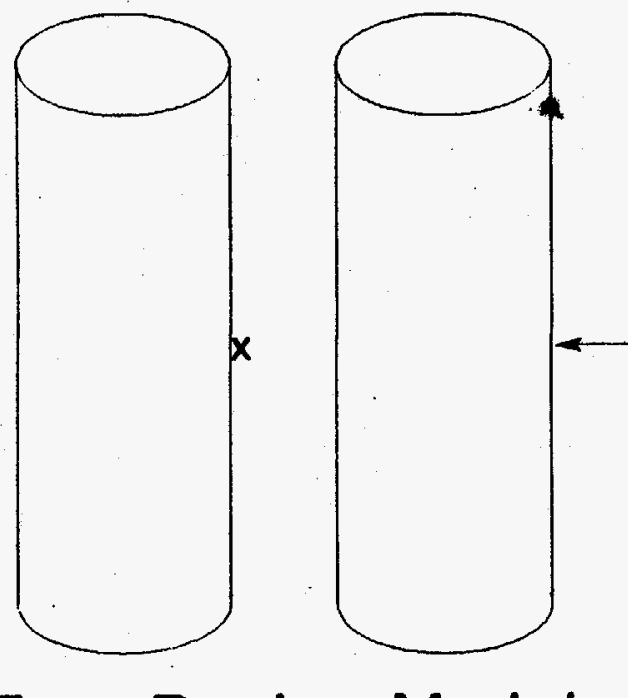

ڤั Two-Region Model

Homogenized canister contents buildup factor for contact geometry.

Water buildup factor for $30.48 \mathrm{~cm}(1 \mathrm{ft})$ distant dose point.

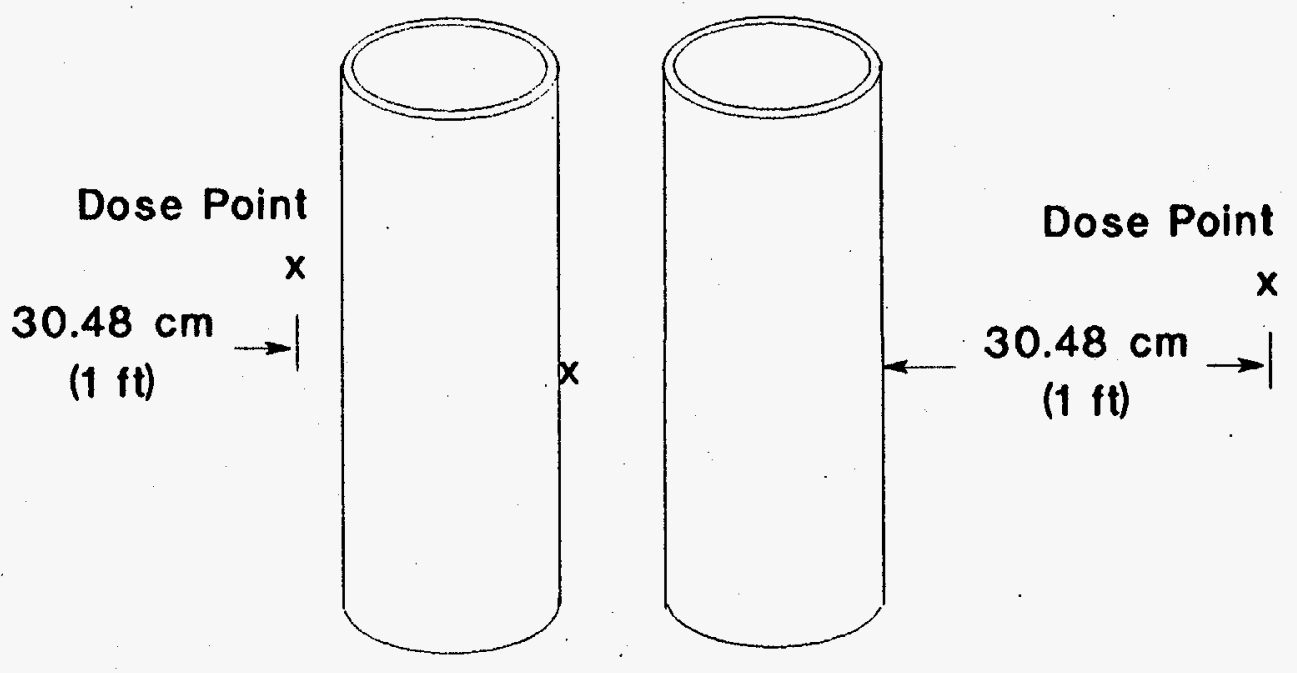

Three-Region Model.

Explicit $0.1524 \mathrm{~cm}(0.060 \mathrm{in}$.$) stainless steel canister.$

Homogenized canister contents buildup factor for contact geometry.

Water buildup factor for $30.48 \mathrm{~cm}(1 \mathrm{ft})$ distant dose point. 
Table 4. Three-Region Canister Side ISOSHLD-II Models.

\begin{tabular}{|l|c|c|c|c|c|}
\hline $\begin{array}{c}\text { Homogenized } \\
\text { canister contents }\end{array}$ & Model $\# 1 \mathrm{~A}$ & Model $\# 2 \mathrm{~A}$ & Model *3A & Model *4A & Model \#5A \\
\hline Uranium $\left(\mathrm{g} / \mathrm{cm}^{3}\right)$ & 7.3876 & 7.3876 & 7.3876 & 18.63 & 18.63 \\
\hline Zirconium $\left(\mathrm{g} / \mathrm{cm}^{3}\right)$ & 0.5077 & 0.5077 & 0.5077 & 0.00 & 0.00 \\
\hline Water $\left(\mathrm{g} / \mathrm{cm}^{3}\right)$ & 0.5300 & 0.0000 & 0.5300 & 0.00 & 0.00 \\
\hline $\begin{array}{l}\text { Buildup factor for } \\
\text { shield }\end{array}$ & $\begin{array}{l}\text { Canister } \\
\text { contents }\end{array}$ & $\begin{array}{l}\text { Canister } \\
\text { contents }\end{array}$ & Water & $\begin{array}{l}\text { Canister } \\
\text { contents }\end{array}$ & Water \\
\hline
\end{tabular}

NOTES: Canister size: $10.254 \mathrm{~cm}$ radius (8.074 in. 0.D.). Canister barrel thickness: $0.1524 \mathrm{~cm}(0.060 \mathrm{in}$.$) .$

Fuel height: $66.294 \mathrm{~cm} \cdot(26.1 \mathrm{in.})$.

The three-region model with homogenized canister contents is the ISOSHLD-II side model that will be used. The buildup factor for homogenized canister contents is used for contact geometry, but the water shield buildup factor will be used for the l-ft water shield thickness measurements.

The main conclusion to be drawn from the results calculated by ISOSHLD-II is that the irradiation that created the gamma ray source term is very reasonable. This canister side ISOSHLD-II model fixed the Mode 1 irradiation calculation to calculate a realistic quantity of fission products. Mode 1 is the computer code input option that ISOSHLD-II is coupled to the RIBD (RadioIsotope Buildup and Decay) code to generate a gamma ray source from irradiation parameters and decay times to compute fission product inventories. That the fission product quantity is realistic is supported by reference to the dose rate experimental measurements (Wittekind 1988b). This same source term is also used in the canister top ISOSHLD-II model.

There is a small lack of precision in comparing the basin dose rate measurements to dose rates calculated by ISOSHLD-II because the detector was about in. in radius and centered in the $6.013-\mathrm{cm}(2.3675-\mathrm{in}$.) outside diameter PVC tube by a lucite or polyethylene ring. In addition, there should have been about 1 in. air shield in the ISOSHLD-II modeled geometry for contact and the $30.48 \mathrm{~cm}(1 \mathrm{ft})$ distant measurements, but 1 in. air attenuation is considered a small effect in the basin dose rate measurements.

The final choice of ISOSHLD-II model for dose rate calculations on the side is the three-region model with homogenized canister contents, models \#1A and $\# 3 A$. The contact dose rate measurements were compared to model \#1A (canister contents shield buildup factor), yet the $1 \mathrm{ft}$ distance measurements were compared to model \#3A (water shield buildup factor). The $1 \mathrm{ft}$ water shielding situation used the radiation shielding buildup factor for water. 
Table 5. Three-Region Canister Side ISOSHLD-II Dose Rates. (2 sheets)

\begin{tabular}{|c|c|c|c|c|c|c|c|c|c|c|c|}
\hline \multirow{2}{*}{$\begin{array}{l}\text { Decay } \\
\text { days }\end{array}$} & \multicolumn{5}{|c|}{$\begin{array}{l}\text { Calculated and interpolated dose rates } \\
\qquad(R / h)\end{array}$} & \multirow{2}{*}{$\begin{array}{l}\text { Expt. } \\
\text { meas. } \\
\text { (R/h) }\end{array}$} & \multicolumn{5}{|c|}{$\begin{array}{l}\text { ISOSHLD-II calculated result divided } \\
\text { by experimental measurement }\end{array}$} \\
\hline & Model $\because 1 A$ & Model $: 2 A$ & Model $\mathbf{B A}$ & Model $\#$ A & Model MAA & & Model $* 1 A$ & Model $12 A$ & Model $13 A$ & Model Wha & Model isA \\
\hline \multicolumn{12}{|c|}{ Canister side measurements - 1 ft distance } \\
\hline $0^{*}$ & 280300 & 158900 & 399600 & 64090 & 177700. & $\cdots$ & -. & -. & $\cdots$ & $\cdots$ & -. \\
\hline $500^{*}$ & 46.57 & 20.24 & 83.43 & 7.756 & 36.36 & -. & -. & $\cdots$ & $\cdots$ & $\cdots$ & $\cdots$ \\
\hline 549 & 31.96 & 15.07 & 54.08 & 6.345 & 25.57 & 100 & 0.3196 & 0.1507 & 0.5408 & 0.0635 & 0.2557 \\
\hline 688 & 23.85 & 10.70 & 42.43 & 4.455 & 19.52 & 60 & 0.3976 & 0.1784 & 0.7071 & 0.0742 & 0.3253 \\
\hline $1000^{*}$ & 12.37 & 4.964 & 24.61 & 2.014 & 10.65 & $\cdots$ & $\cdots$ & $\cdots$ & $\cdots$ & -- & -. \\
\hline 1838 & 9.060 & 3.196 & 19.24 & 1.313 & 8.298 & 40 & 0.2265 & 0.0799 & 0.4811 & 0.0328 & 0.2075 \\
\hline 2009 & 8.502 & 2.921 & 18.30 & 1.203 & 7.886 & 25 & 0.3401 & 0.1168 & 0.7320 & 0.0481 & 0.3154 \\
\hline 2034 & 8.424 & 2.883 & 18.17 & 1.188 & 7.828 & 30 & 0.2808 & 0.0961 & 0.6055 & 0.0396 & 0.2609 \\
\hline 2243 & 7.794 & 2.583 & 17.08 & 1.067 & 7.355 & 25 & 0.3118 & 0.1033 & 0.6834 & 0.0427 & 0.2942 \\
\hline $3000^{\star}$ & 5.883 & 1.735 & 13.68 & 0.7250 & 5.871 & -. & $\cdots$ & $\cdots$ & $\cdots$ & -. & $\cdots$ \\
\hline 4353 & 5.293 & 1.548 & 12.36 & 0.6483 & 5.301 & 25 & 0.2117 & 0.0619 & 0.4943 & 0.0259 & 0.2120 \\
\hline $5000^{\star}$ & 5.032 & 1.466 & 11.77 & 0.6145 & 5.048 & $\cdots$ & $\cdots$ & $\cdots$ & $\cdots$ & $\cdots$ & -. \\
\hline 5900 & 4.690 & 1.359 & 11.00 & 0.5704 & 4.716 & 15 & 0.3127 & 0.0906 & 0.7333 & 0.0380 & 0.3144 \\
\hline \multicolumn{7}{|c|}{ Average (calculated/measured) } & 0.3001 & 0.1097 & 0.6222 & 0.0456 & 0.2732 \\
\hline
\end{tabular}


Table 5. Three-Region Canister Side ISOSHLD-II Dose Rates. (2 sheets)

\begin{tabular}{|c|c|c|c|c|c|c|c|c|c|c|c|}
\hline \multirow{2}{*}{$\begin{array}{l}\text { Decay } \\
\text { days }\end{array}$} & \multicolumn{5}{|c|}{$\begin{array}{c}\text { Calculated and interpolated dose rates } \\
(R / h)\end{array}$} & \multirow{2}{*}{$\begin{array}{l}\text { Expt. } \\
\text { meas. } \\
\text { (R/h) }\end{array}$} & \multicolumn{5}{|c|}{$\begin{array}{l}\text { ISOSHLD-II calculated result divided } \\
\text { by experimental measurement }\end{array}$} \\
\hline & Model $\boldsymbol{* 1 A}$ & Model $\boldsymbol{m a n}$ & Model $\mathbf{B A}$ & Model $: 4 a$ & Model $\mathbf{T S A}$ & & Model $\because 1 A$ & Model ira. & Model & Model MAn & Model $\operatorname{man}$ \\
\hline \multicolumn{12}{|c|}{ Canister Side Meosurements - Contact } \\
\hline $0^{*}$ & 7191000 . & 5017000 . & 9962000. & 2069000 . & 4398000 . & -- & -- & $\cdots$ & $\cdots$ & -- & $-\cdot$ \\
\hline $500^{*}$ & 1815. & 1122. & 2882. & 450.4 & 1252. & $-\cdot$ & -- & -- & $\cdots$ & -- & $\therefore$ \\
\hline 549 & 1602. & 983.7 & 2569. & 396.3 & 1115. & 1760 & 0.9102 & 0.5589 & 1.4697 & 0.2252 & 0.6335 \\
\hline 688 & 1124. & 677.4 & 1854. & 275.6 & 802.4 & 920 & 1.2219 & 0.7363 & 2.0157 & 0.2996 & 0.8722 \\
\hline $1000^{*}$ & 507.6 & 293.2 & 892.2 & 122.0 & 383.5 & -. & -. & $\cdots$ & $\cdots$ & $\therefore$ & $\cdots$ \\
\hline 1838 & 404.0 & 226.6 & 726.4 & 94.44 & 311.2 & 510 & 0.7922 & 0.4443 & 1.4243 & 0.1852 & 0.6103 \\
\hline 2009 & 365.6 & 215.0 & 696.5 & 89.63 & 298.3 & 300 & 1.2854 & 0.7166 & 2.3218 & 0.2988 & 0.9942 \\
\hline 2034 & 383.0 & 213.3 & 692.3 & 88.95 & 296.4 & 475 & 0.8063 & 0.4491 & 1.4574 & 0.1873 & 0.6240 \\
\hline 2243 & 361.8 & 200.0 & 657.7 & 83.44 & 281.4 & 400 & 0.9045 & 0.5001 & 1.6442 & 0.2086 & 0.7034 \\
\hline $3000^{*}$ & 294.4 & 158.5 & 546.2 & 66.21 & 233.0 & $\cdots$ & $\cdots$ & $\cdots$ & $\cdots$ & $\cdots$ & -- \\
\hline 4353 & 265.9 & 142.9 & 494.0 & 59.71 & 210.7 & 415 & 0.6406 & 0.3444 & 1.1903 & 0.1439 & 0.5077 \\
\hline $5000^{\star}$ & 253.2 & 136.0 & 470.8 & 56.83 & 200.8 & $\cdots$ & $\cdots$ & $\cdots$ & $\cdots$ & $\cdots$ & -- \\
\hline 5900 & 236.6 & 126.9 & 440.4 & 53.05 & 187.8 & 235 & 1.0068 & 0.5402 & 1.8739 & 0.2258 & 0.7992 \\
\hline \multicolumn{7}{|c|}{ Average (calculated/measured) } & 0.9460 & 0.5362 & 1.6734 & 0.2218 & 0.7180 \\
\hline
\end{tabular}

"ISOSHLO-11 calculated dose rates. Other decay times were linearly interpolated using the logarithm of the dose rate (dependent variable) versus decay time (independent variable). 
This is the only difference in the ISOSHLD-II models used to simulate the dose rate measurements on the canister side. Where there is not much water shielding, canister contents is the major radiation shield, further away, water becomes the dominant radiation shield. The water shield buildup factor was used for the ISOSHLD-II canister top model for the deep shielding calculations that form the basis for the significant result of this document.

\subsection{CANISTER TOP ISOSHLD-II MODELS}

The canister top ISOSHLD-II model was derived from the canister side ISOSHLD-II model by. changing the geometry to the end of a cylinder while retaining the same fission product gamma ray source. The ISOSHLD-II canister top models use the same irradiation exposure as the ISOSHLD-II canister side models. Different ISOSHLD-II canister side model homogenized canister contents models are compared. The end cylinder geometry included the top air space above the fuel and the $z$-in. stainless steel lid in the shielding geometry for a four-region model.

A single canister top dose rate measurement (Wittekind 1988b) was compared to the canister top ISOSHLD-II dose rate calculations. The fourregion end cylinder geometry with the same materials as the cylinder side geometry was compared to the one experimental measurement. The different ISOSHLD-II four-region canister top models are compared to the experimental measurement in Table 6 . The result was that the solid uranium metal as the homogenized canister contents with the canister contents buildup factor gave ISOSHLD-II dose rate calculations closest to the experimental measurement, but ISOSHLD-II calculated dose rates were quite a bit higher than the experimental measurement.

The solid uranium model for homogenized canister contents was selected as the most realistic. This change was done because of the different gamma ray shielding for vertical tube in tube fuel geometry. ISOSHLD-II calculations for an effective water thickness were varied over a range to estimate an effective experimental detector-to-lid distance. ISOSHLD-II calculated results for the selected ISOSHLD-II canister top model are reported in Table 7. Dose rates calculated by ISOSHLD-II for a four-region canister top indicated that a 1-in. distance was necessary for canister top ISOSHLD-II dose rates to be similar to the experimental measurement. This was considered to be higher than expected, so a five-region canister top ISOSHLD-II model with an explicit zirconium endcap with the same range of effective water thickness was compared to experimental measurement. The five-region ISOSHLD-II canister top model is shown in Figure 5.

The absorption of the source gamma rays in the solid uranium fuel elements is significant. Consider the representative ISOSHLD-II calculation for $152.4 \mathrm{~cm}$ ( $5 \mathrm{ft}$ ) depth and the reference decay time (Appendix $\mathrm{D}$ ). The dominant ISOSHLD-II dose comes from the 0.6500 gamma energy $(2.161 \mathrm{E}-3 / 2.566 \mathrm{E}-3$ $x 100 \%=84.22 \%)$. Other contributions are listed in Table 8 . 
Table 6. Four-Region Canister Top ISOSHLD-1I Models.

\begin{tabular}{|c|c|c|c|c|c|c|c|c|c|c|c|}
\hline \multirow{2}{*}{$\begin{array}{l}\text { Decar } \\
\text { days }\end{array}$} & \multicolumn{5}{|c|}{$\begin{array}{c}\text { Calculated and interpolated dose rates } \\
(R / h)\end{array}$} & \multirow{2}{*}{$\begin{array}{l}\text { Expt. } \\
\text { meas. } \\
\text { (R/h) }\end{array}$} & \multicolumn{5}{|c|}{$\begin{array}{l}\text { ISOSHLO-II calculated result divided } \\
\text { by experimental measurement }\end{array}$} \\
\hline & Model \#IT & Model 21 & Model $\# 3 T$ & Model $\# 4 T$ & Model $15 T$ & & Model "1r & Model $\quad 2 T$ & Model $\$ 3 T$ & Model $14 T$ & Model ist \\
\hline \multicolumn{12}{|c|}{ - Canister top Measurenent - contact } \\
\hline 0 & 9393000 . & 5976000. & 13450000. & 2544000 & 4388000 & $\because$ & $\because$ & $\ddot{-}$ & $\cdots$ & $\cdots$ & $\cdots$ \\
\hline $500^{\circ}$ & 2233. & 1192. & 3781. & 477.1 & 1000 & $\cdots$ & $\cdots$ & $\because$ & -- & $\because$ & $\cdots$ \\
\hline 549 & 1966. & 1040. & 3366. & 418.2 & 879.5 & $\because$ & $\cdots$ & -- & $\cdots$ & $\cdots$ & $-\cdot$ \\
\hline 688 & 1369. & 706.1 & 2421. & 287.8 & 611.0 & $-\cdot$ & - & $\cdots$ & $-\cdot$ & $\cdots$ & $\cdots$ \\
\hline $1000^{*}$ & 608.2 & 296.1 & 1155. & 124.4 & 269.8 & $\cdots$ & $\cdots$ & $\cdots$ & $\cdots$ & -- & $\cdots$ \\
\hline 1838 & .479 .5 & 222.1 & 938.8 & 93.31 & 211.1 & $\cdots$ & $\cdots$ & $\cdots$ & $\cdots$ & -- & $\cdots$ \\
\hline 2009 & 456.8 & 209.5 & 900.0 & 88.00 & 200.8 & 60 & 7.6128 & 3.4911 & 14.9997 & 1.4666 & 3.3463 \\
\hline 2034 & 453.5 & 207.7 & 894.4 & 87.24 & 199.3 & $\cdots$ & $\cdots$ &.- & $\cdots$ & $\cdots$ & $\cdots$ \\
\hline 2243 & 427.4 & 193.3 & 849.4 & 81.20 & 187.5 & - & - & $\cdots$ & $\cdots$ & -- & $\cdots$ \\
\hline $3000^{*}$ & 344.8 & 149.1 & 704.4 & 62.63 & 150.2 & $\cdots$ & $\therefore$ & $\cdots$ & $\cdots$ & $-\cdot$ & $\cdots$ \\
\hline 4353 & 311.2 & 134.1 & 636.9 & 56.38 & 135.5 & $\cdots$ & $\because$ & $\cdots$ & -- & $\cdots$ & $\cdots$ \\
\hline $5000^{*}$ & 296.3 & 127.5 & 607.0 & 53.62 & 129.0 & $-\cdot$ & $\cdots$ & 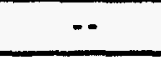 & $\cdots$ & $\cdots$ & $\cdots$ \\
\hline 5900 & 276.8 & 118.8 & 567.7 & 50.00 & 120.5 & - & $\cdots$ & $\cdots$ & $\cdots$ & $\cdots$ & $-\cdot$ \\
\hline \multicolumn{6}{|c|}{ Average (calculated/measured) } & -- & 7.6128 & 3.4911 & 14.9997 & 1.4666 & 3.3463 \\
\hline
\end{tabular}

ISOSHLD-II calculated dose rates. Other decay times were linearly interpolated using the logarithm of the dose rate (dependent variable) versus decay time (independent variable).

Four-Region Canister Top 1SOSHLD-11 Model Configuration.

\begin{tabular}{|l|c|c||l|l|l|}
\hline Fuel height: & $66.29 \mathrm{~cm}$ & $(26.1 \mathrm{in.})$ & Lid thickness: & $1.270 \mathrm{~cm}$ & $(0.50 \mathrm{in.})$ \\
\hline Air thickness: & $0.5588 \mathrm{~cm}$ & $(0.22 \mathrm{in.})$ & Hater thickness: & $0.6350 \mathrm{~cm}$ & $(0.25 \mathrm{in.})$ \\
\hline
\end{tabular}

\begin{tabular}{|c|c|c|c|c|c|}
\hline Homogenized canister contents & Model $\# 1 T$ & Model *2T & Model $\# 3 T$ & Model 41 & Model MST \\
\hline Uranium $\left(\mathrm{g} / \mathrm{cm}^{3}\right)$ & 7.388 & 7.388 & 7.388 & 18.63 & 18.63 \\
\hline Zirconium $\left(\mathrm{g} / \mathrm{cm}^{3}\right)$ & 0.5077 & 0.5077 & 0.5077 & 0.00 & 0.00 \\
\hline Water $\left(g / \mathrm{cm}^{3}\right)$ & 0.5300 & 0.0000 & 0.5300 & 0.00 & 0.00 \\
\hline Buildip factor for shield & Conister contents & Canister contents & Water & Canister contents & stainless steel \\
\hline
\end{tabular}


Table 7. Four-Region Canister Top ISOSHLD-II Dose Rates.

\begin{tabular}{|c|c|c|c|c|c|c|c|c|c|c|c|}
\hline \multirow{2}{*}{$\begin{array}{l}\text { Decay } \\
\text { days }\end{array}$} & \multicolumn{5}{|c|}{$\begin{array}{l}\text { Calculated and interpolated dose rates } \\
(R / h)\end{array}$} & \multirow{2}{*}{$\begin{array}{l}\text { Expt. } \\
\text { meas; } \\
(R / h)\end{array}$} & \multicolumn{5}{|c|}{$\begin{array}{l}\text { ISOSHLD - II calculated result divided } \\
\text { by experimental measurement }\end{array}$} \\
\hline & +y in. & Model in. & Model in. & $\begin{array}{l}+2 \text { in. } \\
\text { Model } \$ 4 t\end{array}$ & $\begin{array}{l}+3 \text { in. } \\
\text { Model }\end{array}$ & & Model in. & $\begin{array}{l}\text { +h in. } \\
\text { Model }\end{array}$ & $\begin{array}{c}+1 \text { in. } \\
\text { Model }\end{array}$ & Model in. & $\begin{array}{c}+3 \text { in. } \\
\text { Model }\end{array}$ \\
\hline \multicolumn{12}{|c|}{ Canister top measurement - contact } \\
\hline $0^{\pi}$ & 2576000 & 2335000 . & 1943000. & 1309000 & 878700 . & $-\cdot$ & $\cdots$ & -- & -- & $\cdots$ & $\cdots$ \\
\hline $500^{\prime \prime}$ & 483.4 & 436.2 & 360.1 & 237.9 & 155.5 & $\cdots$ & -- & $\cdots$ & $\cdots$ & $\because$ & $\cdots$ \\
\hline 549 & 423.8 & 382.4 & 315.7 & 208.5 & 136.3 & -- & $\because$ & $\because$ & -- & $\cdots$ & $\cdots$ \\
\hline 688 & 291.7 & 263.1 & 217.2 & .143 .4 & 93.70 & 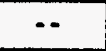 & -- & $\cdots$ & -. & $\cdots$ & 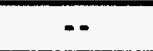 \\
\hline $1000^{\prime \prime}$ & 126.1 & 113.7 & 93.89 & 61.93 & 40.43 & -- & -- & $\cdots$ & $\because$ & $\because$ & $\cdots$ \\
\hline 1838 & .94 .57 & 85.22 & 70.26 & 46.14 & 29.93 & -- & $\because$ & $\because$ & $\because$ & $\cdots$ & $\because$ \\
\hline 2009 & 89.18 & 80.35 & 66.22 & 43.45 & 28.15 & 60 & 1.4863 & 1.3392 & 1.1037 & 0.7242 & 0.4692 \\
\hline 2034 & 88.42 & 79.67 & 65.65 & 43.07 & 27.90 & $\cdots$ & $\cdots$ & - & -- & -- & $\therefore$ \\
\hline 2243 & 82.30 & 74.14 & 61.07 & 40.02 & 25.89 & $\cdots$ & $-\cdot$ & $-\cdot$ & - & $\cdots$ & $\therefore$ \\
\hline $3000^{\prime \prime}$ & 63.46 & 57.14 & 47.00 & 30.68 & 19.73 & $\because$ & $\cdots$ & $\cdots$ & $\because$ & $\cdots$ & -- \\
\hline 4353 & 57.14 & 51.45 & 42.31 & 27.62 & 17.75 & -- & $\cdots$ & -- & $\cdots$ & $\cdots$ & $\cdots$ \\
\hline $5000^{4}$ & 54.34 & 48.93 & 40.24 & 26.26 & 16.88 & -- & $\cdots$ & -- & $\therefore$ & -- & $\cdots$ \\
\hline 5900 & 50.68 & 45.63 & 37.52 & 24.48 & 15.74 & $\cdots$ & $\cdots$ & $\cdots$ & $\cdots$ & $\cdots$ & -- \\
\hline \multicolumn{7}{|c|}{ Average (calculated/measured) } & 1.4863 & 1.3392 & 1.1037 & 0.7242 & 0.4692 \\
\hline
\end{tabular}

Isoshlo-II calculated dose rates. Other decay times were linearly interpoloted using the logarithm of the dose rate (dependent variable) versus decay time (independent variable).

Four-Region Canister Top ISOSHLD-II Model Configuration.

\begin{tabular}{|l|c|c||l|l|l|}
\hline Fuel height: & $66.29 \mathrm{~cm}$ & $(26.1 \mathrm{in.})$ & Lid thickness: & $1.270 \mathrm{~cm}$ & $(0.50 \mathrm{in})$. \\
\hline Air thickness: & $0.5588 \mathrm{~cm}$ & $(0.22 \mathrm{in.})$ & Water thickness: & Various & (Various) \\
\hline
\end{tabular}

\begin{tabular}{|c|c|c|c|c|c|}
\hline Homogenized canister contents & 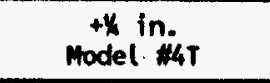 & $\begin{array}{l}+42 \text { in. } \\
\text { Model }\end{array}$ & +1 in. & $\begin{array}{l}+2 \text { in. } \\
\text { Model }\end{array}$ & model in. \\
\hline Uranium $\left(\mathrm{g} / \mathrm{cm}^{3}\right)$ & 18.63 & 18.63 & 18.63 & 18.63 & 18.63 \\
\hline 2 irconium $\left(\mathrm{g} / \mathrm{cm}^{3}\right)$ & 0.00 & 0.00 & 0.00 & 0.00 & 0.00 \\
\hline Water $\left(g / \mathrm{cm}^{3}\right)$ & 0.00 & 0.00 & 0.00 & 0.00 & 0.00 \\
\hline Buildup factor for shield & Canister contents & Canister contents & Canister contents & Canister contents & Cenister contents \\
\hline
\end{tabular}


WHC-SD-NR-ER-105 Rev. 0

Figure 5. Canister Top ISOSHLD-II Models.

(Five-Region Model Adds Explicit Endcaps.)

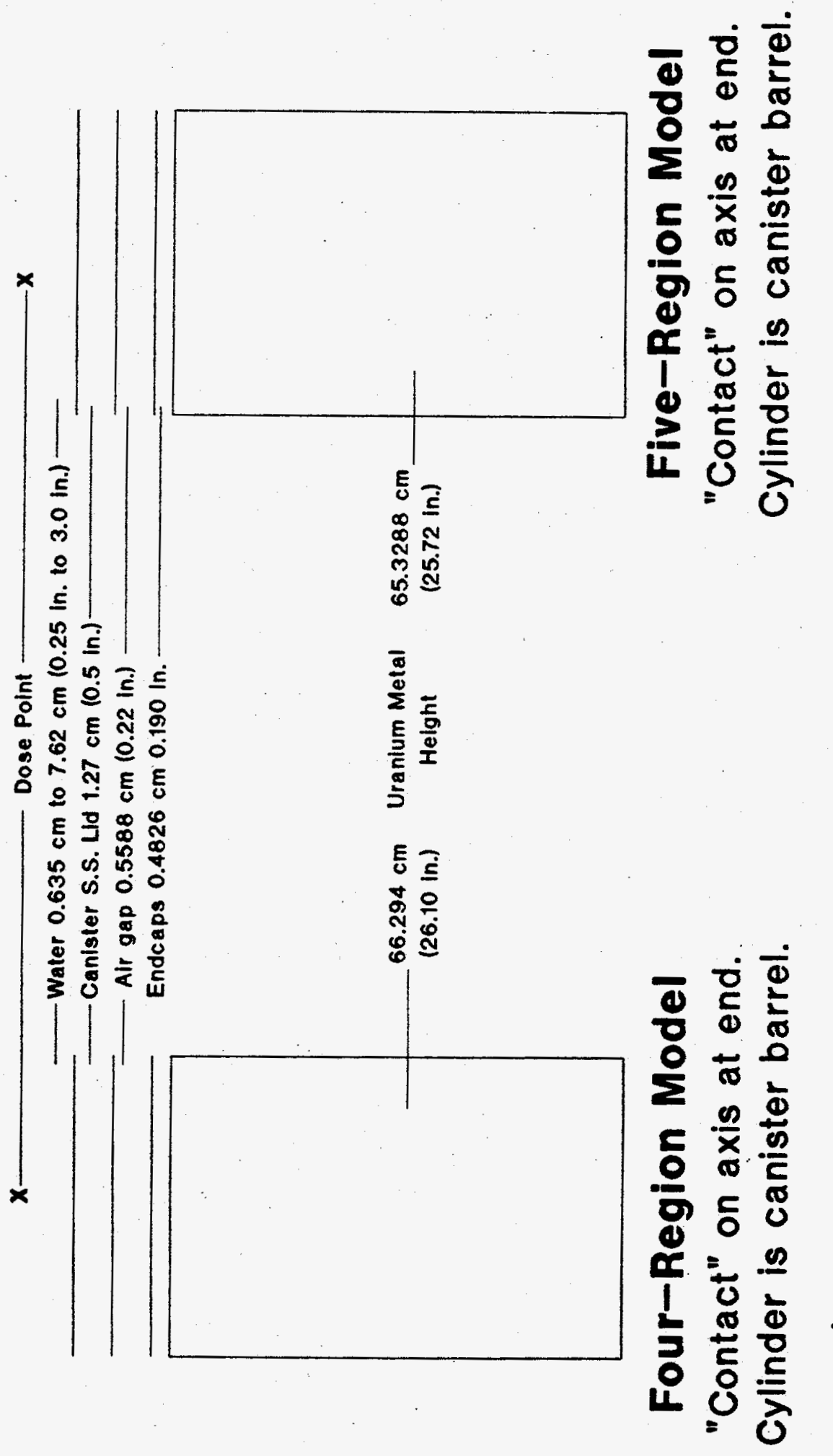


Table 8. ISOSHLD-II Gamma Ray Attenuation and Effective Penetration.

\begin{tabular}{|c|c|c|c|c|c|c|}
\hline \multirow{2}{*}{$\begin{array}{c}\text { Gamma ray } \\
\text { energy } \\
\text { (HeV) }\end{array}$} & \multirow{2}{*}{$\begin{array}{l}\text { Dose rate } \\
\text { fraction }\end{array}$} & \multirow{2}{*}{$\begin{array}{c}\text { Attenuation } \\
\text { coefficient } \\
\left(\mathrm{cm}^{-1}\right)^{\mathrm{b}}\end{array}$} & \multicolumn{2}{|c|}{$\begin{array}{c}\operatorname{Exp}(-1)= \\
0.368 \text { depth }\end{array}$} & \multicolumn{2}{|c|}{$\begin{array}{l}\operatorname{Exp}(-7)= \\
0.001 \text { depth }\end{array}$} \\
\hline & & & $\mathrm{cm}$ & in. & $\mathrm{cm}$ & in. \\
\hline 0.6500 & 0.8422 & 2.552 & 0.39 & 0.15 & 2.74 & 1.08 \\
\hline 1.2250 & 0.0669 & 1.248 & 0.80 & 0.32 & 5.61 & 2.21 \\
\hline 1.4750 & 0.0361 & 1.043 & 0.96 & 0.38 & 6.71 & 2.64 \\
\hline
\end{tabular}

NOTES: Representative results for $152.4 \mathrm{~cm}(5 \mathrm{ft})$ and reference decay date. column.

Appendix D, pages D-22 and D-23, were used to calculate second

Appendix D, pages D-9 and D-10, for uranium shield, were used to calculate column three.

c1.0/attenuation coefficient.

7.0/attenuation coefficient.

This effective depth of penetration illustrates that the dose rate contribution comes from the top end of the irradiated fuel elements. This demonstrates that the longer fuel elements (those that reach closer to the top of the canister) would calculate the highest dose rate. The Table 8 results also demonstrate that lower layers in the triple-stacked canister array will not contribute to the ISOSHLD-II calculated dose rate at the dose point.

Table 9 shows the five-region canister top ISOSHLD-II result that only one-half inch of water was required for ISOSHLD-II calculated dose rates to approximate the experimental measurement. This established the five-region canister top ISOSHLD-II model as consistent with the canister side measurements for the gamma ray source term and the one canister top measurement. Of course in the ISOSHLD-II canister top model, for thicker water shields, the water buildup factor would be used, similar to the ISOSHLD-II canister side models.

\subsection{STATIC STORAGE ARRAY ISOSHLD-II MODEL}

There are three stages in expanding from an ISOSHLD-II 6 wt\% ${ }^{240} \mathrm{Pu}$ canister top geometry into a static storage array geometry:

1. Extension of the ISOSHLD-II canister top model to a canister storage location model

2. Accommodation of highest dose rate canister in the fuel storage bas in from the ISOSHLD-II canister models compared to measured dose rates

3. Expansion of the ISOSHLD-II single canister storage location model to a full-basin geometry (Wittekind 1991). 
Table 9. Five-Region Canister Top ISOSHLD-II Dose Rates.

\begin{tabular}{|c|c|c|c|c|c|c|c|c|c|c|c|}
\hline \multirow{2}{*}{$\begin{array}{l}\text { Decay } \\
\text { days }\end{array}$} & \multicolumn{5}{|c|}{$\begin{array}{l}\text { Calculated and interpolated dose rates } \\
(R / h)\end{array}$} & \multirow{2}{*}{$\begin{array}{l}\text { Expt. } \\
\text { meas; } \\
\text { (R/h) }\end{array}$} & \multicolumn{5}{|c|}{$\begin{array}{l}\text { ISOSHLD-II calculated result divided } \\
\text { by experimental measurement }\end{array}$} \\
\hline & model in. & $\begin{array}{l}\text { +k in. } \\
\text { Model WhTA }\end{array}$ & model in. & $\begin{array}{l}+2 \text { in. } \\
\text { Model \#4TA }\end{array}$ & $\begin{array}{l}+3 \text { in. } \\
\text { Model Wita }\end{array}$ & & $\begin{array}{l}+4 \text { in. } \\
\text { Model Wira }\end{array}$ & $\begin{array}{l}\text { the in. } \\
\text { Model }\end{array}$ & $\begin{array}{l}+1 \text { in. } \\
\text { model inta }\end{array}$ & $\begin{array}{c}+2 \text { in. } \\
\text { model }\end{array}$ & Model in. \\
\hline \multicolumn{12}{|c|}{ Canister top measurement - contact } \\
\hline 0 & 2082000 & 1893000. & 1584000 & 1079000 & 731500. & $\cdots$ & $\cdots$ & $\cdots$ & $\cdots$ & -- & $\cdots$ \\
\hline $500^{\prime \prime}$ & 372.2 & 337.1 & 280.2 & 187.4 & 123.8 & $\cdots$ & $\because$ & $\cdots$ & $\cdots$ & $\cdots$ & $\cdots$ \\
\hline 549 & 325.8 & 295.1 & 245.3 & 164.0 & 108.4 & -- & -- & $\ddot{-}$ & $\because$ & $\because$ & -- \\
\hline 688 & 223.4 & 202.3 & 168.2 & 112.5 & 74.28 & $\because$ & $\cdots$ & $\cdots$ & $\because$ & $-\cdot$ & $\cdots$ \\
\hline $1000^{2}$ & 95.70 & 86.66 & 72.06 & 48.18 & 31.82 & $\cdots$ & $\cdots$ & 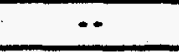 & $\because$ & $\cdots$ & $\cdots$ \\
\hline 1838 & 70.75 & 64.01 & 53.16 & 35.40 & 23.22 & -- & $\cdots$ & $\because$ & $\cdots$ & - & -- \\
\hline 2009 & 66.52 & 60.18 & 49.96 & 33.24 & 21.77 & 60 & 1.1087 & 1.0030 & 0.8327 & 0.5539 & 0.3629 \\
\hline 2034 & 65.92 & 59.64 & 49.51 & 32.93 & 21.57 & $\cdots$ & $\because$ & $\cdots$ & $\cdots$ & $\cdots$ & $\cdots$ \\
\hline 2243 & 61.14 & 55.30 & 45.90 & 30.49 & 19.94 & $-\cdot$ & $\because$ & $\cdots$ & $\cdots$ & $=$ & $\because$ \\
\hline 3000 & 46.54 & 42.06 & 34.87 & 23.08 & 15.00 & $\cdots$ & $\cdots$ & $\cdots$ & -- & $\cdots$ & $\cdots$ \\
\hline 4353 & 41.87 & 37.84 & 31.37 & 20.76 & 13.49 & $\cdots$ & $\cdots$ & $\cdots$ & $\cdots$ & $-\cdot$ & $-\cdot$ \\
\hline $5000^{\circ}$ & 39.80 & 35.97 & 29.82 & 19.73 & 12.82 & $\cdots$ & $\cdots$ & $\because$ & $\because$ & $\cdots$ & $\cdots$ \\
\hline 5900 & 37.09 & 33.53 & 27.79 & 18.39 & 11.95 & $\because$ & $\cdots$ & $\cdots$ & $\because$ & $\cdots$ & $\cdots$ \\
\hline \multicolumn{7}{|c|}{ Average (calculated/measured) } & 1.1087 & 1.0030 & 0.8327 & 0.5539 & 0.3629 \\
\hline
\end{tabular}

"ISOSHLD-II calculated dose rates. Other decay times were linearly interpolated using the logarithm of the dose rate (dependent variable) versus decay time (independent variable).

Five-Region Canister Top ISOSHLD-11 Model Configuration.

\begin{tabular}{|l|c|c||l|l|l|}
\hline Fuel height: & $65.33 \mathrm{~cm}$ & $(25.72 \mathrm{in.})$ & Lid thickness: & $1.270 \mathrm{~cm}$ & $(0.50 \mathrm{in.})$ \\
\hline Zirconium thickness: & $0.4826 \mathrm{~cm}$ & $(0.19 \mathrm{in.})$ & Nater thickness: & Various & (Various) \\
\hline Air thickness: & $0.5588 \mathrm{~cm}$ & $(0.22 \mathrm{in.)}$ & \multicolumn{2}{|c|}{ NOTE: Expl icit model for 2irconium encaps. }
\end{tabular}

\begin{tabular}{|c|c|c|c|c|c|}
\hline Homogenized cenister contents & model in. & $\begin{array}{l}+4 k \text { in. } \\
\text { model }\end{array}$ & $\begin{array}{l}+1 \text { in. } \\
\text { Model. }\end{array}$ & $\begin{array}{l}+2 \text { in. } \\
\text { Model }\end{array}$ & Model in. \\
\hline Uranium $\left(\mathrm{g} / \mathrm{cm}^{3}\right)$ & 18.63 & 18.63 & 18.63 & 18.63 & 18.63 \\
\hline Zirconium $\left(\mathrm{g} / \mathrm{cm}^{3}\right)$ & 0.00 & 0.00 & 0.00 & 0.00 & 0.00 \\
\hline Water $\left(\mathrm{g} / \mathrm{cm}^{3}\right)$ & 0.00 & 0.00 & 0.00 & 0.00 & 0.00 \\
\hline Buildup factor for shield & Canister contents & Canister contents & Canister contents & Canister contents & Cenister contents \\
\hline
\end{tabular}


Representative ISOSHLD-II input files are included in Appendix C, and part of an ISOSHLD-II output is included in Appendix D.

The reconstructed SCATS (Safeguards Control and Accountability Iransaction system) accountabi1 ity database was used for the irradiated fuel isotopic composition and thus fuel exposure records. This accountability database is described in Section 2.4.2.

\subsubsection{Canister Storage Location Geometry}

The 1991 full-basin ISOSHLD-II model was a rectangular cuboid that calculated the dose rate above the canister array (Wittekind 1991). This ISOSHLD-II model was conservative because everything in the storage location was homogenized. The 1991 ful7-basin ISOSHLD-II model was also very conservative because the dose rates were calculated at the surface of the basin water.

This 1994 static storage array ISOSHLD-II model is built up from a single canister half model, which was referenced to experimental measurements. One extension of the five-region canister top model is to use the water shield dose buildup, which is appropriate for deep penetration through water.

Another extension is from the cylinder end geometry into rectangular geometry. The detailed geometry is described in Table 10 and shown in Figure 6.

Table 10. Five-Region Storage Location ISOSHLD-II Models.

\begin{tabular}{|l|c|c|c|c|}
\hline $\begin{array}{c}\text { Homogenized } \\
\text { canister } \\
\text { contents }\end{array}$ & $\begin{array}{c}\text { Model } \\
\# 4 T A\end{array}$ & $\begin{array}{c}\text { Model } \\
\# 5 T A\end{array}$ & $\begin{array}{c}\text { Model } \\
\# 6 T A\end{array}$ & $\begin{array}{c}\text { Model } \\
\# 6 T B\end{array}$ \\
\hline Uranium $\left(\mathrm{g} / \mathrm{cm}^{3}\right)$ & 18.63 & 18.63 & 18.63 & 18.63 \\
\hline $\begin{array}{l}\text { Buildup factor } \\
\text { for shield }\end{array}$ & $\begin{array}{c}\text { Canister } \\
\text { contents }\end{array}$ & Water & Water & Water \\
\hline Geometry & Cylinder & Cyl inder & $\begin{array}{c}\text { Canister } \\
\text { rectangle }\end{array}$ & $\begin{array}{c}\text { Storage location } \\
\text { half-rectangle }\end{array}$ \\
\hline
\end{tabular}

NOTES:

Fuel height: $65.3288 \mathrm{~cm}(25.72$ in.).

Zirconium endcap: $0.4826 \mathrm{~cm}(0.19$ in.).

Air gap above fuel: $0.5588 \mathrm{~cm}(0.22 \mathrm{in.})$.

Stainless steel 1id: $1.27 \mathrm{~cm}$ (0.50 in.).

Water shield thickness: various (various).

The rectangular geometry is then expanded to full fuel storage array. The same fission product gamma ray source is used in all of these storage location geometries. This storage location model is demonstrated to be consistent with the canister top geometry as far as ISOSHLD-II dose rates are concerned. These results are listed in Table 11. 


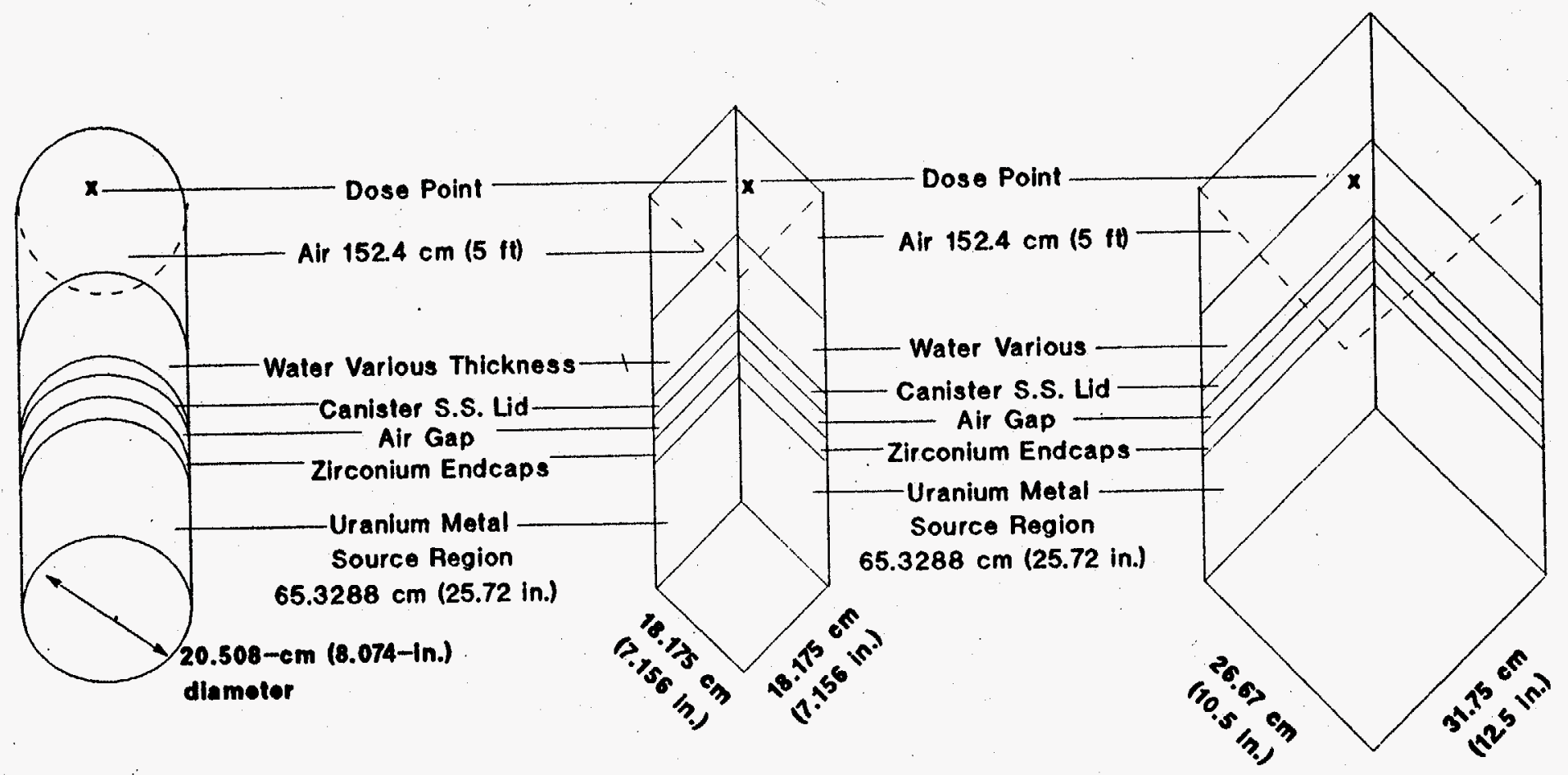

Dose point on axis at cylinder end.

Cylinder size is canister barrel interior dimension.
Dose point on square axis.

Square size is canister barrel equivalent.
Dose point on rectangle axis of symmetry.

Rectangle size is one-half canister storage location. 
Table 11. Five-Region Storage Location ISOSHLD-II Dose Rates.

\begin{tabular}{|c|c|c|c|c|c|}
\hline \multicolumn{2}{|c|}{ Water depth } & \multirow{2}{*}{$\begin{array}{c}\text { Model \#4TA } \\
(\mathrm{mR} / \mathrm{h})\end{array}$} & \multirow{2}{*}{$\begin{array}{l}\text { Model \#5TA } \\
(\mathrm{mR} / \mathrm{h})\end{array}$} & \multirow{2}{*}{$\begin{array}{l}\text { Model \#6TA } \\
(\mathrm{mR} / \mathrm{h})\end{array}$} & \multirow{2}{*}{$\begin{array}{l}\text { Model \#6TB } \\
(\mathrm{mR} / \mathrm{h})\end{array}$} \\
\hline$(\mathrm{cm})$ & $(\mathrm{ft})$ & & & & \\
\hline 7.62 & 0.25 & 990.0 & 3755. & 3984 . & 3959. \\
\hline 15.24 & 0.50 & 562.0 & 2354. & 2499. & 2482. \\
\hline 30.48 & 1 & 186.4 & 886.4 & 941.6 & 935.3 \\
\hline 60.96 & 2 & 24.15 & 121.4 & 129.1 & 128.2 \\
\hline 91.44 & 3 & 3.876 & 17.86 & 18.99 & 18.87 \\
\hline 121.92 & 4 & 0.7171 & 2.970 & 3.157 & 3.140 \\
\hline 152.40 & 5 & $1.431 \mathrm{E}-01$ & $5.541 E-01$ & $5.892 E-01$ & $5.863 E-01$ \\
\hline 182.88 & 6 & 2.966 E-02 & $1.123 \mathrm{E}-01$ & $1.194 \mathrm{E}-01$ & $1.189 E-01$ \\
\hline 213.36 & 7 & $6.286 \mathrm{E}-03$ & $2.394 \mathrm{E}-02$ & $2.547 \mathrm{E}-02$ & $2.537 E-02$ \\
\hline 243.84 & 8 & $1.352 \mathrm{E}-03$ & $5.257 \mathrm{E}-03$ & 5.597 E-03 & $5.575 E-03$ \\
\hline 274.32 & 9 & $2.941 \quad E-04$ & 1.175 E-03 & $1.252 \mathrm{E}-03$ & $1.247 \mathrm{E}-03$ \\
\hline 304.80 & 10 & $6.461 E-05$ & $2.660 E-04$ & $2.834 E-04$ & 2.824 E-04 \\
\hline
\end{tabular}

\subsubsection{Reconstructed SCATS Database}

The reconstructed SCATS database (Schlosser 1990, 1992a, and 1992b) contains an inventory of the KE and KW irradiated fuel in mass and isotopic composition. The Advanced Planning organization of the United Nuclear Corporation was located in the 480 classified computing complex and had access to the then secret (now declassified) isotopic tables for calculating N Reactor fuel isotopic composition for delivery to the Plutonium-Uranium Extraction (PUREX) Plant. Two isotopic tables were used to calculate fuel composition: isotopic production tables (Wittekind 1988a) and isotopic segregation tables (Wittekind 1986).

The isotopic production tables used $N$ Reactor measured heat generation to infer exposure and, thus, uranium and plutonium isotopics. These isotopic compositions were referenced to PUREX D-5 mass spectrometer analyses performed by Pacific Northwest Laboratory (PNL) on special dissolver batches with known N Reactor discharged fuel.

The isotopic segregation tables used neutron count rates in the fuel segregation detector (Wittekind 1984) in the 105-KE Basin. The fuel segregation program, which counted irradiated fuel elements in an underwater neutron detector, inferred the $240 \mathrm{Pu}$ wt\% for irradiated uranium. At first this was done element by element. Later, when the inners and outers were not separated, this was done by whole assemblies. The neutron counts were referenced to neutron counts in calibration elements of known ${ }^{240} \mathrm{Pu}$ wt\% assay. 
These standard elements were paired with other $\boldsymbol{N}$ Reactor fuel elements, which were destructively analyzed. The destructive analysis yielded isotopic compositions from about nine different mass spectrometer analyses performed by PNL on sections. These single-element analyses were used to define the burnup curve for the isotopic segregation tables.

N Reactor fuel discharges were accounted for separately from previous fuel discharges and called "keys." The keys were originally discharge keys, but with intrabasin and interbasin "heel" transfers, these keys acquired a different identity, that of a basin key based on storage locations. Heel transfers were a convenience to transfer some fuel elements from one discharge key into another discharge key because of basin transfers, canister filling, or some other reason. The basin key could maintain about $90 \%$ to $95 \%$ of the discharge key identity. The reconstructed SCATS fuel accountability tables were originally discharge key-based and depended on $N$ Reactor production computing results. The goal of the reconstructed SCATS database was accurate isotopic quantity records. Later, Jim Schlosser made adjustments to match the accountability records for basin keys, which involved some heel transfers from one discharge key to another discharge key.

The reconstructed SCATS database formed the starting point for the maximum radiation dose rate calculations. This database resides in a spreadsheet with quantities and compositions for each separate basin key. The key date was used to calculate the decay time; this is not accurate, but it is conservative. For example, the key 14355 (or 4355B, 4355C, 4355D, and 4356D) is composed of fuel in canisters believed to contain MKIA spike column MKIV ends taken from a number of older keys, which were then designated as this new basin key 14355. Also, key 09621 contains SPR fuel elements that were discovered at different times and under different conditions and are simply combined together as this basin key. Appendix A presents a partial listing of the reconstructed SCATS database.

\subsubsection{Single Canister Irradiation Calculation}

The fuel storage array ISOSHLD-II model needs to accommodate the range of fuel exposures in the 105-KE and 105-KW Basins, not just the fuel exposures used for the experimental measurements. Two possible situations would give the highest radiation dose rate: (1) the shortest decay time and (2) the highest fuel exposure. Table 12 compares these two situations for the storage location geometry. The highest fuel exposure calculates the highest gamma dose rate.

The $6 w t \%{ }^{240} \mathrm{Pu}$ irradiation input parameters are used in all ISOSHLD-II models before this point in this document. The 16 wt\% $240 \mathrm{Pu}$ irradiation input parameters are used in all ISOSHLD-II models after this point in this document.

The dominant isotope contributing to the gamma radiation is ${ }^{137} \mathrm{Cs}$. The significance of uranium irradiation then is the quantity of ${ }^{137} \mathrm{Cs}$. 
Table 12. Irradiation Exposure, Decay ISOSHLD-II Comparison.

\begin{tabular}{|c|c|c|c|}
\hline \multicolumn{2}{|c|}{ Water depth } & \multirow{2}{*}{$\begin{array}{c}\text { Model } \\
\# 6 \mathrm{~TB}(6) \\
(\mathrm{mR} / \mathrm{h})\end{array}$} & \multirow{2}{*}{$\begin{array}{c}\text { Mode1 } \\
\# 6 T B(16) \\
(\mathrm{mR} / \mathrm{h})\end{array}$} \\
\hline (cm) & $(f t)$ & & \\
\hline 7.62 & 0.25 & 673.5 & 2219. \\
\hline 15.24 & 0.50 & 409.1 & 1349. \\
\hline 30.48 & 1 & 141.4 & 466.9 \\
\hline 60.96 & 2 & 14.88 & 49.38 \\
\hline 91.44 & 3 & 1.466 & 4.898 \\
\hline 121.92 & 4 & 0.1421 & 0.4789 \\
\hline 152.40 & 5 & $1.391 \mathrm{E}-02$ & 4.740 E-02 \\
\hline 182.88 & 6 & 1.414 E-03 & $4.862 E-03$ \\
\hline 213.36 & 7 & $1.546 E-04$ & $5.318 \quad E-04$ \\
\hline 243.84 & 8 & $1.909 \mathrm{E}-05$ & $6.413 \mathrm{E}-05$ \\
\hline 274.32 & 9 & $2.758 E-06$ & $8.759 E-06$ \\
\hline 304.80 & 10 & 4.671 E-07 & $1.363 \mathrm{E}-06$ \\
\hline
\end{tabular}

The reconstructed SCATS accountability database was assembled from isotopic production tables, which converted $N$ Reactor exposure measured in MWd/MTU into wt\% ${ }^{240} \mathrm{Pu}$, and isotopic segregation tables, which converted counts in a neutron detector into wt\% ${ }^{240} \mathrm{Pu}$. The $w t \%{ }^{240} \mathrm{Pu}$ is a convenient measurement of uranium irradiation.

The RIBD code is built into ISOSHLD-II so dose rates can be calculated from irradiated uranium. Another, more standard, isotopic calculation is ORIGEN2 (Croff 1980; Wittekind 1994c; Schmittroth 1993), which was used to calculate the decay heat of irradiated N Reactor fuel in 105-KE and 105-KW Basins. ORIGEN2 was used to calculate isotopic composition of irradiated N Reactor fuel (Hedengren 1985, 1986; Hedengren and Goldberg 1987), and to calculate decay heat for 105-KE and 105-KW Basins (Wittekind 1994a).

Consider model \#6TB(6), nominally a 6 wt\% ${ }^{240} \mathrm{Pu}$ irradiation calculation by RIBD in ISOSHLD-II. The quantity of MKIV considered in one canister half, or seven elements, which are at the most $23.41 \mathrm{~kg}(51.6 \mathrm{lb})$ weight per $66.294 \mathrm{~cm}(26.1$ in.) long per element. This is a calculated mass of $163.8 \mathrm{~kg}$ $(361.2 \mathrm{lb})$. Table 13 lists the RIBD calculated ${ }^{137} \mathrm{Cs}$ inventory. 
Table 13. RIBD Calculated ${ }^{137}$ Cs Inventory.

( ${ }^{137}$ Cs Curies for Canister Half [163.8 kg] Scaled to Curies/MTU.)

\begin{tabular}{|l|c|c|c|c|c|}
\hline \multicolumn{1}{|c|}{6 wt\% ${ }^{260} \mathrm{Pu}$} & Discharge & $\begin{array}{c}3,669 . \text { days } \\
(10.05 \text { years })\end{array}$ & $\begin{array}{c}4,664 . \text { days } \\
(12.77 \text { years })\end{array}$ & $\begin{array}{c}6,667 . \text { days } \\
(18.25 \text { years })\end{array}$ & $\begin{array}{c}8,669 . \text { days } \\
(23.73 \text { years })\end{array}$ \\
\hline $\mathrm{Ci} /$ canister half & 688.8 & 546.1 & 512.7 & 451.7 & 398.0 \\
\hline $\mathrm{Ci} / \mathrm{MTU}$ & $4,204$. & $3,333$. & $3,129$. & $2,757$. & $2,429$. \\
\hline
\end{tabular}

\begin{tabular}{|l|c|c|c|c|c|}
\hline 16 wt\% ${ }^{240} \mathrm{Pu}$ & Discharge & $\begin{array}{c}5,266 . \text { days } \\
(14.42 \text { years })\end{array}$ & $\begin{array}{c}6,262 . \text { days } \\
(17.14 \text { years })\end{array}$ & $\begin{array}{c}8,264 . \text { days } \\
(22.63 \text { years })\end{array}$ & $\begin{array}{c}10,266 . \text { days } \\
(28.11 \text { years })\end{array}$ \\
\hline Ci/canister half & $2,494$. & $1,787$. & $1,687$. & $1,478$. & $1,302$. \\
\hline Ci/MTU & $15,222$. & $10,907$. & $10,297$. & $9,021$. & $7,947$. \\
\hline
\end{tabular}

Canister half $=163.8 \mathrm{~kg}$ uranium inventory.

As a check, calculation of discharge ${ }^{137} \mathrm{Cs}$ from $N(t=0)=N(t) * \exp \left(+\ln (2) * t / t_{y_{2}}\right)$, using the different decay time does reproduce discharge ${ }^{137}$ Cs activity from different decay times. The half-life of ${ }^{137} \mathrm{Cs}$ is 30.17 years, but RIBD used the value 10,950 days (29.98 years), so a negligible difference $(0.33 \%$ at 23.73 years decay) occurs.

From the ISOSHLD-II input, the RIBD-ISOSHLD-II specific power is:

$$
1.84625 \mathrm{MW} / 0.1638 \mathrm{MT}=11.27 \mathrm{MW} / \mathrm{MT} \text {, }
$$

the irradiation exposure for the 16 wt\% ${ }^{240} \mathrm{Pu}$ case is:

$$
\text { (1.84625 MW / } 0.1638 \mathrm{MT}) \times 406 \mathrm{~d}=4576 \mathrm{MWd} / \mathrm{MT} \text {, }
$$

and the RIBD-ISOSHLD-II discharge ${ }^{137} \mathrm{Cs}$ is:

$$
\left(2.494 \mathrm{E}+3 \mathrm{Ci}{ }^{137} \mathrm{Cs} / 0.1638 \mathrm{MT}\right)=15,222 . \mathrm{Ci}{ }^{137} \mathrm{Cs} / \mathrm{MT} \text {. }
$$

ORIGEN2 calculation for discharge ${ }^{137} \mathrm{Cs}$ for irradiation exposure of the 16.333 wt\% ${ }^{240} \mathrm{Pu}$ maximum exposure key will be calculated from ORIGEN2 results tabulated in Table 14. The specific power for MKIV fuel is $11.00 \mathrm{MW} / \mathrm{MT}$. Key 11540 at 16.333 wt\% ${ }^{240} \mathrm{Pu}$ was calculated for January 31 , 1992, which is Hanford Atomic Products Operations (HAPO) day 18024. The HAPO day calendar began on September 27, 1942. This decay time is 17.75 years. ([18024 days - 11540 days $]+365.25$ days/year $=17.75$ years.) ORIGEN2 calculation for MUd/MT and ${ }^{137}$ Cs activity at discharge will use two-dimensional interpolation. The two-dimensional interpolation is for decay time and exposure. Table 14 shows slow change with decay time and more dramatic change with wt\% ${ }^{240} \mathrm{Pu}$ exposure (irradiation or burnup). 
Table 14. ORIGEN2 Results for Determining ${ }^{137}$ Cs Activity.

\begin{tabular}{|c|c|c|c|c|c|c|c|c|c|c|c|c|}
\hline \multirow{3}{*}{$\begin{array}{l}\text { Exposure } \\
\text { case }\end{array}$} & \multicolumn{12}{|c|}{ Decay time (years) } \\
\hline & 0 & 5 & 10 & 15 & 20 & \begin{tabular}{l|l}
25 & \\
\end{tabular} & 30 & 35 & 40 & 45. & 50 & 55 \\
\hline & \multicolumn{12}{|c|}{${ }^{137} \mathrm{Cs}$ (curies/MTU) } \\
\hline 3 wtx & 1758. & 1566. & 1395. & 1243. & 1108. & 986.7 & 879.0 & 783.1 & 697.7 & 621.6 & 553.8 & 493.3 \\
\hline 6 wtX & 3516. & 3133. & 2791. & 2486. & 2215. & 1973. & 1758. & 1566. & 1395. & 1243. & 1108. & 986.7 \\
\hline 9 wtx & 5863. & 5224. & 4654. & 4146. & 3694. & 3291. & 2932. & 2612. & 2327. & 2073. & 1847. & 1645. \\
\hline $12 w+x$ & 8838. & 7873. & 7014. & 6249. & 5567. & 4960. & 4419. & 3937. & 3507. & 3124. & 2784. & 2480. \\
\hline \multirow[t]{2}{*}{16 wtX } & 12980. & 11570. & 10310. & 9181. & 8179. & 7287. & 6492. & 5783. & 5152. & 4590. & 4089. & 3643. \\
\hline & \multicolumn{12}{|c|}{$240 \mathrm{Pu}$ (grams/MTU) } \\
\hline 3 wty & 18.44. & 18.43 & 18.42 & 18.41 & 18.40 & 18.39 & 18.38 & 18.38 & 18.37 & 18.36 & 18.35 & 18.34 \\
\hline $6 \mathrm{wtx}$ & 62.53 & 62.50 & 62.46 & 62.43 & 62.40 & 62.36 & 62.33 & 62.30 & 62.26 & 62.23 & 62.20 & 62.17 \\
\hline 9 wex & 139.9 & 139.8 & 139.7 & 139.7 & 139.6 & 139.5 & 139.4 & 139.4 & 139.3 & 139.2 & 139.1 & 139.1 \\
\hline 12 wtx & 253.5 & 253.4 & 253.3 & 253.2 & 253.1 & 252.9 & 252.8 & 252.7 & 252.5 & 252.4 & 252.3 & 252.1 \\
\hline \multirow[t]{2}{*}{16 wtX } & 425.9 & 425.8 & 425.7. & 425.5 & 425.3 & 425.1 & 424.9 & 424.7 & 424.5 & 424.3 & 424.1 & 423.9 \\
\hline & \multicolumn{12}{|c|}{ Pu (grams/MTU) } \\
\hline $3 w+x$ & 487.0 & 524.1 & 523.8 & 523.6 & 523.4 & 523.2 & 523.0 & 522.9 & 522.7 & 522.6 & 522.5 & 522.4 \\
\hline $6 \mathrm{wtx}$ & 931.9 & 966.5 & 965.0 & 963.7 & 962.7 & 961.9 & 961.2 & 960.6 & 960.1 & 959.6 & 959.3 & 958.9 \\
\hline $9 \mathrm{wtx}$ & 1475. & .1506. & 1501. & 1496. & 1493. & 1490. & 1488. & 1487. & 1485. & 1484. & 1483. & 1482. \\
\hline 12 wtx & 2063. & 2085. & 2073. & 2063. & 2055. & 2049. & 2044. & 2040. & 2037. & 2034. & 2032. & 2030. \\
\hline \multirow[t]{2}{*}{16 wtY } & 2774. & 2781. & 2756. & 2737. & 2722. & \begin{tabular}{|l|l|}
2709. \\
\end{tabular} & 2700 & 2692. & 2685. & 2680. & 2676. & 2673. \\
\hline & \multicolumn{12}{|c|}{ Wt $x^{240}$ Pu (calculated from 240 Pu/Pu $\left.\times 100.0\right)$} \\
\hline $3 w+x$ & 3.79 & 3.52 & 3.52 & 3.52 & 3.52 & 3.51 & 3.51 & 3.52 & 3.51 & 3.51 & 3.51 & 3.51 \\
\hline $6 w+x$ & 6.71 & 6.47 & 6.47 & 6.48 & 6.48 & 6.48 & 6.48 & 6.49 & 6.48 & 6.48 & 6.48 & 6.48 \\
\hline 9 wtx & 9.48 & 9.28 & 9.31 & 9.34 & 9.35 & 9.36 & 9.37 & 9.37 & 9.38 & 9.38 & 9.38 & 9.39 \\
\hline $12 w+x$ & 12.29 & 12.15 & 12.22 & 12.27 & 12.32 & 12.34 & 12.37 & 12.39 & 12.40 & 12.41 & 12.42 & 12.42 \\
\hline \multirow[t]{2}{*}{$16 w+x$} & 15.35 & 15.31 & 15.45 & 15.55 & 15.62 & 15.69 & 15.74 & 15.78 & 15.81 & 15.83 & 15.85 & 15.86 \\
\hline & \multicolumn{12}{|c|}{ ORIGEN2 calculated irradiation (MUd/MT) } \\
\hline $\begin{array}{r}3 w+x \\
6 \text { wtx } \\
9 w+x \\
12 w+x \\
16 \text { wtx }\end{array}$ & $\begin{array}{l}(11.88 \mathrm{~m} / \mathrm{m} \\
(11.88 \mathrm{~mW} / \mathrm{m} \\
(11.88 \mathrm{~m} / \mathrm{M} \\
(11.88 \mathrm{~mW} / \mathrm{m} \\
(11.88 \mathrm{~m} / \mathrm{m} \\
(11.88\end{array}$ & $\begin{array}{l}T \text { outer } x \\
\text { T outer } x \\
\text { outer } x \\
\text { outer } x \\
\text { outer } x \\
\end{array}$ & $\begin{array}{l}683 \text { outer } \\
683 \text { outer } \\
683 \text { outer } \\
683 \text { outer } \\
683 \text { outer } \\
\end{array}$ & $\begin{array}{l}\text { fraction + } \\
\text { fraction + } \\
\text { fraction + } \\
\text { fraction + } \\
\text { fraction + } \\
\end{array}$ & $\begin{array}{l}13 \mathrm{MH} / \mathrm{MT} \\
13 \mathrm{MW/MT} \\
13 \mathrm{MW/MT} \\
13 \mathrm{MW/MT} \\
13 \mathrm{MU/MT}\end{array}$ & 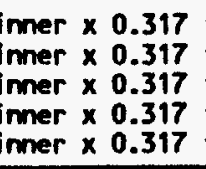 & $\begin{array}{l}\text { inner frac } \\
\text { inner frac } \\
\text { inner frac } \\
\text { inner frac } \\
\text { inner frac }\end{array}$ & $\begin{array}{lll}(i o n) & \times & 50 \\
\text { tion) } & \times & 100 \\
\text { tion) } & \times 166.6 \\
\text { tion) } & \times 250 \\
\text { ion) } & \times 362.6\end{array}$ & $\begin{aligned} d & =550 \\
d & =1101 \\
d & =1834 \\
d & =2752 \\
d & =3992\end{aligned}$ & 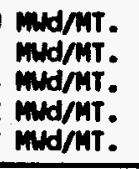 & & \\
\hline
\end{tabular}


Linear interpolation will be performed on decay time, and quadratic interpolation will be performed on the wt\% ${ }^{240} \mathrm{Pu}$ exposure. First, the wt\% ${ }^{240} \mathrm{Pu}$ will be calculated at 17.75 years decay. The ORIGEN2 ${ }^{240} \mathrm{Pu}$ (grams) and $\mathrm{Pu}$ (grams) are both linearly interpolated using the 15-year and 20-year decay values for the 9 wt\%, 12 wt\%, and 16 wt\% cases to locate the 17.75-year decay values, division is done to determine the ORIGEN2 wt\% $240 \mathrm{Pu}$ at 17.75 years decay. Three-point lagrangian interpolation on the ${ }^{240} \mathrm{Pu}$ wt\% exposure uses the following formula.

$(16.333-12.295)(16.333-15.676) f(9)+(16.333-9.344)(16.333-15.676) f(12)+(16.333-9.344)(16.333-12.295) f(16)=$

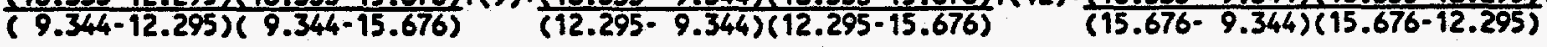

\section{$0.1420785548 f(9 w t \%)+-0.4604778187 f(12 w t \%)+1.318399264 f(16 w t \%)$}

Use exposure, MWd/MT, and ${ }^{137} \mathrm{Cs}$, discharge curies, at the 9,12 , and 16 wt\% points to find the ORIGEN2 calculated exposure and discharge ${ }^{139} \mathrm{Cs}$ :

$$
16.333 w t \%{ }^{240} \mathrm{Pu} \Rightarrow 4256 \mathrm{MWd} / \mathrm{MT} \& 13,876 \mathrm{Ci}{ }^{137} \mathrm{Cs} \text {. }
$$
content.

Now, RIBD-ISOSHLD-II can be compared to ORIGEN2 for exposure and ${ }^{137} \mathrm{Cs}$

RIBD-ISOSHLD irradiation compared to ORIGEN2 irradiation is:

4576. MWd/MT / 4256.MWd/MT $=1.075$ or $7.5 \%$ higher in exposure and

$$
15,222 \mathrm{Ci}{ }^{137} \mathrm{Cs} / 13,876 \mathrm{Ci}{ }^{137} \mathrm{Cs}=1.097 \text { or } 10 \% \text { higher in }{ }^{137} \mathrm{Cs} \text {. }
$$

This demonstrates that the RIBD-ISOSHLD irradiation is consistent, but about $7.5 \%$ conservative (high), with the maximum key exposure in either 105-KE or 105-KW Basin, and consistent, but conservative (high) about $2.5 \%$ $(10 \%-7.5 \%=2.5 \%)$, with ORIGEN2-calculated ${ }^{137}$ Cs content at discharge for the same MWd/MT (or wt\% ${ }^{240} \mathrm{Pu}$ ). This RIBD-ISOSHLD calculated ${ }^{137} \mathrm{Cs}$ content, which is approximately $10 \%$ higher than ORIGEN2 calculated ${ }^{137}$ Cs content, is a conservative (safe) factor in this dose rate and shielding calculation.

The dose rate of interest is at the basin grating, $152.40 \mathrm{~cm}(5 \mathrm{ft})$ to $167.64 \mathrm{~cm}\left(5 \frac{1}{2} \mathrm{ft}\right)$ above the water surface level, where people will be working. This increased the number of regions to six (last region is air). The ISOSHLD-II calculated dose rate is expanded from a half canister storage location to 1,800 canister storage locations in incremental steps. The largest dose rate contribution comes from the canisters directly below the water surface, not due to the canisters further removed by angle and distance.

The 1991 ISOSHLD-II model was very conservative and resulted in calculated dose rates which were certainly too high. The 1991 ISOSHLD-II model homogenized the canister contents, resulting in reduced shielding material above the fuel source and reduced distance to the calculated dose. points. The present improved model is consistent with experimental measurements and still provides a conservative (high) calculation of radiation dose rate. 
A fine point in comparing RIBD-ISOSHLD with ORIGEN2 is that RIBD calculates only the fission product gamma rays, while ORIGEN2 calculates activation product, actinide and daughter, and fission product gamma rays.

Table 15 lists the ORIGEN2 gamma ray production for all three categories and their ratio to the total gamma production. The columns on the left are gamma photons/second. The total column sums the contributions from all three ORIGEN2 isotope categories. The columns on the right are the fraction of total gammas in each energy range due to the respective ORIGEN2 isotope category.

It is obvious that $98.96 \%$ of the total gamma photons/second are due to fission products. The higher energy gammas, which are due to actinides and daughters, are due to low-frequency spontaneous fissions that do not add significantly to the total gamma dose rate. A significant feature of the activation products is the ${ }^{80} \mathrm{Co}$ peak which occurs at $1.250 \mathrm{MeV}$. The activation products account for $11.96 \%$ of the total photons/second in this energy range. The ${ }^{60} \mathrm{Co}$ peak energy is $0.80 \%$ of the peak gamma photons/second. $(100 \% * 2.088 \mathrm{E}+12 / 2.624 \mathrm{E}+14=0.80 \%$.)

Table 15 and these calculations are an additional supporting demonstration that the RIBD-ISOSHLD fission product gamma source calculation is a reasonable approximation of the total gamma ray source from irradiated fuel including activation products and the actinides and daughters.

\subsubsection{Static Storage Array Geometry}

The ISOSHLD-II single canister storage location geometry was expanded in stages to 1,800 canister storage locations. The same uranium irradiation was used, and the amount of power expended in the larger quantity of uranium was increased proportionally. The rectangular canister storage location model was increased in spatial size in stages to the entire 1,800 canister storage locations. The greatest proportional increase in calculated dose rate came at the start of the expansion, when more canisters were directly under the dose point. Figure 7 shows the expansion from a single storage location to a fuel basin geometry. The results of building up to this static fuel storage array are tabulated in Table 16.

\subsection{ACTIVE STORAGE ARRAY ISOSHLD-II CALCULATION}

There are three considerations in applying the static storage array ISOSHLD-II model and applying dose rate calculations to practical irradiated fuel storage basin operations:

1. A canister is lifted out of its storage location and moved over the static array to another location

2. Several canisters are lifted above the storage array simultaneousiy

3. Higher water temperature reduces water density that affects the radiation shielding and increases the calculated dose rate. 
Table 15. ORIGEN2 Calculated Gamma Ray Production.

\begin{tabular}{|c|c|c|c|c|c|c|c|}
\hline \multirow{2}{*}{$\begin{array}{c}\text { Averoge } \\
\text { garmm ray energy } \\
\text { (MeV) }\end{array}$} & \multicolumn{4}{|c|}{ Gamma photons/second } & \multicolumn{3}{|c|}{ fractions relative to total gamme production } \\
\hline & $\begin{array}{l}\text { Activation } \\
\text { products }\end{array}$ & $\begin{array}{l}\text { Actinides and } \\
\text { daughters }\end{array}$ & $\begin{array}{l}\text { Fission } \\
\text { products }\end{array}$ & Total & $\begin{array}{l}\text { Activation } \\
\text { products } \\
\text { (fraction) }\end{array}$ & $\begin{array}{l}\text { Actinides and } \\
\text { doughters } \\
\text { (fraction) }\end{array}$ & $\begin{array}{l}\text { Fission products } \\
\text { (fraction) }\end{array}$ \\
\hline $1.500 E-02$ & $1.016 E+10$ & $1.546 E+12$ & $2.875 E+13$ & $3.031 E+13$ & 0.0003 & 0.0510 & 0.9487 \\
\hline $2.500 \mathrm{E}-02$ & $1.752 E+11$ & $8.716 E+10$ & $8.814 E+12$ & $9.076 E+12$ & 0.0193 & 0.0096 & 0.9711 \\
\hline 3.750 E-02 & $4.473 E+10$ & $8.161 E+09$ & $2.171 E+13$ & $2.176 \mathrm{E}+13$ & 0.0021 & 0.0004 & 0.9976 \\
\hline 5.750 E-02 & $1.871 E+08$ & $1.278 E+12$ & $5.769 E+12$ & $7.047 \mathrm{E}+12$ & 0.0000 & 0.1813 & 0.8186 \\
\hline 8.500 E-02 & $8.119 E+07$ & $3.211 E+09$ & $3.817 E+12$ & $3.820 E+12$ & 0.0000 & 0.0008 & 0.9991 \\
\hline $1.250 E-01$ & $1.026 E+09$ & $2.375 E+09$ & $3.868 E+12$ & $3.871 E+12$ & 0.0003 & 0.0006 & 0.9991 \\
\hline 2.250 E-01 & $1.574 E+10$ & $1.021 E+09$ & $3.635 E+12$ & $3.652 \mathrm{E}+12$ & 0.0043 & 0.0003 & 0.9954 \\
\hline $3.750 E-01$ & $9.470 E+10$ & $6.780 E+08$ & $3.146 E+12$ & $3.241 \mathrm{E}+12$ & 0.0292 & 0.0002 & 0.9706 \\
\hline 5.750 E-01 & $1.217 \mathrm{E}+11$ & $8.343 E+07$ & $2.624 E+14$ & $2.625 E+14$ & 0.0005 & 0.0000 & 0.9995 \\
\hline $8.500 E-01$ & $3.680 E+07$ & $9.395 E+07$ & $5.785 E+12$ & $5.785 \mathrm{E}+12$ & 0.0000 & 0.0000 & 1.0000 \\
\hline $1.250 \mathrm{E}+00$ & $2.837 E+11$ & $7.395 E+07$ & $2.088 E+12$ & $2.372 E+12$ & 0.1196 & 0.0000 & 0.8804 \\
\hline $1.750 E+00$ & $2.900 E+01$ & $1.197 E+07$ & $6.878 E+10$ & $6.879 E+10$ & 0.0000 & 0.0002 & 0.9998 \\
\hline $2.250 E+00$ & $1.504 E+06$ & $1.930 E+05$ & $9.688 E+09$ & $9.690 E+09$ & 0.0002 & 0.0000 & 0.9998 \\
\hline $2.750 E+00$ & $4.653 E+03$ & $9.479 E+05$ & $3.085 E+08$ & $3.095 E+08$ & 0.0000 & 0.0031 & 0.9969 \\
\hline $3.500 E+00$ & $1.094 E-13$ & $9.981 E+04$ & $4.515 E+07$ & $4.525 E+07$ & 0.0000 & 0.0022 & 0.9978 \\
\hline $5.000 E+00$ & 7.034 E-15 & $4.251 E+04$ & $5.796 E-06$ & $4.251 E+04$ & 0.0000 & 1.0000 & 0.0000 \\
\hline $7.000 E+00$ & 4.558 E-16 & $4.872 E+03$ & 3.761 E-07 & $4.872 E+03$ & 0.0000 & 1.0000 & 0.0000 \\
\hline $1.100 E+01$ & 2.885 E-17 & $5.581 E+02$ & 2.378 E-08 & $5.581 E+02$ & 0.0000 & 1.0000 & 0.0000 \\
\hline Total & $7.473 E+11$ & $2.927 E+12$ & $3.499 E+14$ & $3.535 E+14$ & 0.0021 & 0.0083 & 0.9896 \\
\hline
\end{tabular}

MOTE: Situation: mikiv fuel irradiated to 12 wtz ${ }^{240} \mathrm{Pu}, 10$ years decay. 


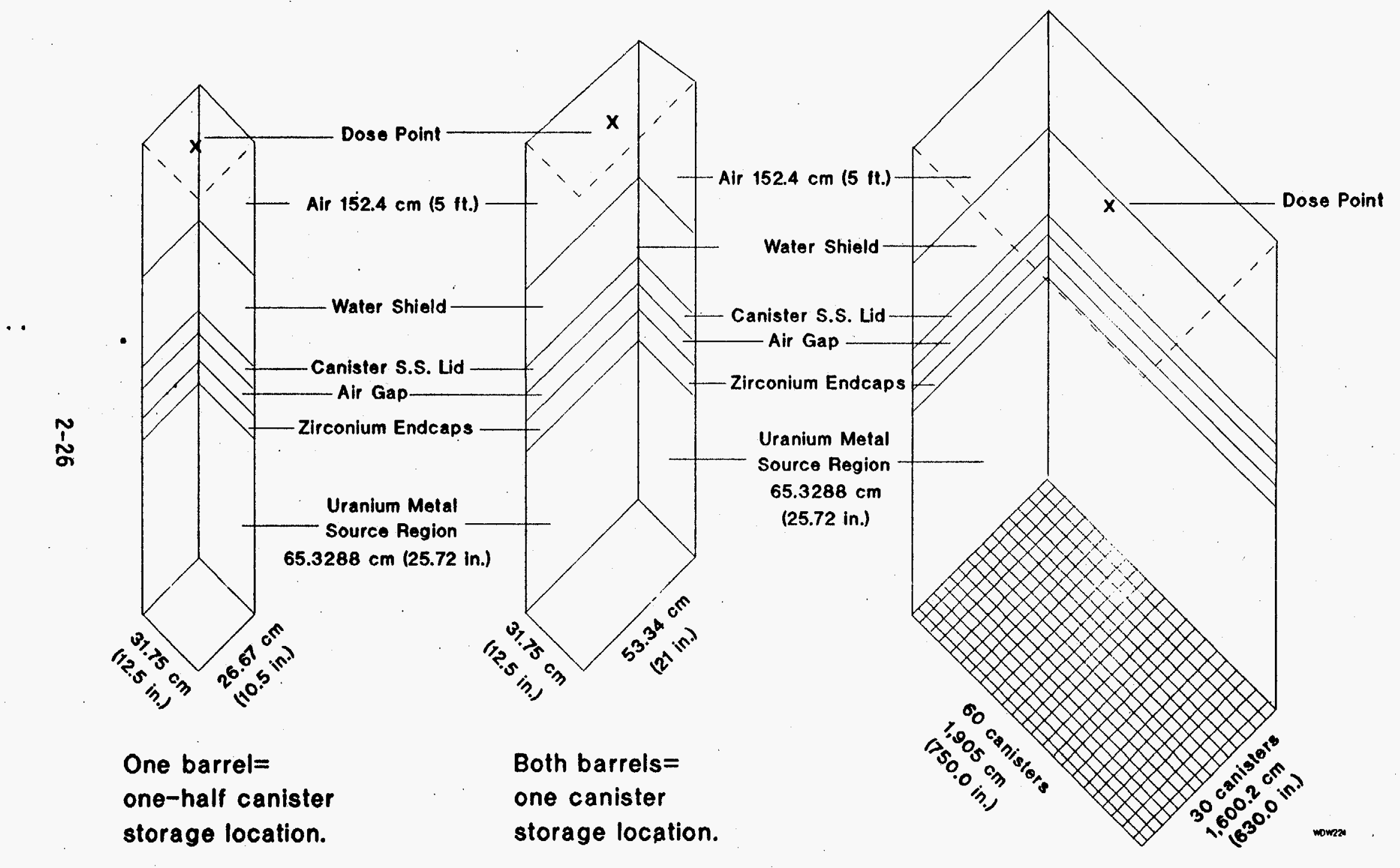

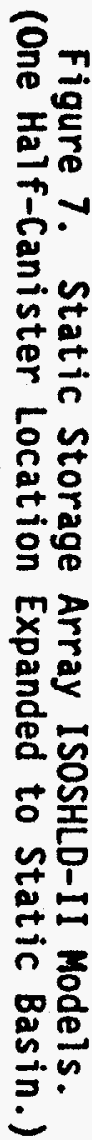
storage location. one canister storage location. 
Table 16. Static Storage Array ISOSHLD-II Dose Rates. (ISOSHLD-II Model has $152.40 \mathrm{~cm}$ [5 ft] Air Above Water Surface.)

\begin{tabular}{|c|c|c|c|c|c|c|c|c|}
\hline \multicolumn{2}{|c|}{ Water depth } & \multirow{2}{*}{$\begin{array}{l}\text { Model } B K^{1} \\
(n R / h)\end{array}$} & \multirow{2}{*}{$\begin{array}{l}\text { Model } B 1^{2} \\
(\mathrm{mR} / \mathrm{h})\end{array}$} & \multirow{2}{*}{$\begin{array}{c}\text { Model } 84^{3} \\
(\mathrm{mR} / \mathrm{h})\end{array}$} & \multirow{2}{*}{$\begin{array}{c}\text { Model B18 } \\
(\mathrm{mR} / \mathrm{h})\end{array}$} & \multirow{2}{*}{$\begin{array}{c}\text { Model } 1550^{5} \\
(\mathrm{mR} / \mathrm{h})\end{array}$} & \multirow{2}{*}{$\begin{array}{c}\text { Model } 8200^{6} \\
(\min / \mathrm{h})\end{array}$} & \multirow{2}{*}{$\begin{array}{c}\text { Model B18007 } \\
(\mathrm{ma} / \mathrm{h})\end{array}$} \\
\hline $\mathrm{cm}$ & $\mathrm{ft}$ & & & & & & & \\
\hline 7.62 & 0.25 & 2219. & 4380. & 16370. & 58140. & 107100. & 159400 & 172600 \\
\hline 15.24 & 0.50 & 1349. & 2661. & 9925. & 34910. & 62960. & 89160. & 93600. \\
\hline 30.48 & 1 & 466.9 & 920.6 & 3422 & 11860. & 20710. & 27440. & 28070. \\
\hline 60.96 & 2 & 49.38 & 97.32 & 360.6 & 1232. & 2084 & 2597. & 2621. \\
\hline 91.44 & 3 & 4.898 & 9.656 & 35.80 & 122.2 & 205.1 & 250.6 & 252.1 \\
\hline 121.92 & 4 & 0.4789 & 0.9446 & 3.510 & 12.06 & 20.34 & 24.82 & 24.95 \\
\hline 152.92 & 5 & 4.740 E-02 & 9.354 E-02 & 3.488 E-01 & $1.212 E+00$ & $2.071 E+00$ & $2.551 E+00$ & $2.566 E+00$ \\
\hline 182.88 & 6 & 4.862 E-03 & 9.603 E-03 & 3.596 E-02 & 1.267 E-01 & 2.207 E-01 & 2.774 E-01 & 2.794 E-01 \\
\hline 213.36 & 7 & 5.318 E-04 & $1.051 E-03$ & 3.957 E-03 & 1.417 E-02 & 2.534 E-02 & 3.279 E-02 & 3.312 E-02 \\
\hline 243.84 & 8 & $6.413 E-05$ & $1.269 E-04$ & $4.802 E-04$ & 1.753 E-03 & 3.232 E-03 & 4.345 E.03 & 4.407 E-03 \\
\hline 274.32 & 9 & 8.759 E-06 & $1.735 . E-05$ & $6.602 E-05$ & $2.459 E=04$ & 4.679 E-04 & 6.57.1 E-04 & $6.700 E-04$ \\
\hline 304.80 & 10 & $1.363 \mathrm{E}-06$ & 2.704 E-06 & 1.034 E-05 & 3.919 E-05 & 7.683 E-05 & 1.125 E- 04 & $1.154 E-04$ \\
\hline 335.28 & 11 & 2.374 E-07 & 4.711 E-07 & 1.809 E-06 & 6.955 E-06 & $1.397 E-05$ & $2.124 E-05$ & $2.191 E-05$ \\
\hline 365.76 & 12 & $4.483 E-08$ & 8.902 E-08 & $3.428 E-07$ & 1.333 E-06 & $2.731 E-06$ & 4.283 E-06 & $4.444 E-06$ \\
\hline 396.24 & 13 & 8.934 E-09 & 1.775 E-08 & 6.852 E-08 & 2.688 E-07 & 5.594 E-07 & 9.012 E-07 & $9.401 E-07$ \\
\hline 426.72 & 14 & 1.843 E-09 & 3.663 E-09 & $1.417 E-08$ & 5.600 E-08 & $1.180 \mathrm{E}-07$ & $1.948 E-07$ & $2.043 E-07$ \\
\hline 457.20 & 15 & 3.892 E-10 & 7.737 E-10 & 2.998 E-09 & 1.192 E-08 & $2.541 E-08$ & 4.285 E-08 & 4.520 E-08 \\
\hline 487.68 & 16 & 8.350 E-11 & $1.661 E-10$ & $6.443 E-10$ & 2.575 E- 09 & 5.547 E-09 & 9.547 E-09 & $1.013 E-08$ \\
\hline
\end{tabular}

Model Bh is one-half canister (one cyl inder, barrel only), $31.75 \mathrm{~cm}$ (12.5 in.) $\times 26.67$ (10.5 in.).

Model B1 is one canister (both cylinders), 31.75 (12.5 in.) $\times 53.34 \mathrm{~cm}(21.0 \mathrm{in.}$.).

3 Nodel 84 is 4 canisters, $63.50 \mathrm{~cm}(25.0 \mathrm{in.}) \times 106.68 \mathrm{~cm}(42.0 \mathrm{in.})$.

4 Model 818 is 18 canisters, $190.50 \mathrm{~cm}(75.0 \mathrm{in.}) \times 160.02 \mathrm{~cm}(63.0 \mathrm{in.})$;

5 Model 850 is 50 canisters, $317.50 \mathrm{~cm}(125.0$ in.) $\times 266.70 \mathrm{~cm}$ (105. in.).

Gradel 8200 is 200 cenisters $635.00 \mathrm{~cm}(250.0$ in.) $\times 533.40 \mathrm{~cm}(210.0 \mathrm{in.}$ ).

Model B1800 is 1800 canisters, or a full-basin bay (about $1 / 3$ of entire basin), $1905.00 \mathrm{~cm}(750.0 \mathrm{fn}.) \times 1600.20 \mathrm{~cm}(630$. in.). 
The major consideration is the normal operation of lifting one irradiated fuel storage canister above the static array. The calculated dose rate increases due to a second lifted canister or water temperature change are small and are only minor considerations.

\subsubsection{Active Storage Array ISOSHLD-II Model}

The active storage array ISOSHLD-II dose rate is calculated by summing the dose rate for the entire static fuel storage array with that of a single canister suspended $91.44 \mathrm{~cm}(3 \mathrm{ft})$ above the array for movement and repositioning. The $91.44-\mathrm{cm}(3-\mathrm{ft})$ distance is measured from the top of the lid in the canister array to the top of the lid of the suspended canister. A canister is $73.66 \mathrm{~cm}(29 \mathrm{in.})$ high, so $17.78 \mathrm{~cm}(7 \mathrm{in.})$ is allowed between the bottom of the suspended canister and the top of the canisters in the canister array. Figure 8 shows this situation of lifting a canister above the storage array to move it to another location.

The calculated dose rates are taken from Table 16 and reproduced in Table 17. The summing procedure is shown in Table 17. The single canister at $91.44 \mathrm{~cm}(3 \mathrm{ft})$ less water shielding than the static storage array contributes more to the dose rate than the entire static fuel storage array. Table 18 lists the active array ISOSHLD-II dose rates for all decay times.

Table 17. Active Storage Array Dose Rate Calculations (mR/h).

\begin{tabular}{|c|c|c|c|c|}
\hline \multicolumn{2}{|c|}{ Array depth } & $\begin{array}{c}\text { Canister } \\
\text { 91.44 cm (3 ft) } \\
\text { above array }\end{array}$ & $\begin{array}{c}\text { Static basin } \\
\text { storage array }\end{array}$ & Total \\
\hline 121.92 & 4 & 920.6 & 24.95 & 945.55 \\
\hline 152.40 & 5 & 97.32 & 2.566 & 99.886 \\
\hline 182.88 & 6 & 9.656 & 0.2794 & 9.9354 \\
\hline 213.36 & 7 & 0.9446 & 0.03312 & 0.97772 \\
\hline 243.84 & 8 & 0.09354 & 0.004407 & 0.097947 \\
\hline 274.32 & 9 & $9.603 \mathrm{E}-03$ & 6.700 E-04 & 1.027 E-02 \\
\hline 304.80 & 10 & $1.051 \mathrm{E}-03$ & 1.154 E-04 & 1.166 E-03 \\
\hline 335.28 & 11 & 1.269 E-04 & 2.191 E-05 & 1.488 E-04 \\
\hline 365.76 & 12 & 1.735 E-05 & 4.444 E-06 & 2.179 E-05 \\
\hline 396.24 & 13 & 2.704 E-06 & 9.401 E-07 & 3.644 E-06 \\
\hline 426.72 & 14 & 4.711 E-07 & 2.043 E-07 & 6.754 E-07 \\
\hline 457.20 & 15 & 8.902 E-08 & 4.520 E-08 & 1.342 E-07 \\
\hline 487.68 & 16 & 1.775 E-08 & 1.013 E-08 & 2.788 E-08 \\
\hline
\end{tabular}

NOTE: Reference date is January 31, 1995. 


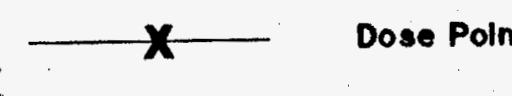

Alr $152.4 \mathrm{~cm}(5 \mathrm{ft})$

No
Water Shield

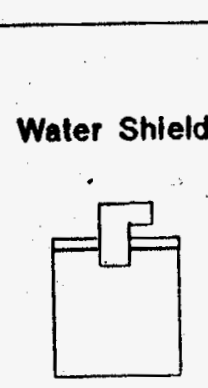

Alr $152.4 \mathrm{~cm}$ is

Single canister

storage location.
Dose Polnt

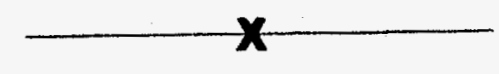

Air $152.4 \mathrm{~cm} \mathrm{(5} \mathrm{fO)}$

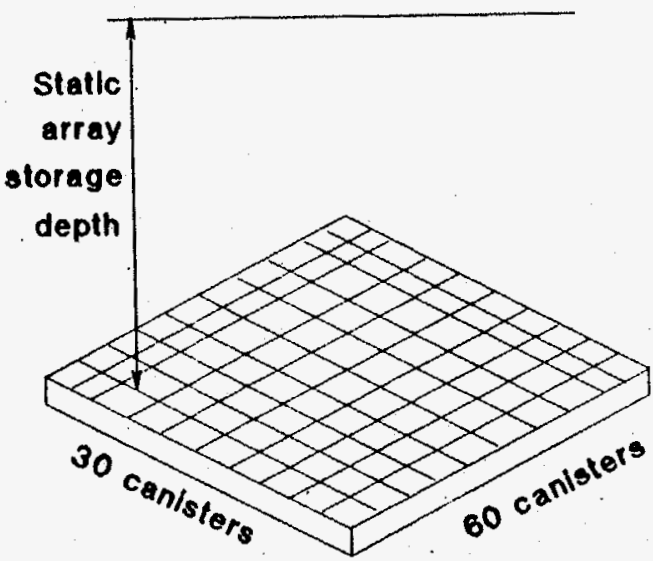

One-third of fuel storage basin

is static storage array.
Dose Point

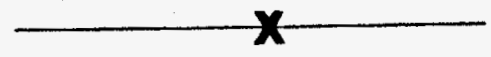

Alf $152.4 \mathrm{~cm} \mathrm{(5} \mathrm{f)}$

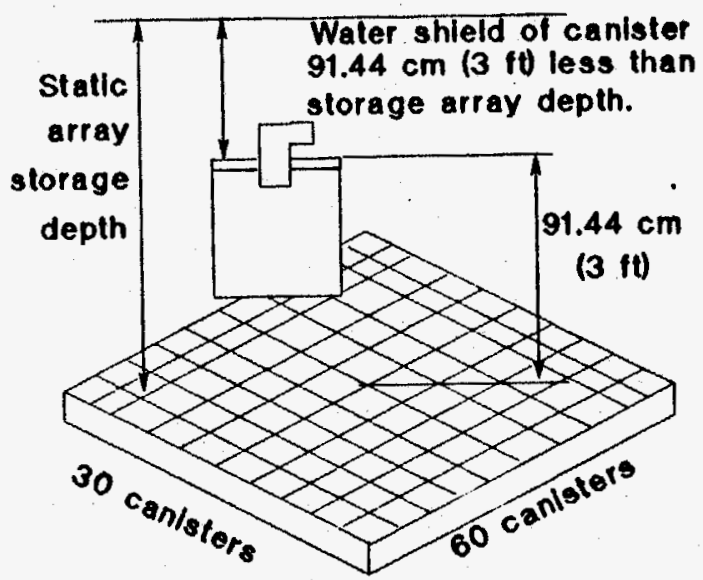

Active fuel storage array has

one canister above the

static fuel storage array

at $91.44 \mathrm{~cm}(3 \mathrm{ft})$ less shielding

than storage array. 
WHC-SD-NR-ER-105 Rev. O

Table 18. Active Storage Array ISOSHLD-II Dose Rates.

\begin{tabular}{|c|c|c|c|c|c|}
\hline \multicolumn{2}{|c|}{ Array depth } & \multirow{2}{*}{$\begin{array}{c}\text { Reference } \\
\text { date }\end{array}$} & \multirow{2}{*}{$+1,000$ days } & \multirow{2}{*}{$+3,000$ days } & \multirow{2}{*}{$+5,000$ days } \\
\hline $\mathrm{cm}$ & $\mathrm{ft}$ & & & & \\
\hline 121.92 & 4 & 945.55 & 881.66 & 772.11 & 678.38 \\
\hline 152.40 & 5 & 99.886 & 93.001 & 81.343 & 71.4 \\
\hline 182.88 & 6 & 9.9354 & 9.228 & 8.0509 & 7.0567 \\
\hline 213.36 & 7 & 0.97772 & 0.90412 & 0.78537 & 0.68664 \\
\hline 243.84 & 8 & $9.795 E-02$ & $8.983 \quad E-02$ & 7.742 E-02 & $6.742 \mathrm{E}-02$ \\
\hline 274.32 & 9 & $1.027 \quad E-02$ & $9.278 E-03$ & 7.891 E-03 & $6.823 E-03$ \\
\hline 304.80 & 10 & $1.166 \mathrm{E}-03$ & 1.027 E-03 & 8.542 E-04 & 7.306 E-04 \\
\hline 335.28 & 11 & $1.488 \mathrm{E}-04$ & $1.262 \quad E-04$ & $1.015 \mathrm{E}-04$ & 8.552 E-05 \\
\hline 365.76 & 12 & $2.179 \mathrm{E}-05$ & 1.766 E-05 & $1.364 \mathrm{E}-05$ & $1.129 E-05$ \\
\hline 396.24 & 13 & 3.644 E-06 & $2.824 \quad E-06$ & $2.094 \mathrm{E}-06$ & $1.704 E-06$ \\
\hline 426.72 & 14 & 6.754 E-07 & $5.041 \mathrm{E}-07$ & 3.614 E-07 & $2.903 \quad E-07$ \\
\hline 457.20 & 15 & 1.342 E-07 & $9.734 \mathrm{E}-08$ & $6.799 \mathrm{E}-08$ & $5.414 \quad E-08$ \\
\hline 487.68 & 16 & $2.788 E-08$ & $1.977 \mathrm{E}-08$ & $1.355 E-08$ & $1.073 E-08$ \\
\hline
\end{tabular}

NOTES:

One canister $91.44 \mathrm{~cm}(3 \mathrm{ft})$ above static array.

Reference date is January 31, 1995.

Calculated dose rates in $\mathrm{mR} / \mathrm{h}$.

\subsubsection{Storage Array with Multiple Elevated Canisters}

This ISOSHLD-II calculation was performed with only one canister of irradiated N Reactor fuel raised $91.44 \mathrm{~cm}(3 \mathrm{ft}$ ) above the static canister array for the maximum dose rate calculation. Other raised canisters in other basin locations would add an incremental gamma ray dose rate to this calculated maximum dose rate. Two representative calculations will be performed: (1) a second raised canister in an adjacent slot in the basin grating, and (2) a second raised canister in the next to adjacent slot. Two effects considered are increased distance and increased attenuation in the water shield.

First, the second raised canister is in the adjacent grating slot. The static basin array at $243.84 \mathrm{~cm}(8 \mathrm{ft})$ and the raised canister at $152.40 \mathrm{~cm}$ $(5 \mathrm{ft}$ ) below the water surface. There is $152.40 \mathrm{~cm}(5 \mathrm{ft})$ air above the water surface to the calculated dose point for a distance of $304.80 \mathrm{~cm}(10 \mathrm{ft})$ total. (152.40 cm [5 ft] water $+152.40 \mathrm{~cm}[5 \mathrm{ft}]$ air $=304.80 \mathrm{~cm}[10 \mathrm{ft}]$. 
The distance between two adjacent slots in the basin grating is $100.489 \mathrm{~cm}$. $(2 *[1925 / 32$ in. $]=39.5625$ in. $=100.489 \mathrm{~cm}$.$) The distance from the second$ raised canister will be:

$$
d=\sqrt{\left((120 . \text { in. })^{2}+(39.5625 \text { in. })^{2}\right)}=126.35 \mathrm{in.}
$$

The dose rate from this second canister will be diminished by distance to $(120 . / 126.3534384)^{2}=0.9020$ of the contribution of the canister directly below the dose point. The water shielding will be increased by:

$$
\Delta d=60.0 *(126.35 / 120.0)-60.0=3.175 \mathrm{in} .=8.0645 \mathrm{~cm}
$$

which would diminish the dose rate because of increased water shielding by a factor of 2.577:

$$
(3.175 / 12.0) *(0.09354 / 9.603 E-3)=0.26458 * 9.7407=2.577 .
$$

The combination of distance and attenuation gives $0.9020 / 2.577=0.35$ for diminishment of dose rate due to the second canister raised $91.44 \mathrm{~cm}$ (3 ft) above the basin array. Then a total dose rate would be:

$$
0.097947+(0.09354 * 0.35)=0.097947+0.032739=0.130686 \mathrm{mR} / \text { hour } \text {. }
$$

So, a second canister raised $91.44 \mathrm{~cm}(3 \mathrm{ft})$ above the static array, at closest approach in the adjacent grating slot, represents an increase to $133 \%$ of the active basin array situation. $(100 \% *[0.130686 / 0.097947]=133 \%$.)

Next, the second raised canister is in the next to adjacent grating siot. The static array is at $243.84 \mathrm{~cm}(8 \mathrm{ft})$ and the raised canister at $152.40 \mathrm{~cm}$ $(5 \mathrm{ft})$ below the water surface. $([8-3]=5 \mathrm{ft}$.$) There is 152.40 \mathrm{~cm}(5 \mathrm{ft})$ air above the water surface to the calculated dose point for a distance of $304.80 \mathrm{~cm}(10 \mathrm{ft})$ tota $7 .(152.40 \mathrm{~cm}[5 \mathrm{ft}]$ water $+152.40 \mathrm{~cm}[5 \mathrm{ft}]$ air $=$ $304.80 \mathrm{~cm}$ [10 ft].) The distance between next to adjacent slots in the basin grating is $200.9775 \mathrm{~cm}(79.125$ in.). (4* [19 25/32 in.] $=79.125$ in.) The distance from the second raised canister will be:

$$
d=\sqrt{(120 . \text { in. })^{2}+(79.125 \text { in. })^{2}}=143.74 \text { in. }
$$

The dose rate from this second canister will be diminished by distance to 0.6970 of the contribution of the canister directly below the dose point. $(120 . / 143.7385322)^{2}=0.6970$.) The water shielding will be increased by:

$$
\Delta d=60.0 *(143.74 / 120.0)-60.0=11.87 \mathrm{in} .=30.15 \mathrm{~cm}
$$


which would diminish the dose rate because of increased water shielding by a factor of 9.635:

$$
(11.87 / 12.0) *(0.09354 / 9.603 E-3)=0.98917 * 9.7407=9.635 .
$$

The combination of distance and attenuation gives $0.6970 / 9.635=0.072$ for diminishment of dose rate due to the second canister raised $91.44 \mathrm{~cm}(3 \mathrm{ft})$ above the basin array. Then a total dose rate would be:

$$
0.097947+(0.09354 * 0.072)=0.097947+0.006735=0.10468 \mathrm{mR} / \text { hour } \text {. }
$$

So, a second canister raised $91.44 \mathrm{~cm}(3 \mathrm{ft})$ above the static array, at closest approach in the next to adjacent grating slot, represents an increase to $107 \%$ of the active basin array situation. $(100 \% *[0.10468 / 0.097947]=$ 107\%.)

In conclusion, except for closest approach, which may increase the calculated dose rate by about $1 / 3$, additional moving canisters in the basin are insignificant based on dose rate considerations.

Because of the large size of the basin compared to an expected closest approach of two canisters being moved, and that fact that an increase in gamma ray dose rate of $33 \%$ or $7 \%$ is expected for the close approach of two moving canisters suspended $91.44 \mathrm{~cm}(3 \mathrm{ft})$ above the static array, there is no proposed operational limit to the number of canisters which may be moved in the basin at one time.

\subsubsection{Temperature Effect on Water Density and Radiation Shielding}

Water density changes with temperature and less dense water can be expected to have diminished water shielding effect. K Basins water temperature is maintained between $5.5{ }^{\circ} \mathrm{C}$ to $32.2{ }^{\circ} \mathrm{C}\left(42{ }^{\circ} \mathrm{F}\right.$ to $\left.90{ }^{\circ} \mathrm{F}\right)$. The difference in water quantity for a fixed water depth will be used to infer radiation doṣe rate increase.

A calculation of change of water shielding thickness can be derived from Table 16, model Bl: $4 \mathrm{ft}$ dose rate $0.9446 \mathrm{mR} / \mathrm{h}, 5 \mathrm{ft}$ dose rate $0.09354 \mathrm{mR} / \mathrm{h}$. Water specific volume changes approximately $0.5 \%$ when the temperature changes from $5.5^{\circ} \mathrm{C}$ to $32.2{ }^{\circ} \mathrm{C}\left(42{ }^{\circ} \mathrm{F}\right.$ to $\left.90^{\circ} \mathrm{F}\right)$. The decrease of water mass in $152.4 \mathrm{~cm}$ $(5 \mathrm{ft})$ of water will be converted into an equivalent decrease in linear distance while keeping the water density fixed. The equivalent decrease in water shield thickness will be converted into an increase in dose rate from using ISOSHLD-II calculated dose for two different water shield thicknesses.

An example of this increase in radiation dose rate due to temperature dependent water density decrease will be given before tabulation in Table 19. The $152.4 \mathrm{~cm}(5.0 \mathrm{ft})$ water shield thickness is used as an example because this is the water shield above the single lifted canister for the static storage array at $243.84 \mathrm{~cm}(8 \mathrm{ft})$ water shield thickness. For $5.5^{\circ} \mathrm{C}\left(42{ }^{\circ} \mathrm{F}\right)$, the specific volume of water is $1.0000 \mathrm{~cm}^{3} / \mathrm{g}\left(0.016019 \mathrm{ft}^{3} / 1 \mathrm{~b}\right)$, and at $21.1{ }^{\circ} \mathrm{C}$ $\left(70^{\circ} \mathrm{F}\right)$, the specific volume of water is $1.0020 \mathrm{~cm}^{3} / \mathrm{g}\left(0.016050 \mathrm{ft}^{3} / \mathrm{lb}\right)$. 
Table 19. Radiation Dose Rate Increase Due to Water Temperature.

\begin{tabular}{|c|c|c|c|c|c|c|}
\hline \multicolumn{2}{|c|}{$\begin{array}{c}\text { Water } \\
\text { temperature }\end{array}$} & \multicolumn{2}{c|}{$\begin{array}{c}\text { Water } \\
\text { specific volume }\end{array}$} & \multicolumn{2}{c|}{$\begin{array}{c}\text { Equivalent } \\
\text { decrease of } \\
\text { water shield }\end{array}$} & $\begin{array}{c}\text { Increase of } \\
\text { radiation dose } \\
\text { rate }\end{array}$ \\
\hline${ }^{\circ} \mathrm{C}$ & ${ }^{\circ} \mathrm{F}$ & $\mathrm{cm}^{3} / \mathrm{g}$ & $\mathrm{ft}^{3} / 1 \mathrm{~b}$ & $\mathrm{~cm}$ & in. & \\
\hline 5.5 & 42 & 1.0000 & 0.016019 & 0.0000 & 0.0000 & $+0.00 \%$ \\
\hline 10.0 & 50 & 1.0003 & 0.016023 & 0.0380 & 0.0150 & $+1.26 \%$ \\
\hline 15.6 & 60 & 1.0009 & 0.016033 & 0.1331 & 0.0524 & $+4.41 \%$ \\
\hline 21.1 & 70 & 1.0020 & 0.016050 & 0.2944 & 0.1159 & $+9.75 \%$ \\
\hline 26.7 & 80 & 1.0033 & 0.016072 & 0.5026 & 0.1979 & $+16.65 \%$ \\
\hline 32.2 & 90 & 1.0050 & 0.016099 & 0.7573 & 0.2982 & $+25.09 \%$ \\
\hline
\end{tabular}

NOTES: Equivalent water shield thickness decrease calculated. Equivalent radiation dose rate increase calculated.

Situation: one canister at $152.4 \mathrm{~cm}(5 \mathrm{ft})$ water depth. Reference water temperature is $5.5^{\circ} \mathrm{C}\left(42^{\circ} \mathrm{F}\right)$.

The equivalent decrease in water shield thickness for $152.4 \mathrm{~cm}(5 \mathrm{ft})$ of water and $5.5{ }^{\circ} \mathrm{C}$ to $21.1{ }^{\circ} \mathrm{C}\left(42{ }^{\circ} \mathrm{F}\right.$ to $\left.70^{\circ} \mathrm{F}\right)$ temperature increase is:

$$
(1.0-[0.016019 / 0.016050]) \times 60 \mathrm{in.}=0.1159 \mathrm{in} \text {. }
$$

The effective fractional increase in ISOSHLD-II calculated dose rate is:

$$
(0.1159 \mathrm{in.} / 12.0 \mathrm{in}) \times(0.9446 \mathrm{mR} / \mathrm{h} / 0.09354 \mathrm{mR} / \mathrm{h})=0.0975=9.75 \% \text {. }
$$

The results of Table 19, along with the assumption that $K$ Basins will be normally operated with water temperature less than $15{ }^{\circ} \mathrm{C}\left(60^{\circ} \mathrm{F}\right)$ where the increase in radiation dose rate would be less than $5 \%$. In the most extreme situation of $K$ Basins water temperature increasing to $32^{\circ} \mathrm{C}\left(90^{\circ} \mathrm{F}\right)$, the equivalent decrease of water shield at $152.4 \mathrm{~cm}(5 \mathrm{ft})$ thickness would be only $0.76 \mathrm{~cm}(0.3 \mathrm{in.})$, which is a minor concern compared to the operational limit of water level: $490 \pm 15 \mathrm{~cm}(16.0 \pm 0.5 \mathrm{ft})$.

\subsection{MINIMUM HATER SHIELD REQUIREMENT}

The minimum water shield requirement, consistent with WHC-CM-4-9, will now be calculated. This Westinghouse company policy manual was derived from DOE Orders 5480.11 and 6430.1A.

Shielding that meets these design criteria will also meet the ALARA objectives for the Compacted Fuel Storage Facility for storing irradiated $N$ Reactor fuel for an indefinite time. The candidate storage facility is the KW Reactor irradiated fuel storage basin.

The shield design shall be based on Table 1 from Section 8 of WHC-CM-4-9. Dose rates in all cases are at the point of exposure where an individual will actually be working. 
The initial design level in Table 20 for each zone category shall be used for the design criteria. Lower levels are desirable using the ALARA principle.

Table 20. Shield Design Criteria (from Section 8 of WHC-CM-4-9).

\begin{tabular}{|l|l|c|c|}
\hline $\begin{array}{c}\text { Zone } \\
\text { category }\end{array}$ & \multicolumn{1}{|c|}{$\begin{array}{c}\text { Access time } \\
\text { allowed }\end{array}$} & $\begin{array}{c}\text { Initial } \\
\text { design level } \\
\text { (mrem per } \\
\text { hour) }\end{array}$ & $\begin{array}{c}\text { Maximum } \\
\text { (mrem per } \\
\text { hour) }\end{array}$ \\
\hline Uncontrolled Area & Full time & 0.05 & 0.1 \\
\hline Controlled Area 1 & Full time & 0.2 & 0.5 \\
\hline Controlled Area 2 & Less than 1 hour per day & 2 & 5 \\
\hline Controlled Area 3 & Less than 1 hour per week & 10 & 20 \\
\hline Controlled Area 4 & Less than 10 hours per year & 50 & 100 \\
\hline Controlled Area 5 & No normal access permitted & $>100$ & -- \\
\hline
\end{tabular}

The radiation shielding material in this calculation is basin water, although credit is taken for the uranium and zirconium in the fuel elements and the stainless steel of the Mark II canisters. The basin water surrounds the radiation source.

The canister inventory of irradiated $N$ Reactor fuel is provided in Appendix A. The fuel is identified by fuel types (enrichments), and average fuel exposure. The radionuclide content and subsequent nuclear radiation were determined by ISOSHLD-II. The highest exposure fuel, the key with 16.333 wt\% ${ }^{240} \mathrm{Pu}$, was used for shielding calculations.

The $2 \mathrm{mR} / \mathrm{h}$ is the radiation dose rate requirement used to calculate "Controlled Area 2" water shield thickness. The $0.2 \mathrm{mR} / \mathrm{h}$ is radiation dose rate requirement used to calculate "Controlled Area 1" water shield thickness.

Interpolation takes advantage that the ISOSHLD-II calculated dose rate appears linear on a log-linear graph. That is the logarithm (dose rate) is linear when plotted versus the water shield thickness.

The formula for linear interpolation is:

$$
f(x)=\left(\left(x-x_{2}\right) /\left(x_{1}-x_{2}\right)\right) * f\left(x_{1}\right)+\left(\left(x-x_{1}\right) /\left(x_{2}-x_{1}\right)\right) * f\left(x_{2}\right) .
$$

Using $x=\ln (2.0 \mathrm{mR} / \mathrm{h})$, and choose two points on each side, $x_{1}=\ln (9.9354 \mathrm{mR} / \mathrm{h}), f\left(x_{1}\right)=6 \mathrm{ft}$, $x_{2}=\ln (0.97772 \mathrm{mR} / \mathrm{h}), f\left(x_{2}\right)=7 \mathrm{ft}$.

The calculation for $2 \mathrm{mR} / \mathrm{h}$ water shield thickness is:

$$
\begin{aligned}
f(x) & =((\ln (2.0)-\ln (0.97772)))((\ln (9.9354)-\ln (0.97772))) *(6 \mathrm{ft}) \\
& +((\ln (2.0)-\ln (9.9354)) /(\ln (0.97772)-\ln (9.9354))) *(7 \mathrm{ft}) \\
f(x) & =0.30866 *(6 \mathrm{ft})+0.69134 *(7 \mathrm{ft})=6.6913 \mathrm{ft}=6 \mathrm{ft} 8.3 \mathrm{in} .
\end{aligned}
$$


Finally, the result is:

$2.0 \mathrm{mR} / \mathrm{h}$ controlled area 2 minimum water shield thickness $=6 \mathrm{ft} 9 \mathrm{in}$.

Minimum water shield thickness calculations for $0.2 \mathrm{mR} / \mathrm{h}=7 \mathrm{ft} 9 \mathrm{in}$.

Similarly, minimum water shielding thicknesses can be calculated for any design level radiation dose rate and at different decay times after the reference date. These distances were measured from the top surface of the canister lid to the water surface, which is $5 \mathrm{ft}$ below the calculated dose point. Figure 9 depicts these distances for minimum water shielding.

Inspecting the Mark II canister dimensions reveals the following:

Canister barrel length

Bottom plate bottom to canister barrel bottom

Bottom plate bottom to canister barrel top

Canister lid groove to canister lid top surface

Bottom plate bottom to canister lid top surface

$$
26.88 \text { in. }
$$$$
+0.12 \mathrm{in} .
$$$$
=27.00 \mathrm{in} \text {. }
$$$$
\pm 0.375 \text { in. }
$$

$=27.375 \mathrm{in}$. following:

Inspecting the Mark II canister fuel positioning information reveals the

Bottom plate thickness

Bottom plate dimple

(minimum specification 0.03 in.)

MKIV fuel element maximum length

MKIV fuel element end cap thickness

Therefore, MKIV endcap top to canister lid bottom
0.5 in.

0.055 in.

26.1 in.

0.19 in.

0.22 in.

The Kaiser engineering study considered two stacking options. Option A (ES-N040-SO3) has the canisters stacked on top of each other, while the

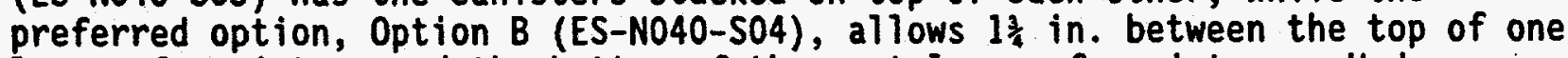
layer of canisters and the bottom of the next layer of canisters. Under option B the distance from the basin concrete surface to the top of the upper lid is:

\begin{tabular}{|c|c|c|}
\hline $\begin{array}{l}\text { Canister to lid top } \\
\text { Option B Spacing } \\
\text { Canister full height } \\
\text { Option B Spacing } \\
\text { Canister full height } \\
\text { Bottom plate } \\
\text { Total }\end{array}$ & $\begin{aligned} & 27.375 \mathrm{in.} \\
+ & 1.750 \mathrm{in.} \\
+ & 29.000 \mathrm{in.} \\
+ & 1.750 \mathrm{in} . \\
+ & 29.000 \mathrm{in.} \\
+ & 0.500 \mathrm{in} . \\
= & 89.375 \mathrm{in} .\end{aligned}$ & $\begin{array}{l}\text { (H-1-46215 Sheets 3, 4, and 5) } \\
\text { (ES-N040-S04 Section B) } \\
\text { (H-1-46215 Sheet 1) } \\
\text { (ES-N040-S04 Section B) } \\
\text { (H-1-46215 Sheet 1) } \\
\text { (ES-N040-S03 Detai1 3) } \\
7 \mathrm{ft} 5.375 \text { in. }=227.0125 \mathrm{~cm} .\end{array}$ \\
\hline
\end{tabular}


Figure 9. Minimum Water Thickness Basin Geometry.

(One Canister $91.44 \mathrm{~cm}$ [3 ft] Above Triple-Stacked Static Basin Model.)

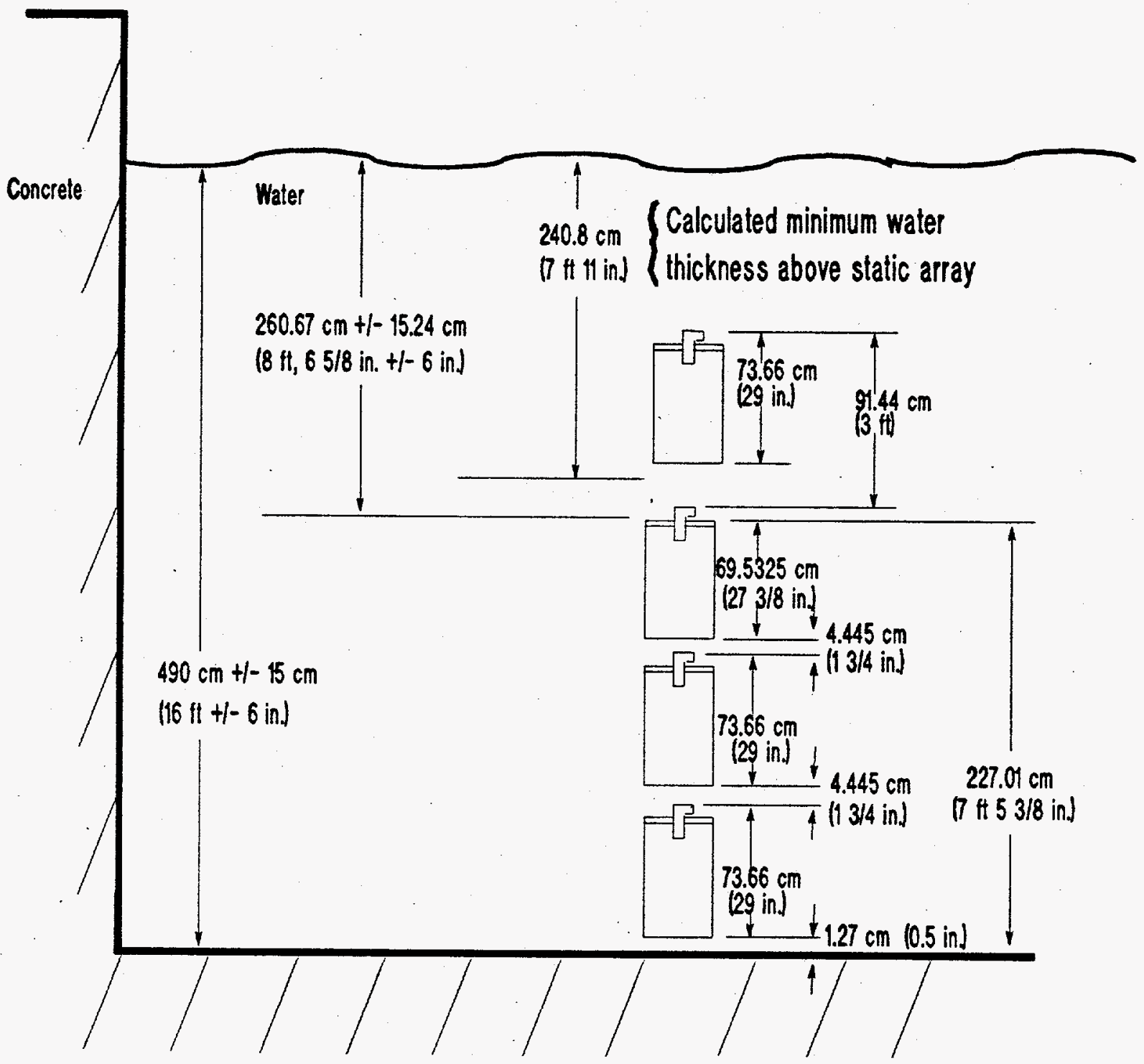

Design (ES-N040-S03/S04) water thickness above static array is $260.67+1-15.24 \mathrm{~cm}$ $18 \mathrm{ft}, 65 / 8 \mathrm{in.}+/-6 \mathrm{in}$.). Active basin shielding calculations allowed for a single canister $91.44 \mathrm{~cm}(3 \mathrm{ft})$ above the static canister array. The active basin shielding calculations determined the minimum required water thickness above the static canister array to be $240.8 \mathrm{~cm}(7 \mathrm{ft}, 11 \mathrm{in}$.). 


\subsection{ISOSHLD CODE CONPARISON}

\subsection{PURPOSE OF COMPARISON}

This study was performed with ISOSHLD-II, yet other ISOSHLD versions exist. ISO-PC (custodian is Paul Rittman) has corrected many previous errors, some of which still exist in ISOSHLD-II. Documentation exists for ISO-PC, which is now version 1.9. ISOSHLD. 4.0 (custodian is Frank Schmittroth) is undergoing major modifications with buildup and attenuation libraries derived from recently available information.

\subsection{SCOPE OF COMPARISON}

The basic concern in this shielding study is the attenuation of ${ }^{137} \mathrm{Cs}$ gamma rays (661.7 keV) through water shielding with deep penetration. This situation, originally calculated in mode 1 using ISOSHLD-II, then changed to mode 2 by using only 27 isotopes ( 550 isotopes are in the RIBD 1ibrary). ISO-PC does not have RIBD for the mode 1 calculation, so both ISO-PC and ISOSHLD 4.0 were run using mode 2 . The ${ }^{137} \mathrm{Cs}$ isotope is dominant, and only deep penetration in the water shield is considered, and only the rectangular geometry option is used, so this is not a comprehensive ISOSHLD comparison. The case used for comparison purposes is model B1800 for the full static fuel storage array.

\subsection{RESULTS OF ISOSHLD COMPARISON}

ISOSHLD calculated dose rate at $152.40 \mathrm{~cm}(5 \mathrm{ft})$ above the water surface from 1,800 canister irradiated fuel static storage array was calculated are graphed in Figure 10 covering water depths between $30.48 \mathrm{~cm}(1 \mathrm{ft})$ and $304.80 \mathrm{~cm}(10 \mathrm{ft})$. On this scale, there does not appear to be much difference between the ISOSHLD versions for calculated water shield thickness. Figure 11 shows more detail by covering only water depths between $91.44 \mathrm{~cm}(3 \mathrm{ft})$ and $228.60 \mathrm{~cm}(7.5 \mathrm{ft})$. The main feature is that ISOSHLD 4.0 , with more recent build-up factors and attenuation coefficients consistently calculates higher dose rates in this geometry.

Figure 12 depicts the ratio of dose rates calculated using ISOSHLD 4.0 and ISOSHLD-II. For this document, the significant portion of this graph is the $152.40 \mathrm{~cm}(5 \mathrm{ft})$ to $243.84 \mathrm{~cm}(8 \mathrm{ft})$ depth. The $243.84 \mathrm{~cm}(8 \mathrm{ft})$ depth is significant because it is the static fuel array minimum calculated depth. The $152.40 \mathrm{~cm}(5 \mathrm{ft})$ depth is significant because it is the single canister suspended $91.44 \mathrm{~cm}(3 \mathrm{ft})$ above the static fuel array at minimum calculated depth. This figure indicates that the ISOSHLD-II calculated dose rate should be muitiplied by a 2.1 factor (ratio at $152.40 \mathrm{~cm}$ water shield).

Figure 13 depicts the ratio of dose rates calculated using ISO-PC version 1.9 and ISOSHLD-II. Both ISO-PC and ISOSHLD-II use original 1968 or earlier vintage attenuation and buildup data. ISO-PC has undergone more significant corrections than ISOSHLD-II, and is al so expected to be more correct than ISOSHLD-II. The comparison at $152.40 \mathrm{~cm}(5 \mathrm{ft})$ to $243.84 \mathrm{~cm}$ $(8 \mathrm{ft})$ water depth is that ISOSHLD-II calculates dose rates very close to ISO-PC or is conservative in this application. 

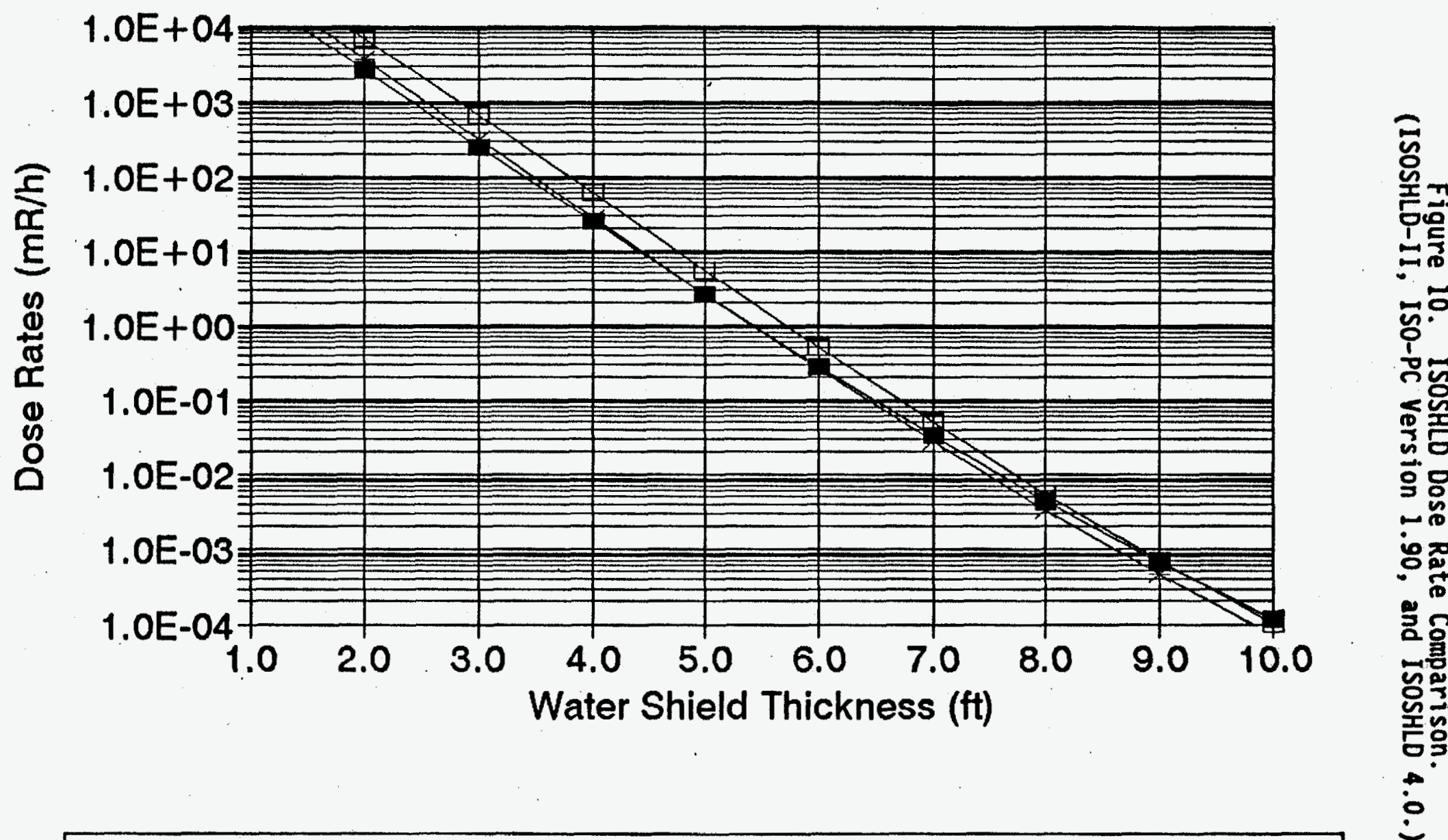


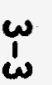

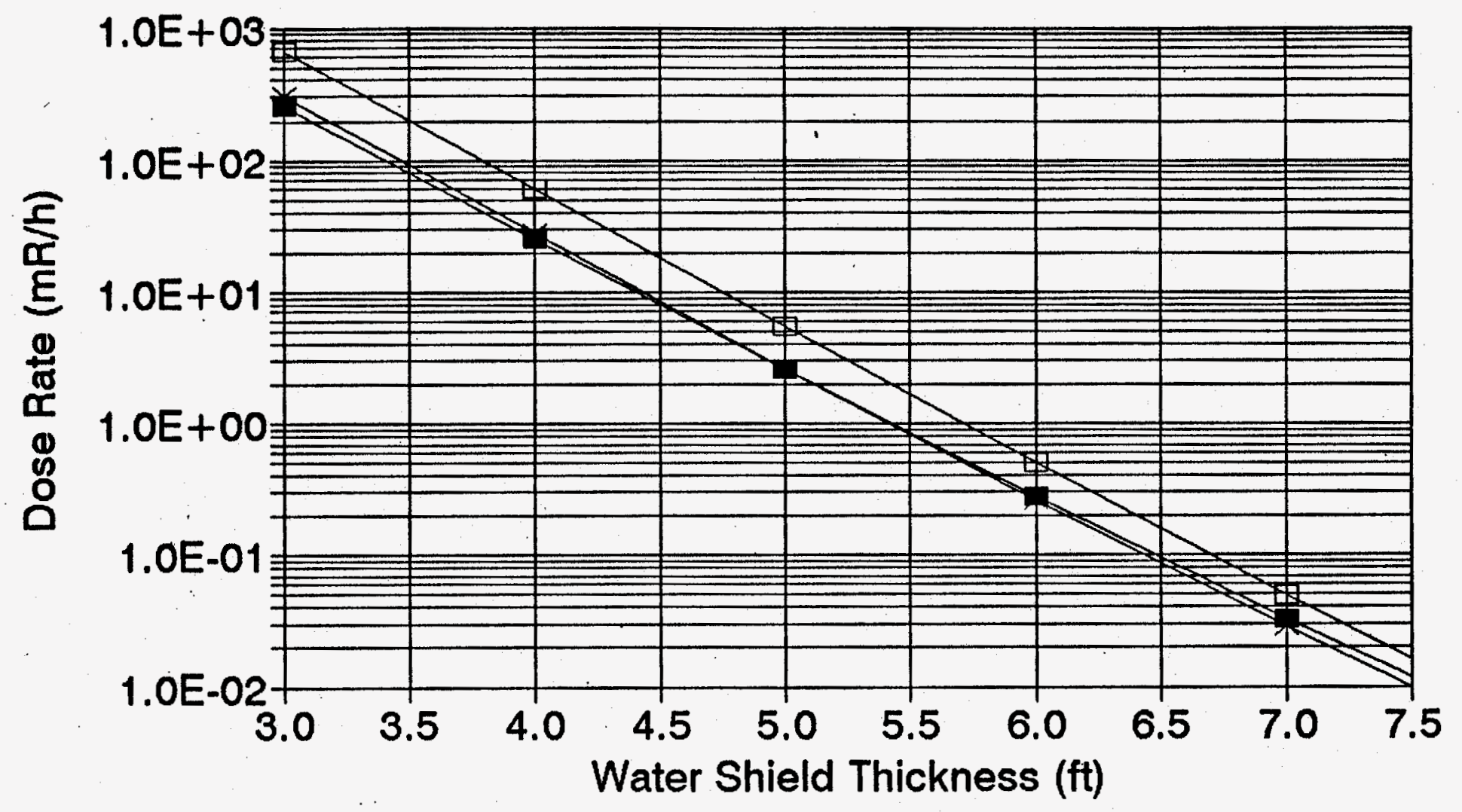

- ISO2-M1 $\quad$-ISO2-M2 $\quad *$ ISO-PC-M2 $\square-I S O 4-M 2$ 
WHC-SD-NR-ER-105 Rev. 0

Figure 12. ISOSHLD 4.0 to ISOSHLD-II Ratio. (ISOSHLD 4.0 over ISOSHLD-II.)

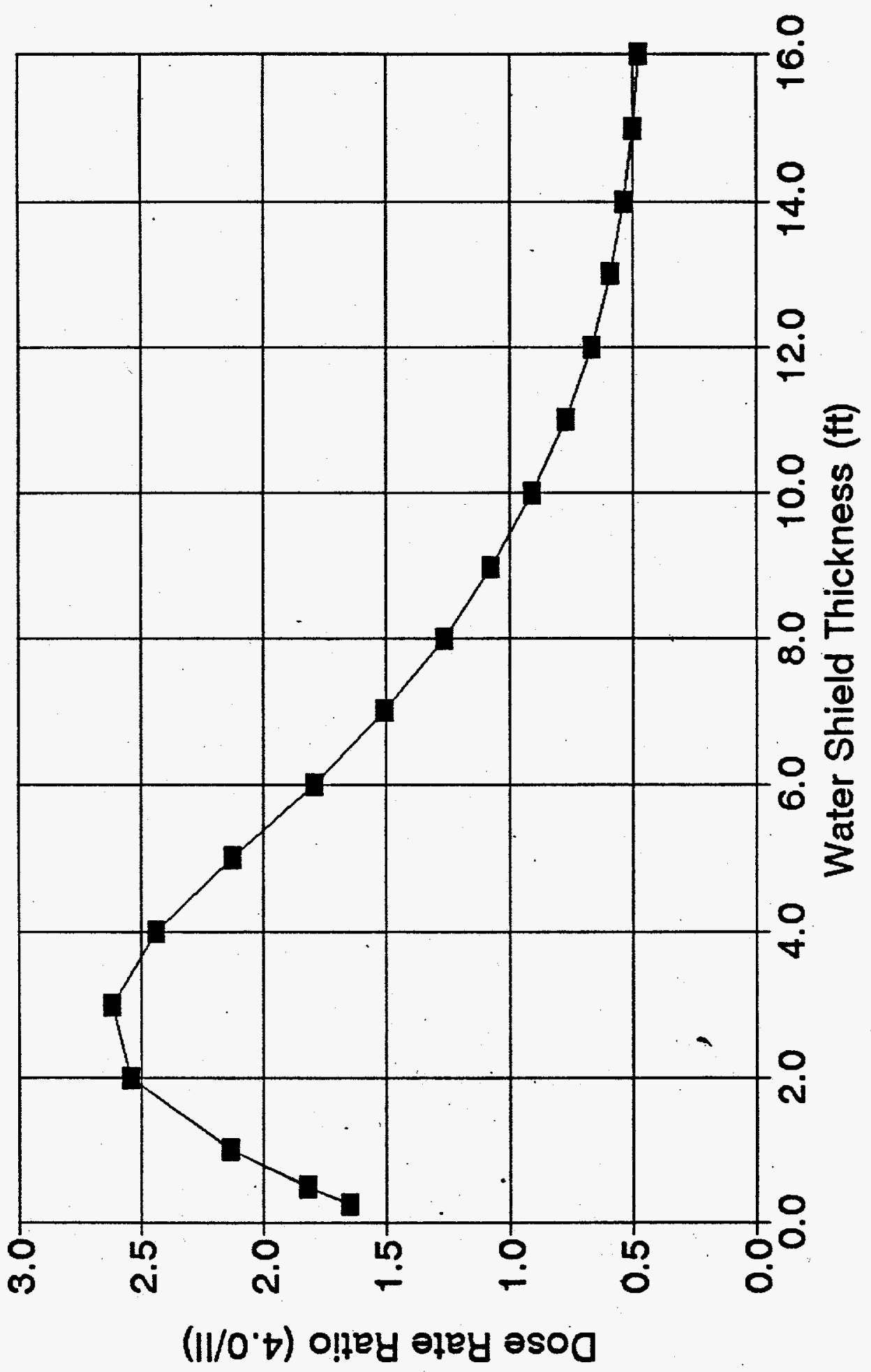


WHC-SD-NR-ER-105 Rev. 0

Figure 13. ISO-PC 1.90 to ISOSHLD-II Ratio. (ISO-PC 1.90 over ISOSHLD-II.)

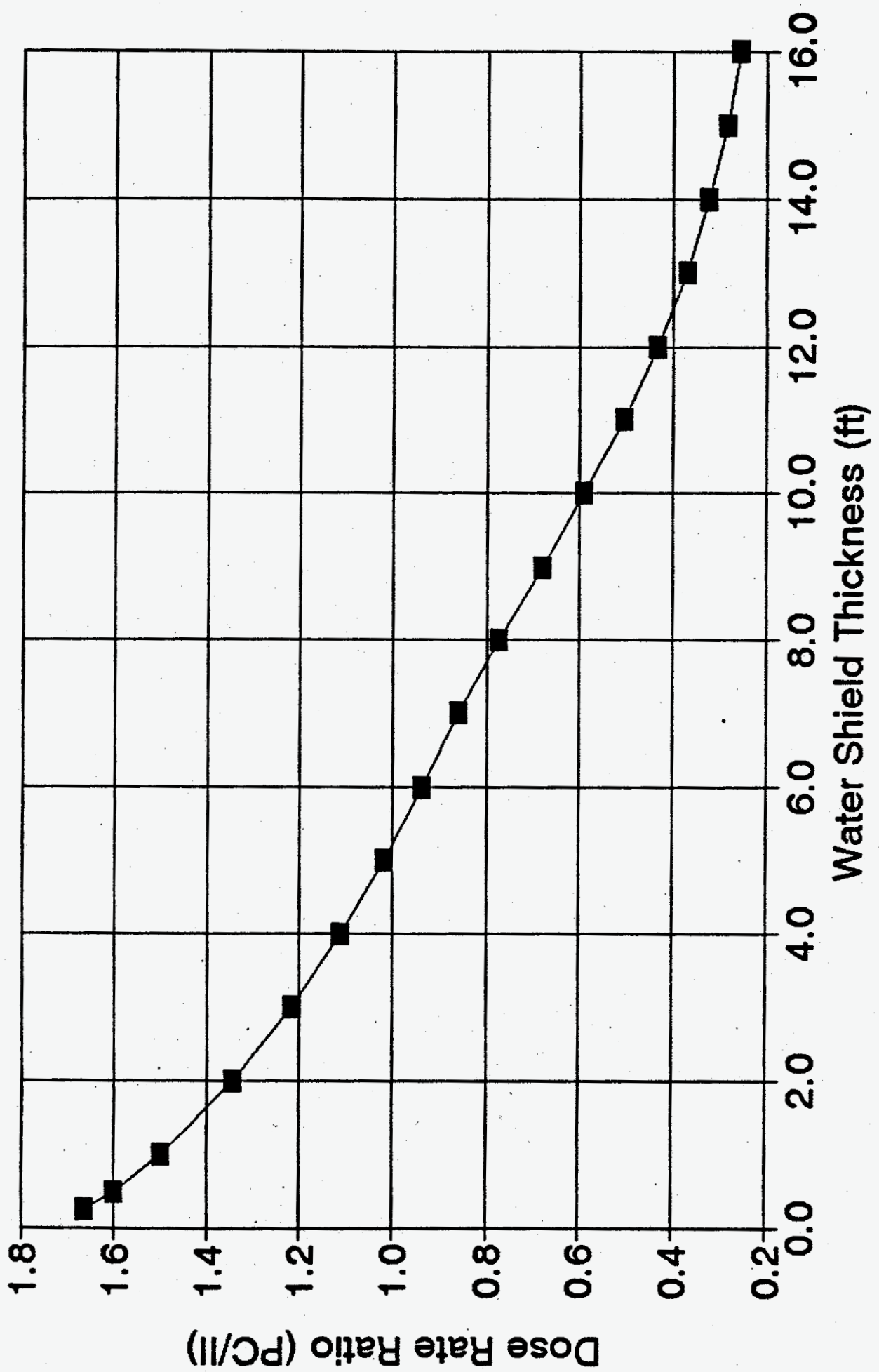


Figure 14 depicts the ratio of dose rates calculated using ISOSHLD 4.0 and ISO-PC version 1.90 .

Table 21 tabulates various ISOSHLD results. These values were used for the comparison figures. Notice at $30.48 \mathrm{~cm}(1 \mathrm{ft})$ distance, ISOSHLD 4.0 result is 2.14 times greater than the ISOSHLD-II result. $(60030 / 28070=2.14$. Table 5 compared experimental measurements to ISOSHLD-II adjusted to match the contact dose rate. The $30.48 \mathrm{~cm}(1 \mathrm{ft})$ water shield dose rate ratio for ISOSHLD-II/experimental measurements was 0.6222 . This indicated ISOSHLD-II should calculate 1.607 higher in order to match experimental measurements more accurately. $(1 / 0.6222=1.607$.$) This experimental comparison supports the$ accuracy of ISOSHLD 4.0 in this ${ }^{137}$ Cs gamma rays through water application.

Table 21. ISOSHLD Dose Rate Comparisons.

\begin{tabular}{|c|c|c|c|c|c|}
\hline \multicolumn{2}{|c|}{ Array depth } & \multicolumn{2}{|c|}{ ISOSHLD-II } & \multirow{2}{*}{$\begin{array}{l}\text { ISO-PC } \\
\text { Mode } 2\end{array}$} & \multirow{2}{*}{$\frac{\text { ISOSHLD } 4.0}{\text { Mode } 2}$} \\
\hline $\mathrm{cm}$ & $f t$ & Mode 1 & Mode 2 & & \\
\hline 7.62 & 0.25 & 172600 & 172600 . & 287300 . & 284200 . \\
\hline 15.24 & 0.50 & 93600. & 93590. & 149700. & 170700 . \\
\hline 30.48 & 1 & 28070 & 28070. & 42050. & 60030. \\
\hline 60.96 & 2 & 2621. & 2621. & 3523. & 6668. \\
\hline 91.44 & 3 & 252.1 & 252.1 & 307.4 & 660.5 \\
\hline 121.92 & 4 & 24.95 & 24.95 & 27.78 & 60.83 \\
\hline 152.40 & 5 & 2.566 & 2.566 & 2.619 & 5.452 \\
\hline 182.88 & 6 & 2.794 E-01 & $2.794 \quad E-01$ & 2.618.E-01 & 5.009 E-01 \\
\hline 213.36 & 7 & 3.312 E-02 & $3.312 \mathrm{E}-02$ & $2.837 \mathrm{E}-02$ & $4.979 \cdot E-02$ \\
\hline 243.84 & 8 & 4.407 E-03 & $4.407 \mathrm{E}-03$ & $3.404 \mathrm{E}-03$ & 5.582 E-03 \\
\hline 274.32 & 9 & $6.700 \mathrm{E}-04$ & $6.700 \mathrm{E}-04$ & $4.565 \mathrm{E}-04$ & 7.172 E-04 \\
\hline 304.80 & 10 & 1.154 E-04 & $1.154 \mathrm{E}-04$ & 6.802 E-05 & $1.045 \quad E-04$ \\
\hline 335.28 & 11 & $2.191 \mathrm{E}-05$ & $2.191 \mathrm{E}-05$ & $1.105 \mathrm{E}-05$ & $1.689 \mathrm{E}-05$ \\
\hline 365.76 & 12 & 4.444 E-06 & $4.444 \mathrm{E}-06$ & 1.917 E-06 & $2.960 \mathrm{E}-06$ \\
\hline 396.24 & 13 & $9.401 \quad E-07$ & $9.401 \mathrm{E}-07$ & 3.489 E-07 & 5.525 E-07 \\
\hline 426.72 & 14 & 2.043 E-07 & 2.043 E-07 & 6.592 E-08 & $1.087 \mathrm{E}-07$ \\
\hline 457.20 & 15 & $4.520 \mathrm{E}-08$ & $4.520 \mathrm{E}-08$ & $1.284 \mathrm{E}-08$ & $2.238 \mathrm{E}-08$ \\
\hline 487.68 & 16 & 1.013 E-08 & $1.013 \mathrm{E}-08$ & 2.567 E-09 & 4.817 E-09 \\
\hline
\end{tabular}

NOTES: Static array reference date is January 31, 1995. Calculated dose rates in $\mathrm{mR} / \mathrm{h}$. Model B1800 is being considered. 


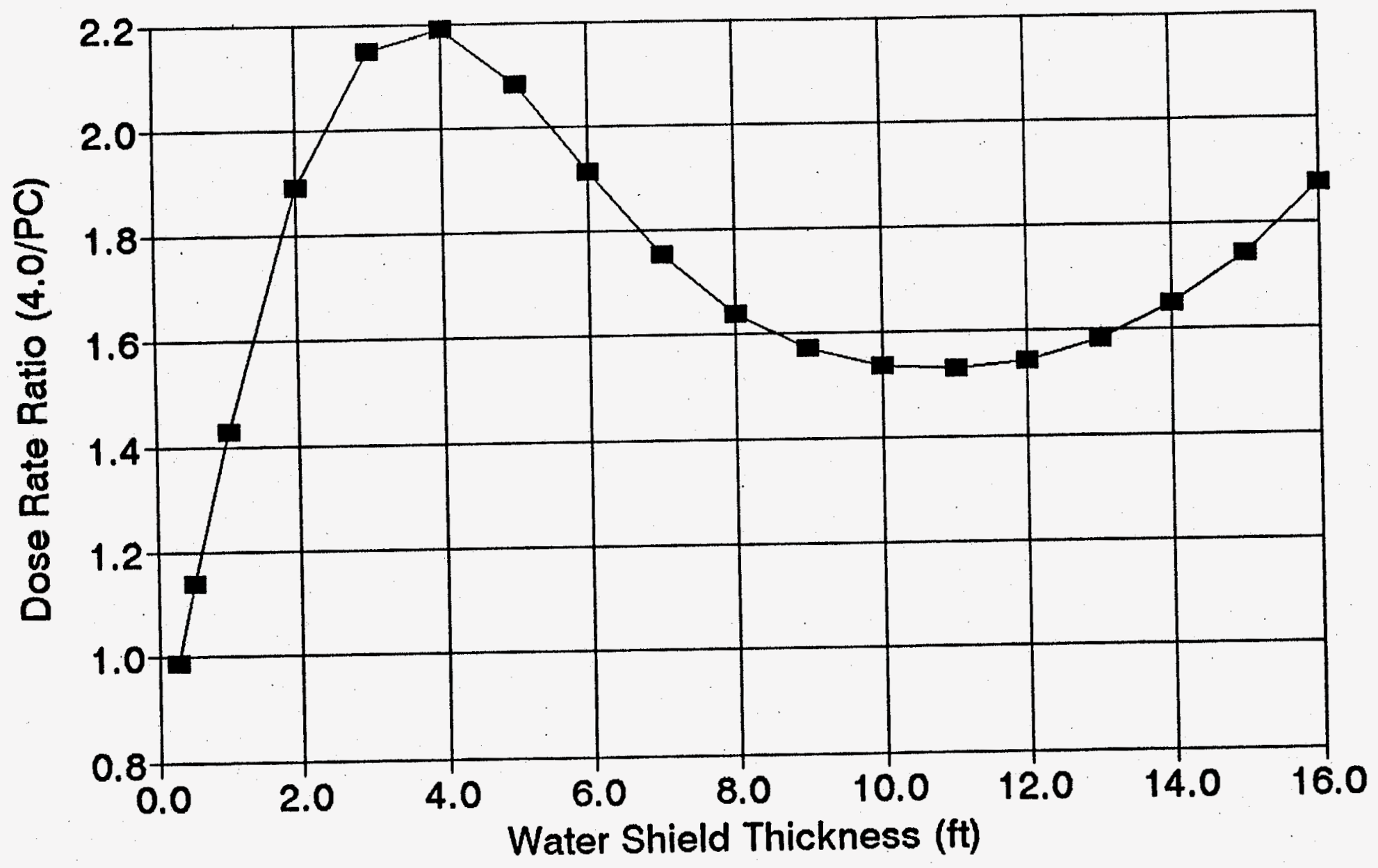

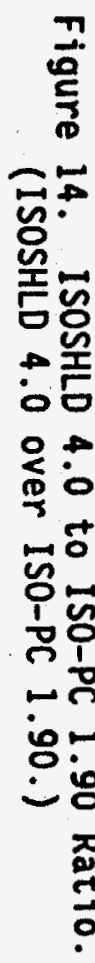




\subsection{CONCLUSION OF ISOSHLD COMPARISON}

ISOSHLD uses a point kernel method to calculate dose rates. This method adds up each point in the source, calculates the attenuation through all the intervening material and, for the dominant radiation shield, multiplies by a build-up factor. The buildup factor is used in order to accommodate the fact that the gamma rays are scattered but not absorbed. The gamma ray energy is still in the beam because it has not been absorbed. The ${ }^{137} \mathrm{Cs}$ gamma is 0.6617 $\mathrm{MeV}$, and attenuation coefficient at $0.650 \mathrm{keV}$ for water is $0.0832 \mathrm{~cm}^{-1}$. Thus a mean free path is $12.02 \mathrm{~cm}$. $\left(1.0 / 0.0832 \mathrm{~cm}^{-1}=12.02 \mathrm{~cm}\right.$.) Table 221 ists water buildup factors as a function of mean free paths.

Table 22. ANS-6.4.3 Water Buildup Factors (R).

\begin{tabular}{|c|c|c|c|}
\hline $\begin{array}{c}R \\
(\mathrm{mfp})\end{array}$ & $0.6 \mathrm{MeV}$ & $\begin{array}{c}\text { Depth } \\
(\mathrm{cm})\end{array}$ & $\begin{array}{c}\text { Depth } \\
(\mathrm{ft})\end{array}$ \\
\hline 5.0 & 15.6 & 60.1 & 1.972 \\
\hline 6.0 & 20.8 & 72.1 & 2.366 \\
\hline 7.0 & 26.7 & 84.1 & 2.760 \\
\hline 8.0 & 33.5 & 96.2 & 3.155 \\
\hline 10.0 & 49.3 & 120.2 & 3.943 \\
\hline 15.0 & 104. & 180.3 & 5.915 \\
\hline 20.0 & 179. & 240.4 & 7.887 \\
\hline 25.0 & 276. & 300.5 & 9.858 \\
\hline 30.0 & 395. & 360.6 & 11.830 \\
\hline 35.0 & 534. & 420.7 & 13.802 \\
\hline 40.0 & 695. & 480.8 & 15.773 \\
\hline
\end{tabular}

Calculated Range to $487.68 \mathrm{~cm}$ (16 ft) Water Depth.

Mean free paths converted to water thickness using $1 . / 0.0832 \mathrm{~cm}^{-1}=12.02 \mathrm{~cm}$.

Figure 12 depicts the ratio of dose rates calculated using ISOSHLD 4.0 and ISOSHLD-II. For this document, the significant portion of this graph is the $152.40 \mathrm{~cm}(5 \mathrm{ft})$ to $243.84 \mathrm{~cm}(8 \mathrm{ft})$ depth. The $152.40 \mathrm{~cm}(5 \mathrm{ft})$ depth is particularly significant because this is the depth of the single canister suspended $91.44 \mathrm{~cm}(3 \mathrm{ft})$ above the static fuel array at minimum calculated depth and the source of most of the calculated radiation dose rate for the active storage array. This figure indicates that the ISOSHLD-II calculated dose rate should be multiplied by 2.1 (ratio at $91.44 \mathrm{~cm}$ ( $5 \mathrm{ft}$ ) water shield). 
Table 22 is a demonstration that, at $152.40 \mathrm{~cm}$ ( $5 \mathrm{ft}$ ) to $243.84 \mathrm{~cm}$ $(8 \mathrm{ft})$ water shield thickness, the buildup factor is approximately 75 to 180 . This amounts to a correction in the point kernel method. With this perspective, and the improvement in measured data between approximately 1960 and June 1993, a calculated dose rate ratio between ISOSHLD-II and ISOSHLD 4.0 of 2.1 is not unreasonable. The additional water shielding required to reduce calculated dose rate by approximately 2.1 for the ${ }^{137} \mathrm{Cs}$ gamma ray is $6.4 \mathrm{~cm}$ (2.52 in.). $((5 \mathrm{ft}-4 \mathrm{ft}) \times 12 \mathrm{in.} / \mathrm{ft} \times[(5.452 / 2.566) /(0.9446 / 0.09354)]=$ $2.52 \mathrm{in} .=6.4 \mathrm{~cm}$.

This additional shielding is meant to accomnodate the uncertainty in extrapolating from the measurements, which were made at contact or at $30.48 \mathrm{~cm}$ (1 ft) of water shielding, to the application to basin water depths of 152.40 $\mathrm{cm}(5 \mathrm{ft})$ to $243.84 \mathrm{~cm}(8 \mathrm{ft})$ between the irradiated fuel storage canister and the water surface.

The $6.4 \mathrm{~cm}$ (2.52 in.), due to the ISOSHLD 4.0 and ISOSHLD-II dose rate ratio, is added to al1 ISOSHLD-II calculated minimum required water shielding thickness and is reflected in the tables of minimum water shield above the storage array. Experimental measurements were interpreted to support a closer correspondence with ISOSHLD 4.0 calculated dose rates than the ISOSHLD-II or ISO-PC 1.90 calculated dose rates. 
WHC-SD-NR-ER-105 Rev. 0

This page intentionaliy left blank. 


\subsection{CONCLUSIONS}

Consolidation of 105-KE Basin irradiated fuel into the 105-KW Basin will require double or triple stacking canisters closer to the surface of the basin water. The minimum water shielding thickness consistent with radiation shielding requirements, that is $2.0 \mathrm{mR} / \mathrm{h}$ for 7 imited access time and $0.20 \mathrm{mR} / \mathrm{h}$ for unlimited access time, were calculated.

Experimentally measured canister dose rates were consistently compared to ISOSHLD-II models of single canister geometry. The single canister model was converted into the canister storage location model. Irradiation was accommodated by determining the highest dose rate canister as a function of irradiation and decay time. The highest dose rate canister became the basis for the full-basin calculation. There is routine movement of basin canisters by lifting them up and out of their array position and moving across the array to another location. The active basin calculation logically combined the entire static basin array with the single canister dose rate by simple addition. Additional lifted and moving canisters were calculated and shown to be a minor concern. Basin water temperature was calculated and shown to be a minor concern. ISOSHLD-II calculated dose rates based on fission products only is reasonable because the contribution of ORIGEN2 calculated activation products and actinides and daughters was shown to be insignificant. The $6.4 \mathrm{~cm}$ (2.52 in.), due to the ISOSHLD 4.0 and ISOSHLD-II dose rate ratio, is added to all ISOSHLD-II calculated minimum required water shielding thickness and is reflected in the tables of minimum water shield above the storage array.

Table 23 shows the minimum required water shielding thickness for January 31,1995 , and three subsequent decay times.

Table 23. Calculated Minimum Water Shield Above Storage Array.

\begin{tabular}{|l|c|c|c|c|}
\cline { 2 - 5 } \multicolumn{1}{c|}{} & $\begin{array}{c}\text { Reference date } \\
+0 \text { days }\end{array}$ & $\begin{array}{c}\text { Reference } \\
+1,000 \text { days }\end{array}$ & $\begin{array}{c}\text { Reference } \\
+3,000 \text { days }\end{array}$ & $\begin{array}{c}\text { Reference } \\
+5,000 \text { days }\end{array}$ \\
\hline $\begin{array}{l}\text { Limited } \\
\text { Access time }\end{array}$ & $\begin{array}{r}210.4 \mathrm{~cm} \\
6 \mathrm{ft} 11 \mathrm{in} .\end{array}$ & $\begin{array}{c}209.4 \mathrm{ft} 11 \mathrm{in} . \\
6 \mathrm{ft}\end{array}$ & $\begin{array}{c}207.6 \mathrm{fm} \\
6 \mathrm{ft} \mathrm{in} .\end{array}$ & $\begin{array}{c}205.8 \mathrm{~cm} \\
\mathrm{ft} 10 \mathrm{in} .\end{array}$ \\
\hline $\begin{array}{l}\text { Unlimited } \\
\text { Access time }\end{array}$ & $\begin{array}{r}240.8 \mathrm{~cm} \\
7 \mathrm{ft} 11 \mathrm{in} .\end{array}$ & $\begin{array}{c}239.7 \mathrm{~cm} \\
7 \mathrm{ft} 11 \mathrm{in} .\end{array}$ & $\begin{array}{c}237.8 \mathrm{~cm} \\
7 \mathrm{ft} 10 \mathrm{in} .\end{array}$ & $\begin{array}{r}236.0 \mathrm{~cm} \\
7 \mathrm{ft} 9 \mathrm{in} .\end{array}$ \\
\hline
\end{tabular}

NOTES:

Calculated distance is from top of fuel storage array to water surface. Dose point is $152.4 \mathrm{~cm}$ (5 ft) air above water surface.

Situation: one canister $91.44 \mathrm{~cm}(3 \mathrm{ft})$ above storage array. Reference date is January $31,1995$.

'Limited access time (1 hour/day), calculated dose rate is $2 \mathrm{mR} / \mathrm{h}$.

'Unl imited access time, calculated dose rate is $0.2 \mathrm{mR} / \mathrm{h}$. 
The current operational level of $K$ basin pools is $490 \mathrm{~cm} \pm 15 \mathrm{~cm}(16.0 \pm$ $0.5 \mathrm{ft}$ ) measured from the bottom of the pool to the surface of the water. The Kaiser engineering study sketches ES-N040-S03 and ES-NO40-SO4 for Option B (Kaiser 1994) designed $227.01 \mathrm{~cm}$ ( $7 \mathrm{ft} 5 \%$ in.) for canisters stacked three high. This design would leave only $260.67 \pm 15.24 \mathrm{~cm}$ ( $8 \mathrm{ft} 6 \mathrm{H}$ in. $\pm 0.5 \mathrm{ft}$ ) of water shielding above the top canister lid.

At a minimum there would be $245.43 \mathrm{~cm}$ ( $8 \mathrm{ft}$ in.) of water shielding above the top canister lid when stacked three high. Since these ISOSHLD-II calculated water shield minimum required thicknesses are less than the minimum design water thickness, this proposed design, Option B, is acceptable according to the radiation shielding design requirements. The current operational limit of three canisters per storage bay out of storage and on hoists will not be affected.

The most limiting design for radiation shielding concerns is the one which requires the maximum vertical spacing between canister layers. Option A requires no spacing between canister layers while Option B requires $4.445 \mathrm{~cm}$ (13 in.) vertical spacing between canister layers. These shielding calculations showed that Option B is acceptable, and it is also true that all design vertical spacings less than $4.445 \mathrm{~cm}$ (1 $\frac{3}{2}$ in.) are also acceptable.

These ISOSHLD-II calculations for minimum required water shielding thickness are reasonable because they were compared to single canister experimental measurements and extended by stages to the active fuel storage basin desired configuration. Comparisons were made to other ISOSHLD versions and ISOSHLD 4.0, which more consistent7y reproduced the experimental measurements, was used for a conservative adjustment in bridging between the experimental measurements and the active basin dose rate calculation.

The ISOSHLD-II model has a small nonconservative effect due to neglecting some PVC pipe, detector structure, and about 1 in. of air shielding present in the experimental measurements but not replicated in the ISOSHLD-II models. The effect of this simplifying assumption is believed to be small and within the accuracy of the experimental measurements and is accommodated by scaling to ISOSHLD 4.0 calculated dose rates.

The ISOSHLD-II calculations for minimum required water shielding thickness are conservative because: (1) a lifted canister was considered as the normal basin configuration, (2) the reconstructed SCATS accountability database was used for fuel exposure, and this has been shown to be $16 \%$ higher than another accountability database that did not use fuel segregation data, (3) all irradiated fuel is assumed to be maximum length MKIV fuel and to be irradiated to the maximum exposure key in 105-KE Basin, 16.3330 wt\% ${ }^{240} \mathrm{Pu}$, (4) the maximum irradiated uranium is RIBD calculated to have approximately $10 \%$ more ${ }^{137} \mathrm{Cs}$ gamma source term than a similar ORIGEN2 irradiation calculation, (5) when minimum basin water level was assumed, there was no increase in the air distance to the grating dose rate point, (6) the moving canister dose rate was added to the static basin array dose rate without subtracting the contribution from the shielded canister below the suspended canister, and (7) comparison of ISOSHLD-II to other available ISOSHLD versions and acceptance of higher dose rate calculation of ISOSHLD 4.0 which used more recent dose buildup factors. 
The ISOSHLD-II calculations were performed considering the base case to be the active basin situation, that is that a canister or canisters are lifted $91.44 \mathrm{~cm}(3 \mathrm{ft})$ above the top of a three-high storage array which is assumed to be vertically spaced according to Kaiser's Option B $4.445 \mathrm{~cm}$ (1 $1 \frac{1}{4}$ in.) maximum spacing between layers. 
WHC-SD-NR-ER-105 Rev. 0

This page intentionally left blank. 


\subsection{REFERENCES}

Croff, A. C., 1980, A User's Manual for the ORIGEN2 Computer Code, ORNL/TM-7175, Oak Ridge National Laboratory, Oak Ridge, Tennessee.

DLC-129, 1993, "ANS643 ANS-6.4.3 Geometric Progression Gamma-Ray Buildup Factor Coefficients," Oak Ridge National Laboratory, Oak Ridge, Tennessee.

DOE, 1988, Requirements for Radiation Protection, DOE Order 5480.11, U.S. Department of Energy, Washington, D.C.

DOE, 1989, General Design Criteria, DOE Order 6430.1A, U.S. Department of Energy, Washington, D.C.

Drawing H-1-36935 sheets 1 and 2, "Irradiated Fuel Storage Canister," Iast updated April 18, 1980.

Drawings H-1-42793 sheets 1 and 2, "Fuel Encapsulation Program Storage Canister," Tast updated July 15, 1981.

Drawings H-1-46215 sheets 1 through 7, "Fuel Encapsulation MKII Canister Assembiy," dated March 14, 1985.

Enge1, R. L., J. Greenborg, and M. M. Hendrickson, 1966, ISOSHLD-A Computer Code for General Purpose Isotope Shielding Analysis, BNWL-236, Pacific Northwest Laboratory, Richland, Washington.

Hedengren, D. C., 1985, ORIGEN2 Predictions of N Reactor Fuel Fission Product Composition, WHC-SD-CP-TI-077, Westinghouse Hanford Company, Richl and, Washington.

Hedengren, D. C., 1986, ORIGEN2 Predictions of $N$ Reactor Cladding and Fuel Activation Product Composition, WHC-SD-CP-TI-094; Westinghouse Hanford Company, Richland, Washington.

Hedengren, D. C. and H. J. Goldberg, 1987, ORIGEN2 Predictions of N Reactor Fuel Actinide Composition, WHC-SD-CP-TI-105, Westinghouse Hanford Company, Richland, Washington.

Kaiser, 1994, Engineering Study: Spent Fuel Consolidation in the 105KW Fue 7 Storage Basin, Working Outl ine N040ES.TD.664, Issue B, April 1994, ICF Kaiser Hanford Company, Richland, Washington.

Mansius, C. A., 1969, A Revised Photon Probability Library for Use with ISOSHLD-III, BNWL-236. SUP. 2, Pacific Northwest Laboratory, Richland, Washington.

Schlosser, J. E., 1990; The Safeguards Control and Accountability Transactions System: SCATS, Program Documentation, WHC-SD-NR-CSWD-047, Rev. 0 , Westinghouse Hanford Company, Richland, Washington. 
Schlosser, J. E., 1992a, The AJAX Program, The Estimation of Isotopics of $N$ Reactor Unsegregated Irradiated Fuels, WHC-SD-NR-CSWD-048, Rev. 0 , Westinghouse Hanford Company, Richland, Washington.

Schlosser, J. E., 1992b, The FUELSEG Program, The Estimation of Isotopics of N Reactor Segregated Irradiated Fuels, WHC-SD-NR-CSWD-049, Rev. 0, Westinghouse Hanford Company, Richland, Washington.

Schmittroth, F. A., 1993, Software Certification Package for the ORIGEN2 Code, WHC-SD-NR-SWD-006, Rev. 1, Westinghouse Hanford Company, Richland, Washington.

WHC-CM-4-9, 1988, Radiological Design Safety, Quality Assurance and Security, Westinghouse Hanford Company, Richland, Washington.

Wittekind, W. D., 1984, PT-N-539 Calibration of N-Fuel Sort

Instrumentation Final Report, UNI-2362 A, United Nuclear Industries, Richland, Washington.

Wittekind, W. D., 1986, Isotopic Segregation Tables Calculated Adjustment of June 9, 1986 Using the Computer Code PTABLESEG2, UNI-4008, United Nuclear Industries, Richland, Washington.

Wittekind, W. D., 1988a, N Reactor Isotopic Production Tables Calculated Adjustment of March 24, 1987 Using the Computer Code AJAX PTABLE, WHC-00188, Westinghouse Hanford Company, Richland, Washington.

Wittekind, W. D., 1988b, Irradiated N Reactor Fuel Dose Rate Measurements and ISOSHLD Calculations, WHC-SP-0306, Westinghouse Hanford Company, Richland, Washington.

Wittekind, W.D., 1991, Irradiated N Reactor Fuel Consolidated Storage Shielding Calculations, WHC-SD-NR-ER-090, Westinghouse Hanford Company, Richl and, Washington.

Wittekind, W. D., 1994a, Consolidated Fuel Decay Heat Calculations, WHC-SD-NR-ANAL-014, Rev. 0, Westinghouse Hanford Company, Richl and, Washington.

Wittekind, W. D., 1994b, Software Certification Package for the ISOSHLD-II Code, WHC-SD-NR-SWD-019, Rev. O, Westinghouse Hanford Company, Richiand, Washington.

Wittekind, W. D., 1994c, Software Certification Package for the ORIGEN2 Code, WHC-SD-NR-SWD-006, Rev. 0, Westinghouse Hanford Company, Richl and, Washington. 
WHC-SD-NR-ER-105 Rev. 0

APPENDIX A

RECONSTRUCTED SCATS ACCOUNTABILITY DATABASE

A-1 
WHC-SD-NR-ER-105 Rev. 0

This page intentionally left blank.

A-2 


\section{RECONSTRUCTED SCATS ACCOUNTABILITY DATABASE}

Basin: "E" means 105-KE Basin, "W" means 105-KW Basin.

Key: A basin key denoted by the HAPO day number.

Decay Date: The reference date for isotopic composition calculation.

Material type: MKIA, MKIV, or Natural enrichment MKIV.

Single Pass Reactor (SPR) fuel is not well designated.

Pieces: May be assemblies, outers, or inners.

Pu: The quantity of plutonium in grams on the reference date.

$U$ : The quantity of uranium in kilograms on the reference date.

Wt\% ${ }^{240} \mathrm{Pu}$ : Calculated weight percent ${ }^{240} \mathrm{Pu}$ in plutonium on reference date.

This indicates the uranium exposure.

\begin{tabular}{|c|c|c|c|c|c|c|}
\hline $\begin{array}{cc}\text { asin } & \text { Key } \\
\text { E } & 9621 \\
E & 9621 \\
E & 10001 \\
E & 10201 \\
E & 10259 \\
E & 10259 \\
E & 10294 \\
E & 10294 \\
E & 10294 \\
E & 10350 \\
E & 10385 \\
E & 10385 \\
E & 10456 \\
E & 10456 \\
E & 10576 \\
E & 10602 \\
E & 10602 \\
E & 10602 \\
E & 10679 \\
E & 10679 \\
E & 10742 \\
E & 10742 \\
E & 10742 \\
E & 10764 \\
E & 10764 \\
E & 10770 \\
E & 10770 \\
E & 10832 \\
E & 10832 \\
E & 10832 \\
E & 10982 \\
E & 10982 \\
E & 11036 \\
E & 11036 \\
E & 11036 \\
E & 11109 \\
E & 11109 \\
E & 11183 \\
E & 11183 \\
E & 11183\end{array}$ & $\begin{array}{l}\text { Decay Date } \\
01 / 31 / 92 \\
01 / 31 / 92 \\
01 / 31 / 92 \\
01 / 31 / 92 \\
01 / 31 / 92 \\
01 / 31 / 92 \\
01 / 31 / 92 \\
01 / 31 / 92 \\
01 / 31 / 92 \\
01 / 31 / 92 \\
01 / 31 / 92 \\
01 / 31 / 92 \\
01 / 31 / 92 \\
01 / 31 / 92 \\
01 / 31 / 92 \\
01 / 31 / 92 \\
01 / 31 / 92 \\
01 / 31 / 92 \\
01 / 31 / 92 \\
01 / 31 / 92 \\
01 / 31 / 92 \\
01 / 31 / 92 \\
01 / 31 / 92 \\
01 / 31 / 92 \\
01 / 31 / 92 \\
01 / 31 / 92 \\
01 / 31 / 92 \\
01 / 31 / 92 \\
01 / 31 / 92 \\
01 / 31 / 92 \\
01 / 31 / 92 \\
01 / 31 / 92 \\
01 / 31 / 92 \\
01 / 31 / 92 \\
01 / 31 / 92 \\
01 / 31 / 92 \\
01 / 31 / 92 \\
01 / 31 / 92 \\
01 / 31 / 92 \\
01 / 31 / 92\end{array}$ & $\begin{array}{l}\text { type } \\
\text { MIV } \\
\text { NAT } \\
\text { MIV } \\
\text { MIV } \\
\text { MIV } \\
\text { MIV } \\
\text { MIV } \\
\text { MIV } \\
\text { MIV } \\
\text { MIV } \\
\text { MIV } \\
\text { MIV } \\
\text { MIV } \\
\text { MIV } \\
\text { MIV } \\
\text { MIV } \\
\text { MIV } \\
\text { MIV } \\
\text { MIV } \\
\text { MIV } \\
\text { MIV } \\
\text { MIV } \\
\text { MIV } \\
\text { MIV } \\
\text { NAT } \\
\text { MIV } \\
\text { MIV } \\
\text { MIV } \\
\text { MIV } \\
\text { MIV } \\
\text { MIV } \\
\text { MIV } \\
\text { MIV } \\
\text { MIV } \\
\text { MIV } \\
\text { MIV } \\
\text { MIV } \\
\text { MIV } \\
\text { MIV } \\
\text { MIV }\end{array}$ & $\begin{array}{c}\text { Pieces } \\
75 \\
63 \\
17 \\
262 \\
48 \\
1792 \\
3024 \\
192 \\
84 \\
48 \\
2912 \\
167 \\
2072 \\
270 \\
336 \\
624 \\
924 \\
756 \\
1064 \\
1233 \\
524 \\
784 \\
532 \\
184 \\
4 \\
860 \\
840 \\
2296 \\
744 \\
1596 \\
1328 \\
896 \\
224 \\
364 \\
552 \\
1380 \\
840 \\
1843 \\
1456 \\
1092\end{array}$ & $\begin{array}{r}\text { Pu }(g) \\
151.17 \\
142.96 \\
171.16 \\
4212.43 \\
891.17 \\
35922.63 \\
62550.94 \\
3551.79 \\
2150.06 \\
857.25 \\
66265.65 \\
3465.38 \\
44066.31 \\
6540.87 \\
7472.42 \\
19346.21 \\
25845.47 \\
16699.27 \\
22362.47 \\
38251.36 \\
17052.21 \\
21300.65 \\
10970.10 \\
0.00 \\
0.00 \\
26640.76 \\
17788.41 \\
63969.53 \\
23853.04 \\
33869.72 \\
43368.74 \\
18898.08 \\
6386.66 \\
7392.04 \\
17528.96 \\
43951.70 \\
17668.02 \\
59601.27 \\
41238.88 \\
23550.56\end{array}$ & $\begin{array}{r}U(\mathrm{~kg}) \\
182.53 \\
218.71 \\
139.20 \\
2652.11 \\
534.95 \\
19809.02 \\
34667.16 \\
2180.11 \\
966.82 \\
528.51 \\
33857.17 \\
1922.67 \\
23303.78 \\
3079.31 \\
3918.27 \\
7161.09 \\
10733.45 \\
8768.29 \\
11663.89 \\
14240.30 \\
6093.17 \\
8775.18 \\
5656.47 \\
1972.00 \\
46.75 \\
9831.86 \\
9353.97 \\
26344.62 \\
8434.92 \\
17902.13 \\
15338.47 \\
9815.89 \\
2595.92 \\
4009.62 \\
6369.28 \\
15877.67 \\
9329.96 \\
21352.39 \\
16792.40 \\
12623.76\end{array}$ & $\begin{array}{r}\text { Wt }{ }^{240} \mathrm{Pu} \\
6.0059 \% \\
5.4636 \% \\
9.7457 \% \\
8.9414 \% \\
9.5026 \% \\
10.2448 \% \\
10.1920 \% \\
9.1658 \% \\
12.4467 \% \\
9.1004 \% \\
11.0264 \% \\
10.1276 \% \\
10.8237 \% \\
12.1389 \% \\
10.8658 \% \\
15.1278 \% \\
13.5238 \% \\
10.8991 \% \\
10.9016 \% \\
15.0223 \% \\
15.5346 \% \\
13.5581 \% \\
10.9779 \% \\
0.0000 \% \\
0.0000 \% \\
15.0849 \% \\
10.8370 \% \\
13.5879 \% \\
15.7130 \% \\
10.7842 \% \\
15.6842 \% \\
10.9202 \% \\
13.7577 \% \\
10.5633 \% \\
15.2450 \% \\
15.3470 \% \\
10.7568 \% \\
15.4768 \% \\
13.7052 \% \\
10.6101 \%\end{array}$ \\
\hline
\end{tabular}


WHC-SD-NR-ER-105 Rev. 0

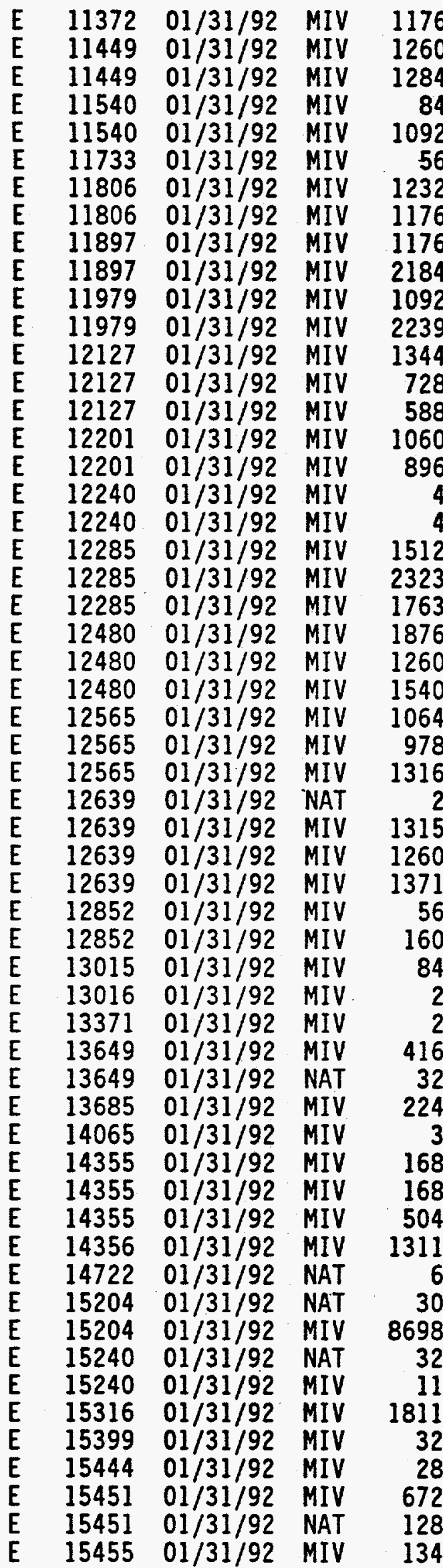

\begin{tabular}{|c|c|c|c|}
\hline 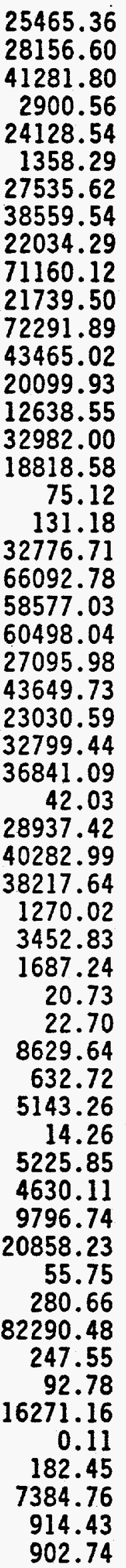 & $\begin{array}{r}13402.92 \\
14469.78 \\
14755.24 \\
977.12 \\
12526.83 \\
644.30 \\
14244.51 \\
13660.31 \\
11718.21 \\
24995.64 \\
11622.88 \\
25342.30 \\
15461.22 \\
8265.23 \\
6749.34 \\
12083.48 \\
10062.64 \\
46.72 \\
46.55 \\
17301.54 \\
26878.65 \\
20275.91 \\
21695.37 \\
14539.72 \\
17814.03 \\
12303.84 \\
11320.30 \\
15160.13 \\
23.37 \\
15276.44 \\
14494.72 \\
15883.50 \\
653.05 \\
1867.50 \\
868.93 \\
21.98 \\
3117.52 \\
308.42 \\
6928.84 \\
1496.21 \\
1494.66\end{array}$ & 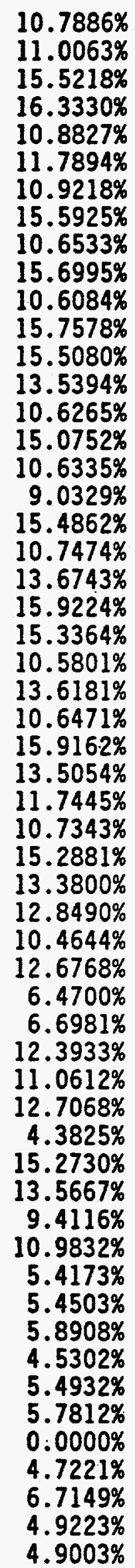 & 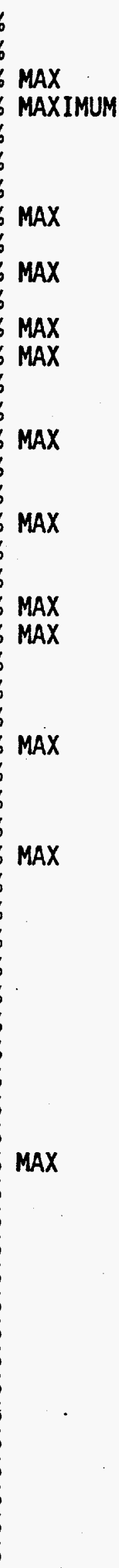 \\
\hline
\end{tabular}


WHC-SD-NR-ER-105 ReV. 0

$\begin{array}{ll}E & 15457 \\ E & 15457 \\ E & 15458 \\ E & 15458 \\ E & 15460 \\ E & 15460 \\ E & 15461 \\ W & 9621 \\ W & 9964 \\ W & 9964 \\ W & 9993 \\ W & 10001 \\ W & 10201 \\ W & 10259 \\ W & 10294 \\ W & 10350 \\ W & 10385 \\ W & 10456 \\ W & 10602 \\ W & 10679 \\ W & 10742 \\ W & 10764 \\ W & 10764 \\ W & 10770 \\ W & 10832 \\ W & 10982 \\ W & 11036 \\ W & 11109 \\ W & 11183 \\ W & 11372 \\ W & 11449 \\ W & 11540 \\ W & 11540 \\ W & 11806 \\ W & 11897 \\ W & 13016 \\ W & 13017 \\ W & 13371 \\ W & 13372 \\ W & 12127 \\ W & 12201 \\ W & 12285 \\ W & 12480 \\ W & 12565 \\ W & 12565 \\ W & 12639 \\ W & 12823 \\ W & 12852 \\ W & 12852 \\ W & 12852 \\ W & 12942 \\ W & 13015 \\ W & 13015 \\ W & \end{array}$

$01 / 31 / 92$

$01 / 31 / 92$

$01 / 31 / 92$

$01 / 31 / 92$

$01 / 31 / 92$

$01 / 31 / 92$

$01 / 31 / 92$

$01 / 31 / 92$

$01 / 31 / 92$

$01 / 31 / 92$

$01 / 31 / 92$

$01 / 31 / 92$

$01 / 31 / 92$

$01 / 31 / 92$

$01 / 31 / 92$

$01 / 31 / 92$

$01 / 31 / 92$

$01 / 31 / 92$

$01 / 31 / 92$

$01 / 31 / 92$

$01 / 31 / 92$

$01 / 31 / 92$

$01 / 31 / 92$

$01 / 31 / 92$

$01 / 31 / 92$

$01 / 31 / 92$

$01 / 31 / 92$

$01 / 31 / 92$

$01 / 31 / 92$

$01 / 31 / 92$

$01 / 31 / 92$

$01 / 31 / 92$

$01 / 31 / 92$

$01 / 31 / 92$

$01 / 31 / 92$

$01 / 31 / 92$

$01 / 31 / 92$

$01 / 31 / 92$

$01 / 31 / 92$

$01 / 31 / 92$

$01 / 31 / 92$

$01 / 31 / 92$

$01 / 31 / 92$

$01 / 31 / 92$

$01 / 31 / 92$

$01 / 31 / 92$

$01 / 31 / 92$

$01 / 31 / 92$

$01 / 31 / 92$

$01 / 31 / 92$

$01 / 31 / 92$

$01 / 31 / 92$

$01 / 31 / 92$

$01 / 31 / 92$

$01 / 31 / 92$

$01 / 31 / 92$.
NAT

MIV

MIV 11858

NAT 32

NAT

MIV 1440

MIV 1088

MIA 47

MIV

MIA

MIA

MIV

MIA

MIA

MIA

MIA $\quad 1988$

MIA 1005

MIA 2016

MIA 1763

MIA 1428

MIA

MIA

MIV

MIA

MIA

MIA
MIA

MIA

MIA

MIA

MIA

MIA

MIA

MIA

MIA

MIA

MIA

MIA

MIA

MIV

MIA

MIA

MIA

MIV

MIV

MIA

MIA

MIV 4532

MIV 3972

NAT 32

MIA 2532

MIV 2352

MIA $\quad 616$

MIV 1814

$\begin{array}{r}12.42 \\ 198.53 \\ 72685.68 \\ 181.59 \\ 971.11 \\ 9725.90 \\ 2473.19 \\ 102.28 \\ 55.58 \\ 555.04 \\ 13965.36 \\ 1109.66 \\ 20336.43 \\ 4937.24 \\ 30055.01 \\ 26636.21 \\ 13762.23 \\ 29702.50 \\ 25818.77 \\ 21350.66 \\ 13598.03 \\ 0.00 \\ 0.00 \\ 17199.87 \\ 34502.52 \\ 37715.77 \\ 16486.73 \\ 32938.33 \\ 21976.99 \\ 43236.77 \\ 42676.28 \\ 32887.93 \\ 26426.73 \\ 44145.50 \\ 45426.92 \\ 57905.28 \\ 35875.68 \\ 52809.87 \\ 41671.83 \\ 42929.13 \\ 19815.17 \\ 55365.85 \\ 49347.52 \\ 16147.30 \\ 130130.61 \\ 12144.08 \\ 28640.58 \\ 42506.49 \\ 672.32 \\ 95297.86 \\ 85046.74 \\ 44494.20 \\ 10448.50 \\ 36795.31 \\ \hline\end{array}$

131

46.79

290.17

131914.03

374.15

2947.30

14924.34

12727.53

105.50

74.85

317.85

8448.59

902.46

14095.26

2959.75

19118.45

15780.23

8233.86

16539.92

14500.72

11465.97

6643.22

16.57

303.86

8167.46

16740.73

17205.67

7596.66

15071.41

10295.43

19925.91

19942.12

11563.39

12460.51

19945.00

19665.22

25316.56

15749.02

25068.61

19722.25

19408.82

6833.33

25194.95

23574.21

7833.94

66913.67

4188.92

13705.47

20393.64

373.94

52443.23

43798.91

373.94

20602.28

26850.17

4984.96

19284.08
$1.7028 \%$

4.3223\%

$4.2286 \%$

$3.4295 \%$

$2.8092 \%$

$4.2624 \%$

$1.5482 \%$

$6.1508 \%$

$6.0137 \%$

$10.6892 \%$

$10.1176 \%$

$9.7457 \%$

$9.0208 \%$

$10.2067 \%$

9.6313\%

$10.3334 \%$

$10.2122 \%$

$11.0718 \%$

$10.8561 \%$

$11.4572 \%$

$12.4119 \%$

$0.0000 \%$

$0.0000 \%$

$12.7531 \%$

$12.5178 \%$

$13.2388 \%$

$13.1223 \%$

$13.2117 \%$

$12.9001 \%$

$13.2644 \%$

$12.9521 \%$

15.7326\% MAX

$12.8148 \%$

$13.3331 \%$

$13.8381 \%$

$13.7351 \%$

$13.6626 \%$

$12.7526 \%$

$12.7426 \%$

$13.2626 \%$

$15.9252 \%$ MAX

$13.1894 \%$

$12.6170 \%$

$12.6872 \%$

$12.8490 \%$

15.8559\% MAX

$12.5752 \%$

$12.6096 \%$

$11.7253 \%$

$12.2845 \%$

$12.6768 \%$

$11.7550 \%$

$12.8199 \%$

$11.0057 \%$

$12.5326 \%$

$12.3706 \%$ 
WHC-SD-NR-ER-105 Rev. .0

$\begin{array}{lrllrrrr}W & 13524 & 01 / 31 / 92 & \text { MIV } & 3416 & 72431.45 & 37578.85 & 12.5459 \% \\ W & 13525 & 01 / 31 / 92 & \text { MIA } & 2184 & 38186.77 & 17551.51 & 13.0218 \% \\ W & 13648 & 01 / 31 / 92 & \text { MIA } & 4 & 38.72 & 33.11 & 7.1663 \% \\ W & 13650 & 01 / 31 / 92 & \text { MIA } & 2100 & 35962.19 & 16546.69 & 12.9600 \% \\ W & 13686 & 01 / 31 / 92 & \text { MIA } & 2166 & 35800.06 & 17856.03 & 12.0334 \% \\ W & 13724 & 01 / 31 / 92 & \text { MIA } & 2 & 14.12 & 15.51 & 5.9186 \% \\ W & 13858 & 01 / 31 / 92 & \text { NAT } & 32 & 669.92 & 373.95 & 11.6340 \% \\ W & 13858 & 01 / 31 / 92 & \text { MIV } & 4633 & 92534.75 & 52407.41 & 11.5760 \% \\ W & 13859 & 01 / 31 / 92 & \text { MIA } & 3616 & 58312.78 & 29593.35 & 11.9141 \% \\ W & 14055 & 01 / 31 / 92 & \text { MIV } & 28 & 304.23 & 326.33 & 6.3913 \% \\ W & 14065 & 01 / 31 / 92 & \text { MIV } & 12 & 76.56 & 120.19 & 4.3825 \% \\ W & 14448 & 01 / 31 / 92 & \text { MIV } & 1 & 13.05 & 14.95 & 6.0803 \% \\ W & 14883 & 01 / 31 / 92 & \text { MIV } & 2 & 19.84 & 23.39 & 5.7909 \% \\ W & 15204 & 01 / 31 / 92 & \text { MIV } & 1 & 13.49 & 15.91 & 5.8908 \% \\ W & 15244 & 01 / 31 / 92 & \text { MIA } & 45 & 528.93 & 352.79 & 10.4053 \% \\ W & 15244 & 01 / 31 / 92 & \text { MIV } & 1 & 8.64 & 7.03 & 9.7456 \% \\ W & 15347 & 01 / 31 / 92 & \text { MIA } & 19 & 216.43 & 144.36 & 10.4053 \% \\ W & 15445 & 01 / 31 / 92 & \text { MIA } & 242 & 1522.98 & 1965.91 & 5.2503 \% \\ W & 15448 & 01 / 31 / 92 & \text { MIA } & 5 & 48.85 & 32.58 & 10.4053 \% \\ W & 15451 & 01 / 31 / 92 & \text { MIA } & 56 & 386.34 & 465.45 & 5.2558 \% \\ W & 15457 & 01 / 31 / 92 & \text { MIA } & 4 & 15.44 & 33.28 & 2.8178 \% \\ W & 15459 & 01 / 31 / 92 & \text { MIA } & 4150 & 20403.56 & 33920.63 & 4.0322 \% \\ W & 15460 & 01 / 31 / 92 & \text { MIA } & 252 & 1042.67 & 2096.24 & 3.3043 \% \\ W & 15555 & 01 / 31 / 92 & \text { MIA } & 2 & 28.89 & 19.27 & 10.4053 \% \\ W & & & & & \end{array}$

Totals (Average $\left.W t \%{ }^{240} \mathrm{Pu}\right) \quad 207496 \quad 4013818.51 \quad 2098362.14 \quad 12.5267 \%$ 
WHC-SD-NR-ER-105 Rev. 0

APPENDIX B

DOSE RATE MEASUREMENT CANISTERS

WERE STAINLESS STEEL

B-1 
WHC-SD-NR-ER-105 Rev. 0

This page intentionally left blank. 
WHC-SD-NR-ER-105 Rev. 0

[77] From: Karen R Morris at -WHC146 7/1/94 1:36PM (745 bytes: 16 in) To: Warren D Wittekind at -WHC71

Receipt Requested

cc: Karen R Morris, Lorie L Blehm

Subject: CANISTER INFORMATION K AREA

Warren;

This is the information that I could find for you.

Canister locations 5613,6806, 0804, 1205, 0669, and 3575 are a11 MKII canisters. This makes them stainiess stee? canisters. The other two canisters 2114 and 2106 , I could not get a determination if they are either were stainless or a) uminum.

Thanks

Karen Morris

Specialist, NMC

3-1565 
WHC-SD-NR-ER-105 Rev. 0

This page intentionally left blank. 
WHC-SD-NR-ER-105 Rev. 0

APPENDIX C

REPRESENTATIVE ISOSHLD-II INPUT FILES

C-1 
WHC-SD-NR-ER-105 Rev. 0

This page intentionally left blank. 
WHC-SD-NR-ER-105 Rev. 0

ISOSHLD-II Input for Half Canister Model 5TA, 6 wt\% ${ }^{240} \mathrm{Pu}$

1 FIVE REGION TOP SHIELDING, DECAY COMPARISONS

SEVEN ELEMENT IRRADIATION

$1.84625 \quad 112.00$

0.1164

360.0

0.90

$\begin{array}{llll}4.32 E+7 & 8.64 E+7 & 2.59 E+8 & 4.32 E+8\end{array}$

HALF CANISTER, TOP - MODEL \#5TA - 1/4 FOOT

SINPUT

NEXT $=1$,

IGEOM $=9$, NSHLD $=5, J B U F=5, \operatorname{ISPEC}=3, \operatorname{GROUP}(5)=1$. ,

$T(1)=65.3288, T(2)=0.4826, T(3)=0.5588, T(4)=1.27, T(5)=7.62$,

$X=227.6602, S L T H=10.254$, NTHETA $=11, N P S I=11, D E L R=0.400$,

SEND

URANUM 15

18.63

0.0

0.0

6.55

ZIRC 11

0.0

0.0

0.0

0.0

0.0

0.0

0.0

0.0

0.00129

0.0

0.0

$1 / 2$ FOOT

0.0

0.0

$\begin{array}{ll}\text { IRON } & 9 \\ \text { HATER } & 1\end{array}$

HALF CANISTER, TOP - MODEL \#5TA -

\$INPUT

NEXT $=4$,

$T(5)=15.24, X=235.2802$,

SEND

HALF CANISTER, TOP - MODEL \#5TA - 1 FOOT $\$$ INPUT

NEXT $=4$,

$T(5)=30.48, X=250.5202$,

SEND

HALF CANISTER, TOP - MODEL \#5TA -

2 FEET

\$INPUT

NEXT $=4$,

$T(5)=60.96, X=281.0002$,

SEND

HALF CANISTER, TOP - MODEL \#5TA -

3 FEET

\$INPUT

NEXT $=4$,

$T(5)=91.44, X=311.4802$;

SEND

HALF CANISTER, TOP - MODEL \#5TA -

4 FEET

\$INPUT

NEXT $=4$,

$T(5)=121.92, X=341.9602$,

SEND

HALF CANISTER, TOP - MODEL \#5TA - 5 FEET

\$INPUT

NEXT $=4$,

$T(5)=152.40, X=372.4402$,

SEND

HALF CANISTER, TOP - MODEL \#5TA -

\$INPUT

NEXT $=4$,

$T(5)=182.88, X=402.9202$,

SEND

HALF CANISTER, TOP - MODEL \#5TA \$INPUT

NEXT $=4$,

6 FEET

7 FEET 
$T(5)=213.36, X=433.4002$,

SEND

HALF CANISTER, TOP - MODEL \#5TA - 8 FEET

\$INPUT

NEXT $=4$,

$T(5)=243.84, X=463.8802$,

SEND

HALF CANISTER, TOP - MODEL \#5TA - 9 FEET

\$INPUT

NEXT $=4$,

$T(5)=274.32, X=494.3602$,

\$END

HALF CANISTER, TOP - MODEL \#5TA - 10 FEET

\$INPUT

NEXT $=4$,

$T(5)=304.80, X=524.8402$,

SEND

HALF CANISTER, TOP - 3 IN H20, 4 FEET AIR

\$INPUT

NEXT $=4$,

$T(5)=7.62, X=197.1802$,

\$END

HALF CANISTER, TOP - 3 IN H2O, 3 FEET AIR

$\$$ INPUT

NEXT $=4$,

$T(5)=7.62, X=166.7002$,

SEND

HALF CANISTER, TOP - 3 IN H20, 2 FEET AIR

$\$$ INPUT

NEXT $=4$,

$T(5)=7.62, X=136.2202$,

SEND

HALF CANISTER, TOP - 3 IN H2O, 1 FEET AIR

\$INPUT

NEXT $=4$,

$T(5)=7.62, X=105.7402$,

SEND

HALF CANISTER, TOP - 3 IN H2O, O FEET AIR

SINPUT

NEXT $=4$,

$T(5)=7.62, X=75.2602$,

\$END

HALF CANISTER, TOP - 2 IN H20, O FEET AIR

\$INPUT

NEXT $=4$,

$T(5)=5.08, X=72.7202$,

SEND

HALF CANISTER, TOP - 1 IN H20, O FEET AIR \$INPUT

NEXT $=4$,

$T(5)=2.54, X=70.1802$,

SEND

END OF CASE

\$INPUT

NEXT $=6$,

\$END 
WHC-SD-NR-ER-105 ReV. 0

ISOSHLD-II Input for Half Canister Model 6TB, 16 wt\% ${ }^{240} \mathrm{Pu}$

116 WT. PCT. PU-240, DECAY COMPARISON

SEVEN ELEMENT IRRADIATION 0.90

$\begin{array}{llllll}1.84625 & 406.00 & 0.4221 & 360.0 & 0.10 & 0\end{array}$

4.55E+8 5.41E+8 7.14E+8 8.87E+8

HALF CANISTER LOCATION, TOP - MODEL \#6TB(16) - $1 / 4$ FOOT \$INPUT

NEXT $=1$,

IGEOM $=10, N S H L D=5, J B U F=5, I S P E C=3, \operatorname{GROUP}(5)=1 ., Y=31.75$,

$T(1)=65.3288, T(2)=0.4826, T(3)=0.5588, T(4)=1.27, T(5)=7.62$,

$X=227.6602, S L T H=26.670$, NTHETA=11, NPSI $=11$, $D E L R=0.400$,

SEND

URANUM 15

ZIRC 11

18.63

0.0

0.0

6.55

AIR 3

0.0

0.0

0.0

0.0

0.0

0.0

0.0

IRON 9

0.0

0.00129

0.0

0.0

0.0

0.0

1 WATER 1

HALF CANISTER

SINPUT

NEXT $=4$,

$T(5)=15.24, X=235.2802$,

SEND

HALF CANISTER LOCATION, TOP - MODEL \#6TB(16) - 1 FOOT

\$INPUT

NEXT $=4$,

$T(5)=30.48, X=250.5202$,

SEND

HALF CANISTER LOCATION, TOP - MODEL \#6TB(16) - 2 FEET \$INPUT

NEXT $=4$,

$T(5)=60.96, X=281.0002$,

SEND

HALF CANISTER LOCATION, TOP - MODEL \#6TB(16) -

3 FEET

\$INPUT

NEXT $=4$,

$T(5)=91.44, X=311.4802$,

SEND

HALF CANISTER LOCATION, TOP - MODEL \#6TB(16) - 4 FEET

\$INPUT

NEXT $=4$,

$T(5)=121.92, X=341.9602$,

SEND

HALF CANISTER LOCATION, TOP - MODEL \#6TB(16) - 5 FEET \$INPUT

NEXT $=4$,

$T(5)=152.40, X=372.4402$,

SEND

HALF CANISTER LOCATION, TOP - MODEL \#6TB(16) - 6 FEET

SINPUT

NEXT $=4$,

$T(5)=182.88, X=402.9202$,

SEND

HALF CANISTER LOCATION, TOP - MODEL \#6TB(16) - 7 FEET \$INPUT

NEXT $=4$, 
$T(5)=213.36, X=433.4002$,

SEND

HALF CANISTER LOCATION, TOP - MODEL \#6TB(16) - 8 FEET

SINPUT

NEXT $=4$,

$T(5)=243.84, X=463.8802$,

SEND

HALF CANISTER LOCATION, TOP - MODEL \#6TB(16) - 9 FEET

\$INPUT

NEXT $=4$,

$T(5)=274.32, X=494.3602$,

SEND

HALF CANISTER LOCATION, TOP - MODEL \#6TB(16) - 10 FEET

SINPUT

NEXT $=4$,

$T(5)=304.80, X=524.8402$,

\$END

HALF CANISTER LOCATION, TOP - 3 IN H2O, 4 FEET AIR

\$INPUT

NEXT $=4$,

$T(5)=7.62, X=197.1802$,

\$END

HALF CANISTER LOCATION, TOP - 3 IN H2O, 3 FEET AIR SINPUT

NEXT $=4$,

$T(5)=7.62, X=166.7002$,

SEND

HALF CANISTER LOCATION, TOP - 3 IN H2O, 2 FEET AIR

\$INPUT

NEXT $=4$,

$T(5)=7.62, X=136.2202$,

SEND

HALF CANISTER LOCATION, TOP - 3 IN H2O, I FEET AIR \$INPUT

NEXT $=4$,

$T(5)=7.62, X=105.7402$,

SEND

HALF CANISTER LOCATION, TOP - 3 IN H2O, O FEET AIR \$INPUT

NEXT $=4$,

$T(5)=7.62, X=75.2602$,

SEND

HALF CANISTER LOCATION, TOP - 2 IN H2O, O FEET AIR

\$INPUT

NEXT $=4$,

$T(5)=5.08, X=72.7202$,

SEND

HALF CANISTER LOCATION, TOP - 1 IN H2O, 0 FEET AIR \$INPUT

NEXT $=4$,

$T(5)=2.54, X=70.1802$,

SEND

END OF CASE

\$INPUT

NEXT $=6$,

SEND 
WHC-SD-NR-ER-105 ReV. 0

ISOSHLD-II Input for Single Canister Model Bl, 16 wt\% ${ }^{240} \mathrm{Pu}$

1 BUILD UP TO FULL 1800 CANISTER BASIN

ONE CANISTER IRRADIATION

0.90

3.69250

406.00

0.4221

360.0

$0.10 \quad 0$

4.55E+8 5.41E+8 7.14E+8 8.87E+8

ONE CANISTER LOCATION, TOP - MODEL BI - 1/4 FOOT

SINPUT

NEXT $=1$,

IGEOM $=10, N S H L D=5, J B U F=5, I S P E C=3, \operatorname{GROUP}(5)=1 ., Y=31.75$,

$T(1)=65.3288, T(2)=0.4826, T(3)=0.5588, T(4)=1.27, T(5)=7.62$, $X=227.6602, S L T H=53.34, N T H E T A=22, N P S I=11, D E L R=0.400$,

SEND

URANUM 15

18.63

ZIRC 11

0.0

AIR 3

0.0

0.0

0.0

0.0

0.0

IRON 9

0.0

0.55

0.0

0.00129

0.0

0.0

0.0

0.0

0.0

0.0

0.0

0.0

1 WATER 1

ONE CANISTER LOCATION, TOP - MODEL BI -

8.030

0.0

0.0

\$INPUT

NEXT $=4$,

$T(5)=15.24, X=235.2802$,

SEND

ONE CANISTER LOCATION, TOP - MODEL BI - 1 FOOT

\$INPUT

NEXT $=4$,

$T(5)=30.48, X=250.5202$,

\section{SEND}

ONE CANISTER LOCATION, TOP - MODEL BI -

2 FEET

\$INPUT

NEXT $=4$,

$T(5)=60.96, X=281.0002$,

SEND

ONE CANISTER LOCATION, TOP - MODEL BI - 3 FEET

\$INPUT

NEXT $=4$,

$T(5)=91.44, X=311.4802$,

SEND

ONE CANISTER LOCATION, TOP - MODEL BI \$INPUT

NEXT $=4$,

$T(5)=121.92, X=341.9602$,

SEND

ONE CANISTER LOCATION, TOP - MODEL BI -

5 FEET

\$INPUT

NEXT $=4$,

$T(5)=152.40, X=372.4402$,

SEND

ONE CANISTER LOCATION, TOP - MOOEL BI -

4 FEET \$INPUT

NEXT $=4$,

$T(5)=182.88, X=402.9202$,

SEND

ONE CANISTER LOCATION, TOP - MODEL BI \$INPUT

NEXT=4, 
$T(5)=213.36, X=433.4002$,

SEND

ONE CANISTER LOCATION, TOP - MODEL BI - 8 FEET \$INPUT

NEXT $=4$,

$T(5)=243.84, X=463.8802$,

SEND

ONE CANISTER LOCATION, TOP - MODEL BI - 9 FEET.

\$INPUT

NEXT $=4$,

$T(5)=274.32, X=494.3602$,

\$END

\$INPUT

ONE CANISTER LOCATION, TOP - MODEL BI - 10 FEET

NEXT $=4$,

$T(5)=304.80, X=524.8402$,

SEND

ONE CANISTER LOCATION, TOP - MODEL BI - 11 FEET \$INPUT

NEXT $=4$,

$T(5)=335.28, X=555.3202$,

\$END

ONE CANISTER LOCATION, TOP - MODEL B1 - 12 FEET \$INPUT

NEXT $=4$,

$T(5)=365.76, X=585.8002$,

\$END

ONE CANISTER LOCATION, TOP - MODEL BI - 13 FEET \$INPUT.

NEXT $=4$,

$T(5)=396.24, X=616.2802$,

SEND

ONE CANISTER LOCATION, TOP - MODEL B1 - 14 FEET

\$INPUT

NEXT $=4$,

$T(5)=426.72, X=646.7602$,

SEND

ONE CANISTER LOCATION, TOP - MODEL BI - 15 FEET \$INPUT

NEXT $=4$,

$T(5)=457.20, X=677.2402$,

SEND

ONE CANISTER LOCATION, TOP - MODEL BI - . 16 FEET

\$INPUT

NEXT $=4$,

$T(5)=487.68, X=707.7202$,

SEND

END OF CASE

SINPUT

NEXT $=6$,

SEND 
WHC-SD-NR-ER-105 Rev. 0

ISOSHLD-II Input for Static Basin Model B1800, 16 wt\% ${ }^{240} \mathrm{Pu}$

1 BUILD UP TO FULL 1800 CANISTER BASIN

1800 CANISTER IRRADIATION 0.90

$\begin{array}{llllll}6646.50 & 406.00 & 0.4221 & 360.0 & 0.10 & 0\end{array}$

$4.55 E+8 \quad 5.41 E+8 \quad 7.14 E+8 \quad 8.87 E+8$

1800 CANISTER LOCATIONS, TOP - MODEL B1800 - $1 / 4$ FOOT

SINPUT

NEXT $=1$,

IGEOM $=10, N S H L D=5, J B U F=5, \operatorname{ISPEC}=3, \operatorname{GROUP}(5)=1 ., Y=1905.00$,

$T(1)=65.3288, T(2)=0.4826, T(3)=0.5588, T(4)=1.27, T(5)=7.62$,

$X=227.6602, S L T H=1600.20$, NTHETA $=44$, NPSI $=22, D E L R=0.400$,

\$END

URANUM 15

ZIRC 11

18.63

0.0

0.0

0.0

0.0

0.0

AIR 3

0.0

6.55

0.0

0.0

0.0 IRON 9

0.0

0.0

0.00129

0.0

0.0

1 WATER 1

0.0

0.0

8.030

0.0

1800 CANISTER LOCATIONS, TOP - MODEL B1800 - $1 / 2$ FOOT

\$INPUT

NEXT $=4$,

$T(5)=15.24, X=235.2802$,

SEND

1800 CANISTER LOCATIONS, TOP - MODEL B1800 - 1 FOOT

\$INPUT

NEXT $=4$,

$T(5)=30.48, X=250.5202$,

\$END

1800 CANISTER LOCATIONS, TOP - MODEL B1800 -

$\$$ INPUT

NEXT $=4$,

$T(5)=60.96, X=281.0002$,

\$END

1800 CANISTER LOCATIONS, TOP - MODEL B1800 -

3 FEET

\$INPUT

NEXT $=4$,

$T(5)=91.44, X=311.4802$,

SEND

1800 CANISTER LOCATIONS, TOP - MODEL B1800 -

\$INPUT

NEXT $=4$,

$T(5)=121.92, X=341.9602$,

SEND

1800 CANISTER LOCATIONS, TOP - MODEL B1800 -

2 FEET

$\$$ INPUT

NEXT $=4$,

$T(5)=152.40, X=372.4402$,

SEND

1800 CANISTER LOCATIONS, TOP - MODEL B1800 -

SINPUT

NEXT $=4$,

$T(5)=182.88, X=402.9202$,

SEND

1800 CANISTER LOCATIONS, TOP - MODEL B1800 -

\$INPUT

NEXT $=4$,

4 FEET

5 FEET

6 FEET

7 FEET 
$T(5)=213.36, X=433.4002$,

SEND

1800 CANISTER LOCATIONS, TOP - MODEL B1800 -

8 FEET

\$INPUT

NEXT $=4$,

$T(5)=243.84, X=463.8802$,

\$END

1800 CANISTER LOCATIONS, TOP - MODEL B1800 -

9 FEET

$\$$ INPUT

NEXT $=4$,

$T(5)=274.32, X=494.3602$,

SEND

1800 CANISTER LOCATIONS, TOP - MODEL B1800 -

$\$$ \$NPUT

NEXT $=4$,

$T(5)=304.80, X=524.8402$,

SEND

1800 CANISTER LOCATIONS, TOP - MODEL B1800 -

11 FEET

\$INPUT

NEXT $=4$,

$T(5)=335.28, X=555.3202$,

\$END

1800 CANISTER LOCATIONS, TOP - MODEL B1800 \$INPUT

NEXT $=4$,

$T(5)=365.76, X=585.8002$,

SEND

1800 CANISTER LOCATIONS, TOP - MODEL B1800 -

$\$$ \$NPUT

NEXT $=4$,

$T(5)=396.24, X=616.2802$,

\$END

1800 CANISTER LOCATIONS, TOP - MODEL B1800 -

\$INPUT

NEXT $=4$,

$T(5)=426.72, X=646.7602$,

SEND

1800 CANISTER LOCATIONS, TOP - MODEL B1800 -

\$INPUT

NEXT $=4$,

$T(5)=457.20, X=677.2402$,

SEND

1800 CANISTER LOCATIONS, TOP - MODEL B1800 -

\$INPUT

NEXT $=4$,

$T(5)=487.68, X=707.7202$,

SEND

END OF CASE

SINPUT

NEXT $=6$,

SEND 
WHC-SD-NR-ER-105 ReV. 0

\section{APPENDIX D}

REPRESENTATIVE ISOSHLD-II OUTPUT

(Output is from Full-Basin Model B1800.) 
WHC-SD-NR-ER-105 Rev. 0

This page intentionally left blank. 


\section{ISOSHLD-II Partial Output for 1800 Canisters Model B1800}

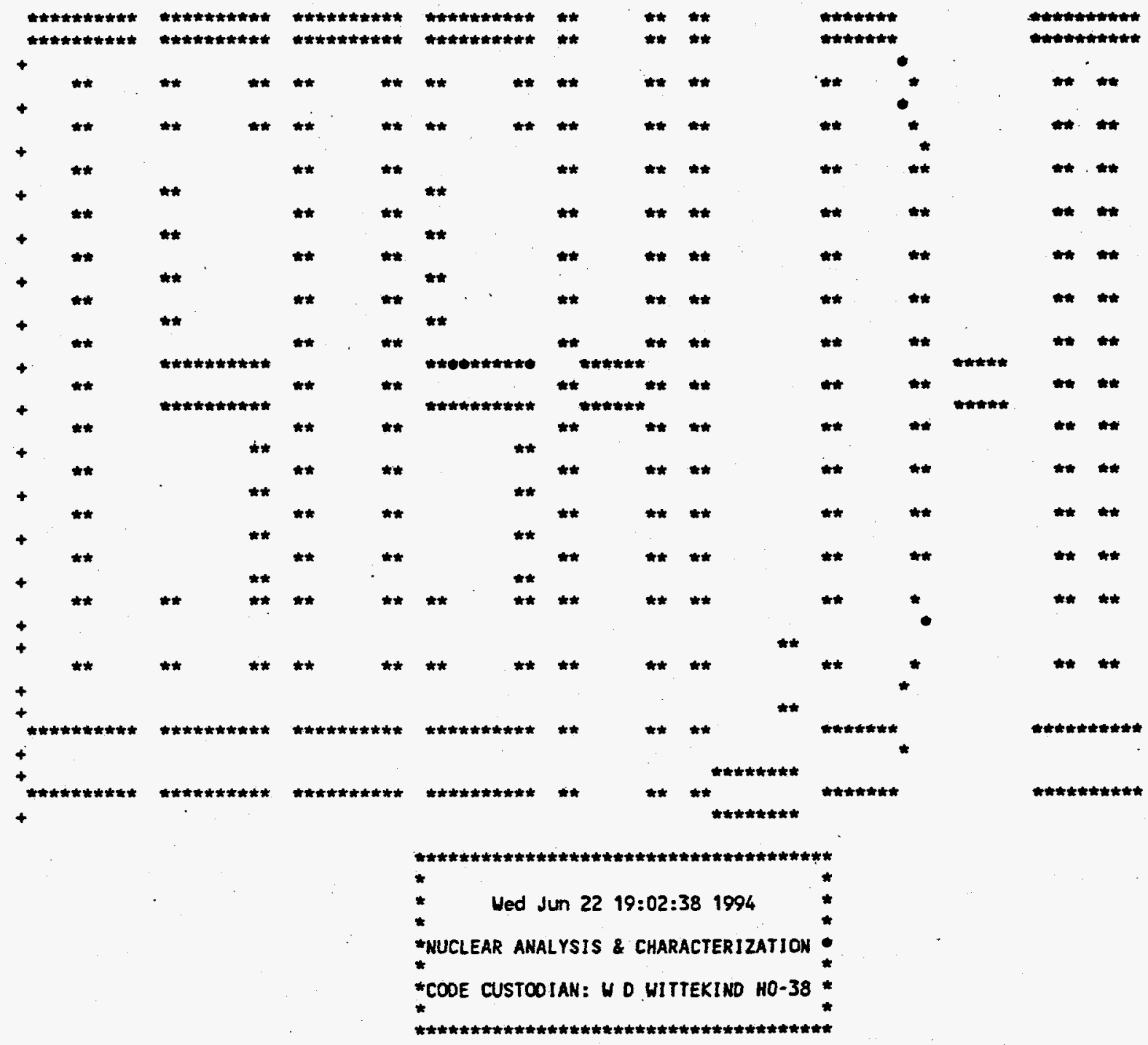

0

BUILD UP TO FULL 1800 CANISTER BASIN

1

POWER $=6.64650 E+03$ MEGAWATTS

IRRADIATION TIME $=4.06000 E+02$ DAYS

PHI*SIG25*TIME $=4.22100 E-01$ N/CM2-S * CH2 * SEC

U-235 ABSORPTION CROSS-SECTION 360.000 BARNS

MEUTRON FLUX $=3.343 E+13$ MEUTRONS/(CM**2 - SEC)

11800 CANISTER IRRADIATION

CON 9.0000E-01, PO 6.6465E+03, TIME 4.0600E+02, T 4.2210E-01, SIGA25 3.6000E+02, DEL 1.0000E-01. $A G * 108 \quad 0.000 E+00 \quad 0.000 E+00 \quad 0.000 E+00 \quad 0.000 E+00 \quad 0.000 E+00 \quad 0.000 E+00 \quad 0.000 E+00 \quad 0.000 E+00 \quad 0.000 E+00 \quad 0.000 E+00 \quad 0.000 E+0 \quad 2$ $A G * 108 \quad 0.000 E+00 \quad 0.000 E+00 \quad 0.000 E+00 \quad 0.000 E+00 \quad 0.000 E+00 \quad 0.000 E+00 \quad 0.000 E+00 \quad 0.000 E+00 \quad 0.000 E+00 \quad 0.000 E+00 \quad 0.000 E+0 \quad 2$

0 $.0 .000+00 \quad 4.550 E+08 \quad 5.410 E+08 \quad 7.140 E+08 \quad 8.870 E+08$ DECAY POINTS - SECONDS

$\begin{array}{lllllll}\text { ZN } & 72 & 3.242 E+03 & 0.000 E+00 & 0.000 E+00 & 0.000 E+00 & 0.000 E+00 \\ \text { GA } & 72 & 3.239 E+03 & 0.000 E+00 & 0.000 E+00 & 0.000 E+00 & 0.000 E+00 \\ \text { GE } & 72 & 0.000 E+00 & 0.000 E+00 & 0.000 E+00 & 0.000 E+00 & 0.000 E+00 \\ \text { ZN } & 73 & 3.275 E+03 & 0.000 E+00 & 0.000 E+00 & 0.000 E+00 & 0.000 E+00 \\ \text { GA } & 73 & 3.343 E+03 & 0.000 E+00 & 0.000 E+00 & 0.000 E+00 & 0.000 E+00 \\ \text { GE } & 73 & 0.000 E+00 & 0.000 E+00 & 0.000 E+00 & 0.000 E+00 & 0.000 E+00 \\ \text { GA } & 74 & 1.170 E+04 & 0.000 E+00 & 0.000 E+00 & 0.000 E+00 & 0.000 E+00 \\ \text { GE } & 74 & 0.000 E+00 & 0.000 E+00 & 0.000 E+00 & 0.000 E+00 & 0.000 E+00 \\ \text { GA } & 75 & 1.337 E+04 & 0.000 E+00 & 0.000 E+00 & 0.000 E+00 & 0.000 E+00 \\ \text { GE* } \frac{15}{75} & 1.337 E+04 & 0.000 E+00 & 0.000 E+00 & 0.000 E+00 & 0.000 E+00 \\ \text { GE } 75 & 2.675 E+04 & 0.000 E+00 & 0.000 E+00 & 0.000 E+00 & 0.000 E+00\end{array}$


WHC-SD-NR-ER-105 Rev. 0

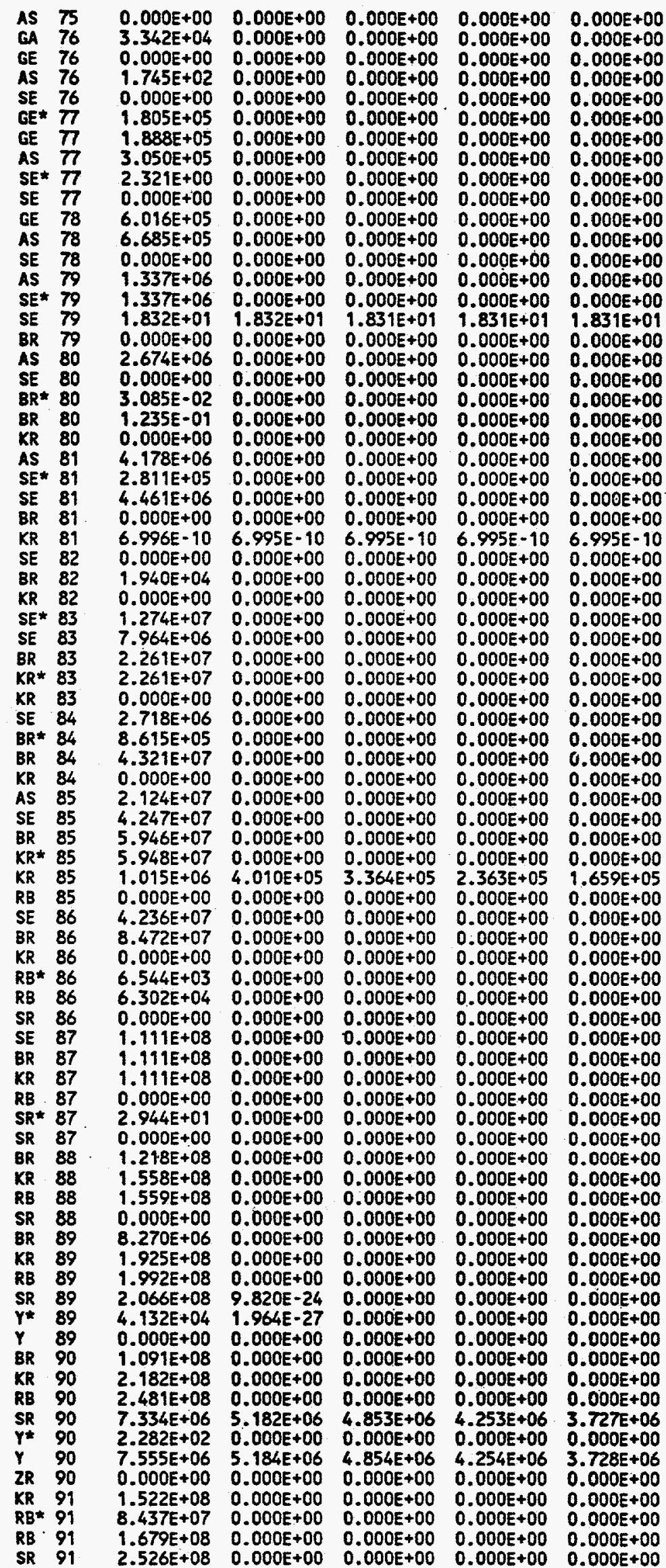


WHC-SD-NR-ER-105 Rev. 0

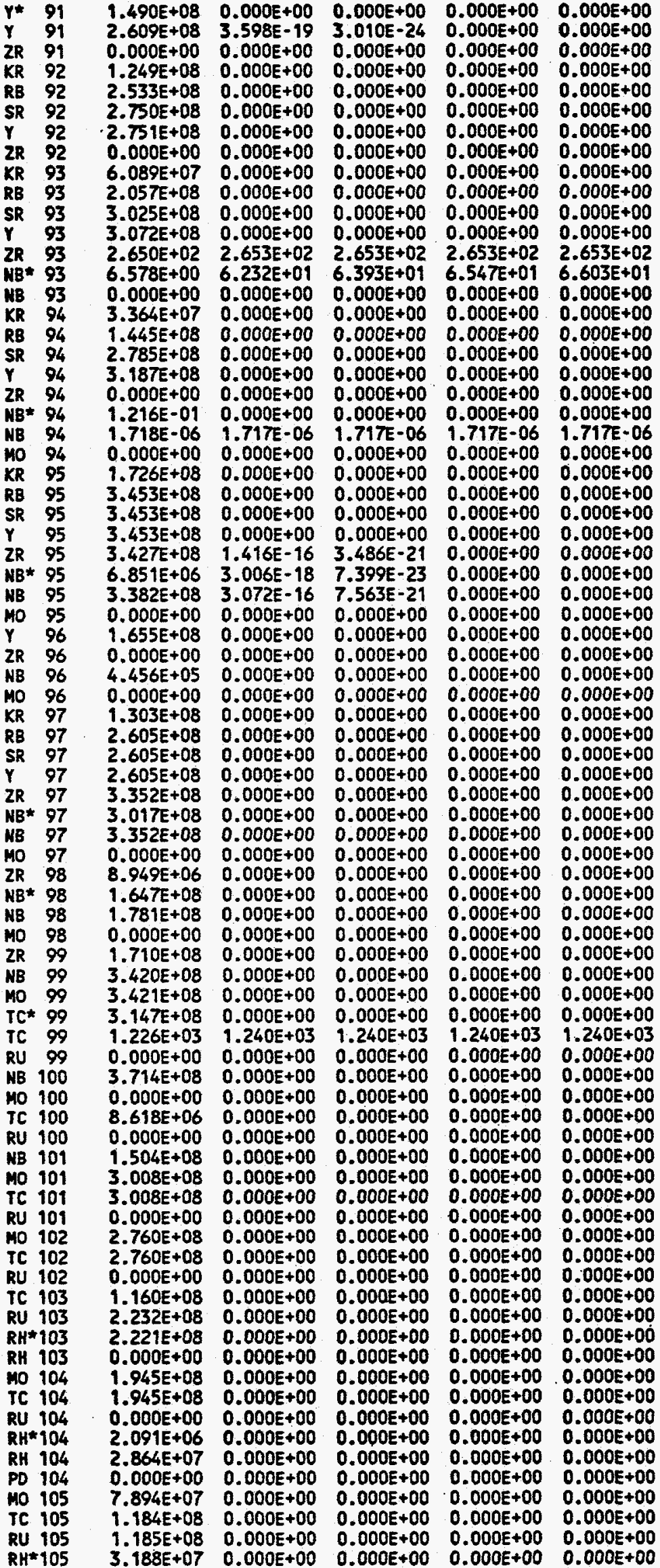


WHC-SD-NR-ER-105 Rev. 0

\begin{tabular}{|c|c|c|c|c|c|}
\hline 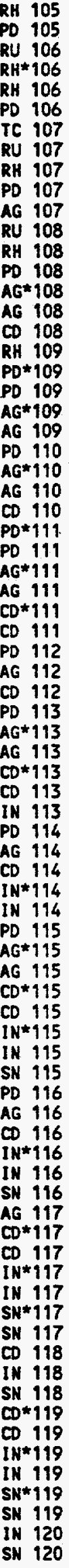 & $\begin{array}{l}1.046 E+08 \\
0.000 E+00 \\
4.656 E+07 \\
9.801 E+06 \\
5.049 E+07 \\
0.000 E+00 \\
8.688 E+07 \\
8.823 E+07 \\
8.823 E+07 \\
6.660 E+00 \\
0.000 E+00 \\
5.024 E+07 \\
5.024 E+07 \\
0.000 E+00 \\
0.000 E+00 \\
1.128 E-01 \\
0.000 E+00 \\
3.264 E+07 \\
3.265 E+07 \\
3.309 E+07 \\
3.309 E+07 \\
0.000 E+00 \\
0.000 E+00 \\
2.713 E+04 \\
2.123 E+06 \\
0.000 E+00 \\
2.598 E+05 \\
5.761 E+06 \\
5.761 E+06 \\
5.766 E+06 \\
1.030 E+02 \\
0.000 E+00 \\
3.081 E+06 \\
3.080 E+06 \\
0.000 E+00 \\
5.941 E+05 \\
5.941 E+05 \\
5.347 E+05 \\
1.768 E+00 \\
0.000 E+00 \\
0.000 E+00 \\
5.607 E+05 \\
5.607 E+05 \\
0.000 E+00 \\
2.840 E-03 \\
4.726 E-03 \\
4.203 E+05 \\
1.177 E+05 \\
3.261 E+05 \\
3.042 E+04 \\
4.166 E+05 \\
4.166 E+05 \\
0.000 E+00 \\
0.000 E+00 \\
3.342 E+05 \\
3.342 E+05 \\
0.000 E+00 \\
7.765 E+04 \\
2.190 E+04 \\
0.000 E+00 \\
6.168 E+05 \\
3.091 E+05 \\
3.084 E+05 \\
3.084 E+05 \\
3.707 E+05 \\
1.181 E+00 \\
0.000 E+00 \\
3.569 E+05 \\
3.569 E+05 \\
0.000 E+00 \\
4.248 E+05 \\
4.248 E+03 \\
4.248 E+03 \\
4.207 E+05 \\
3.106 E+04 \\
0.000 E+00 \\
1.784 E+05\end{array}$ & $\begin{array}{l}0.000 E+00 \\
0.000 E+00 \\
2.117 E+03 \\
0.000 E+00 \\
2.117 E+03 \\
0.000 E+00 \\
0.000 E+00 \\
0.000 E+00 \\
0.000 E+00 \\
6.661 E+00 \\
0.000 E+00 \\
0.000 E+00 \\
0.000 E+00 \\
0.000 E+00 \\
0.000 E+00 \\
0.000 E+00 \\
0.000 E+00 \\
0.000 E+00 \\
0.000 E+00 \\
0.000 E+00 \\
0.000 E+00 \\
0.000 E+00 \\
0.000 E+00 \\
2.175 E-02 \\
4.350 E-04 \\
0.000 E+00 \\
0.000 E+00 \\
0.000 E+00 \\
0.000 E+00 \\
0.000 E+00 \\
0.000 E+00 \\
0.000 E+00 \\
0.000 E+00 \\
0.000 E+00 \\
0.000 E+00 \\
0.000 E+00 \\
0.000 E+00 \\
0.000 E+00 \\
8.655 E-01 \\
0.000 E+00 \\
0.000 E+00 \\
0.000 E+00 \\
0.000 E+00 \\
0.000 E+00 \\
5.681 E-35 \\
5.681 E-35 \\
0.000 E++00 \\
0.000 E+00 \\
0.000 E+00 \\
0.000 E+00 \\
0.000 E+00 \\
0.000 E+00 \\
0.000 E+00 \\
0.000 E+00 \\
0.000 E+00 \\
0.000 E+00 \\
0.000 E+00 \\
0.000 E+00 \\
0.000 E+00 \\
0.000 E+00 \\
0.000 E+00 \\
0.000 E+00 \\
0.000 E+00 \\
0.000 E+00 \\
0.000 E+00 \\
0.000 E+00 \\
0.000 E+00 \\
0.000 E+00 \\
0.000 E+00 \\
0.000 E+00 \\
0.000 E+00 \\
0.00 \\
\end{array}$ & $\begin{array}{l}0.000 E+00 \\
0.000 E+00 \\
3.199 E+02 \\
0.000 E+00 \\
3.199 E+02 \\
0.000 E+00 \\
0.000 E+00 \\
0.000 E+00 \\
0.000 E+00 \\
6.661 E+00 \\
0.000 E+00 \\
0.000 E+00 \\
0.000 E+00 \\
0.000 E+00 \\
0.000 E+00 \\
0.000 E+00 \\
0.000 E+00 \\
0.000 E+00 \\
0.000 E+00 \\
0.000 E+00 \\
0.000 E+00 \\
0.000 E+00 \\
0.000 E+00 \\
1.532 E-03 \\
3.064 E-05 \\
0.000 E+00 \\
0.000 E+00 \\
0.000 E+00 \\
0.000 E+00 \\
0.000 E+00 \\
0.000 E+00 \\
0.000 E+00 \\
0.000 E+00 \\
0.000 E+00 \\
0.000 E+00 \\
0.000 E+00 \\
0.000 E+00 \\
0.000 E+00 \\
7.562 E=01 \\
0.000 E+00 \\
0.000 E+00 \\
0.000 E+00 \\
0.000 E+00 \\
0.000 E+00 \\
0.000 E+00 \\
0.000 E+00 \\
0.000 E+00 \\
0.000 E+00 \\
0.000 E+00 \\
0.000 E+00 \\
0.000 E+00 \\
0.000 E+00 \\
0.000 E+00 \\
0.000 E+00 \\
0.000 E+00 \\
0.000 E+00 \\
0.000 E+00 \\
0.000 E+00 \\
0.000 E+00 \\
0.000 E+00 \\
0.000 E+00 \\
0.000 E+00 \\
0.000 E+00 \\
0.000 E+00 \\
0.000 E+00 \\
0.000 E+00 \\
0.000 E+00 \\
0.000 E+00 \\
0.000 E+00 \\
0.000 E+00 \\
0.000 E+00 \\
0.000 E+00 \\
0.000 E+00 \\
0.000 E+00 \\
8.097 E-04 \\
0.000 E+00 \\
0.000 E+00 \\
0.000 E+00\end{array}$ & $\begin{array}{l}0.000 E+00 \\
0.000 E+00 \\
7.144 E+00 \\
0.000 E+00 \\
7.144 E+00 \\
0.000 E+00 \\
0.000 E+00 \\
0.000 E+00 \\
0.000 E+00 \\
6.661 E+00 \\
0.000 E+00 \\
0.000 E+00 \\
0.000 E+00 \\
0.000 E+00 \\
0.000 E+00 \\
0.000 E+00 \\
0.000 E+00 \\
0.000 E+00 \\
0.000 E+00 \\
0.000 E+00 \\
0.000 E+00 \\
0.000 E+00 \\
0.000 E+00 \\
7.370 E-06 \\
1.474 E-07 \\
0.000 E+00 \\
0.000 E+00 \\
0.000 E+00 \\
0.000 E+00 \\
0.000 E+00 \\
0.000 E+00 \\
0.000 E+00 \\
0.000 E+00 \\
0.000 E+00 \\
0.000 E+00 \\
0.000 E+00 \\
0.000 E+00 \\
0.000 E+00 \\
5.764 E-01 \\
0.000 E+00 \\
0.000 E+00 \\
0.000 E+00 \\
0.000 E+00 \\
0.000 E+00 \\
0.000 E+00 \\
0.000 E+00 \\
0.000 E+00 \\
0.000 E+00 \\
0.000 E+00 \\
0.000 E+00 \\
0.000 E+00 \\
0.000 E+00 \\
0.000 E+00 \\
0.000 E+00 \\
0.000 E+00 \\
0.000 E+00 \\
0.000 E+00 \\
0.000 E+00 \\
0.000 E+00 \\
0.000 E+00 \\
0.000 E+00 \\
0.000 E+00 \\
0.000 E+00 \\
0.000 E+00 \\
0.000 E+00 \\
0.000 E+00 \\
0.000 E+00 \\
0.000 E+00 \\
0.000 E+00 \\
0.000 E+00 \\
0.000 E+00 \\
0.000 E+00 \\
0.000 E+00 \\
0.000 E+00 \\
3.496 E-06 \\
0.000 E+00 \\
0.000 E+00 \\
0.000 E+00\end{array}$ & $\begin{array}{l}0.000 E+00 \\
1.595 E-01 \\
0.000 E+00 \\
1.595 E-01 \\
0.000 E+00 \\
0.000 E+00 \\
0.000 E+00 \\
0.000 E+00 \\
6.061 E+00 \\
0.000 E+00 \\
0.000 E+00 \\
0.000 E+00 \\
0.000 E+00 \\
0.000 E+00 \\
0.000 E+00 \\
0.000 E+00 \\
0.000 E+00 \\
0.000 E+00 \\
0.000 E+00 \\
0.000 E+00 \\
0.000 E+00 \\
0.000 E+00 \\
3.546 E-08 \\
7.091 E-90 \\
0.000 E+00 \\
0.000 E+00 \\
0.000 E+00 \\
0.000 E+00 \\
0.000 E+00 \\
0.000 E+00 \\
0.000 E+00 \\
0.000 E+00 \\
0.000 E+00 \\
0.000 E+00 \\
0.000 E+00 \\
0.000 E+00 \\
0.000 E+00 \\
4.393 E-0 \\
0.000 E+00 \\
0.000 E+00 \\
0.000 E+00 \\
0.000 E+00 \\
0.000 E+00 \\
0.000 E+00 \\
0.000 E+00 \\
0.000 E+00 \\
0.000 E+00 \\
0.000 E+00 \\
0.000 E+00 \\
0.000 E+00 \\
0.000 E+00 \\
0.000 E+00 \\
0.000 E+00 \\
0.000 E+00\end{array}$ \\
\hline
\end{tabular}


WHC-SD-NR-ER-105 Rev. 0

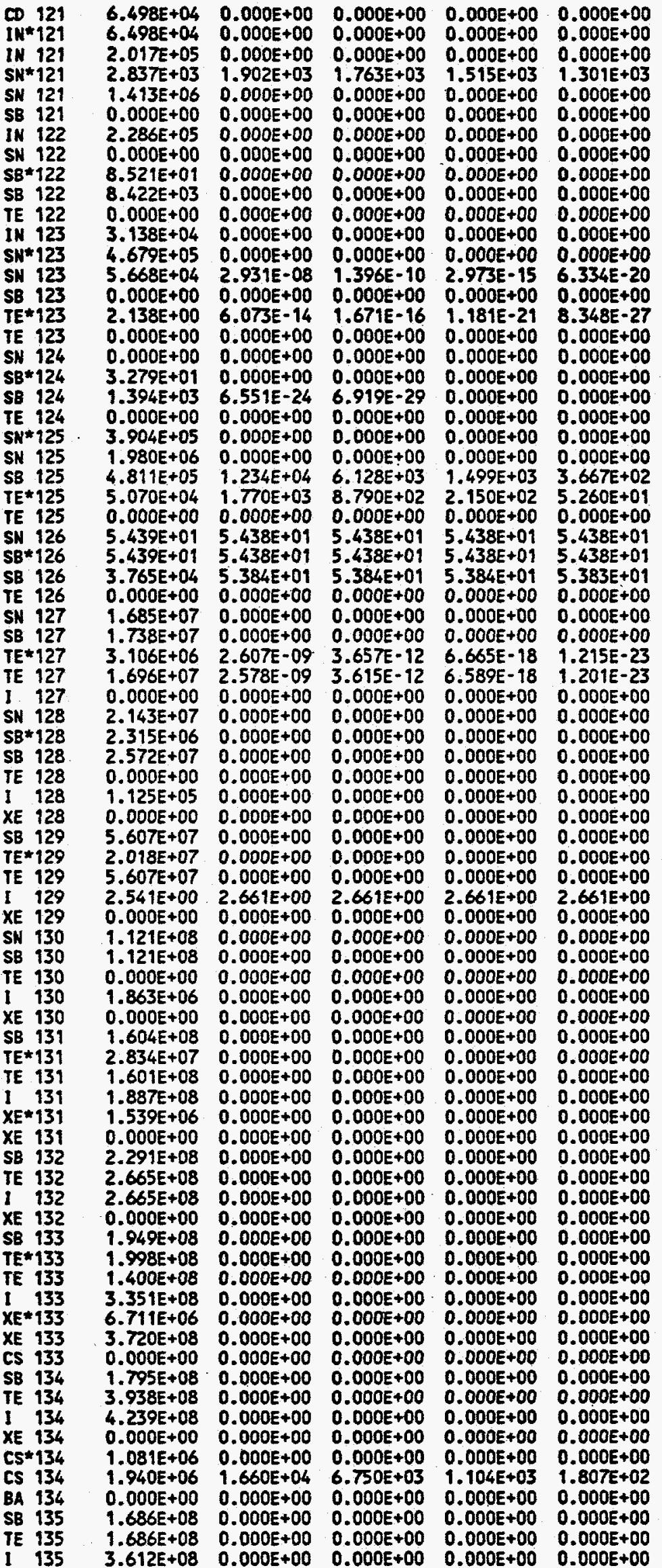


WHC-SD-NR-ER-105 ReV. 0

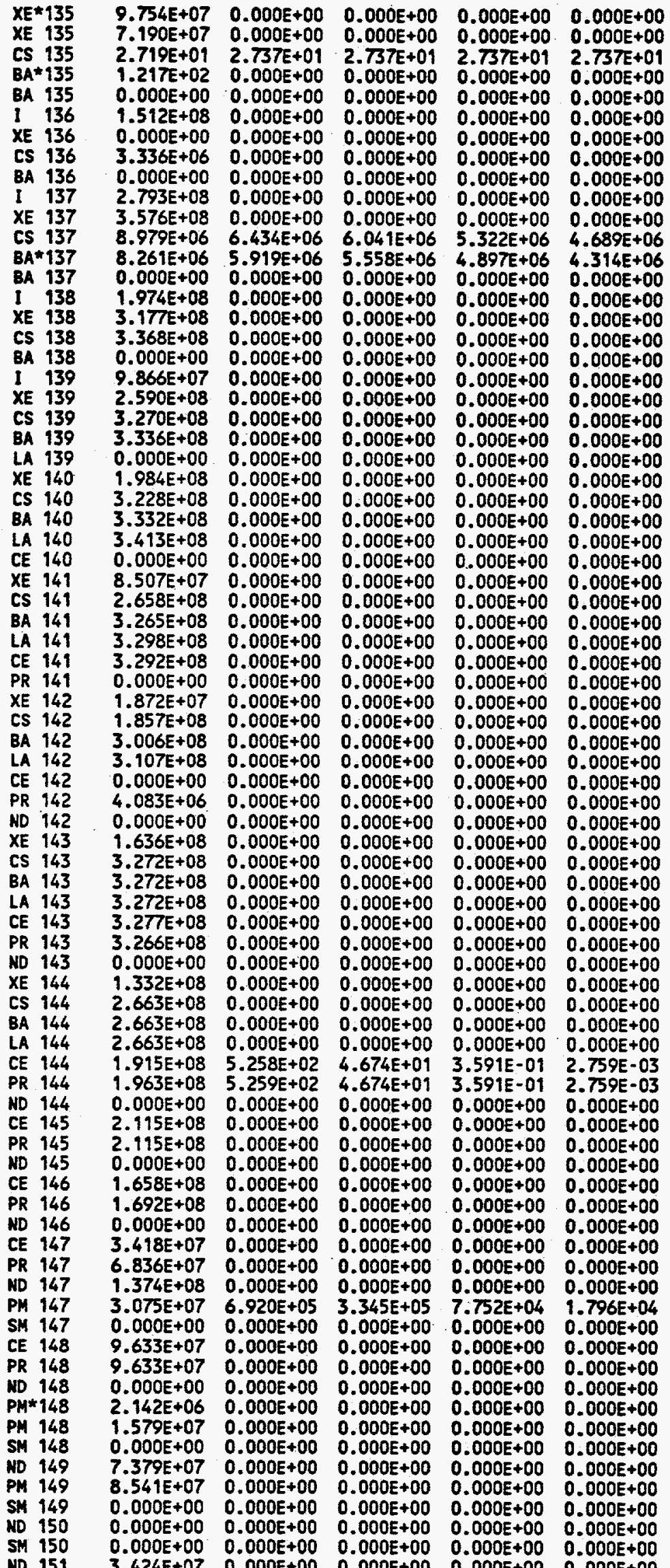




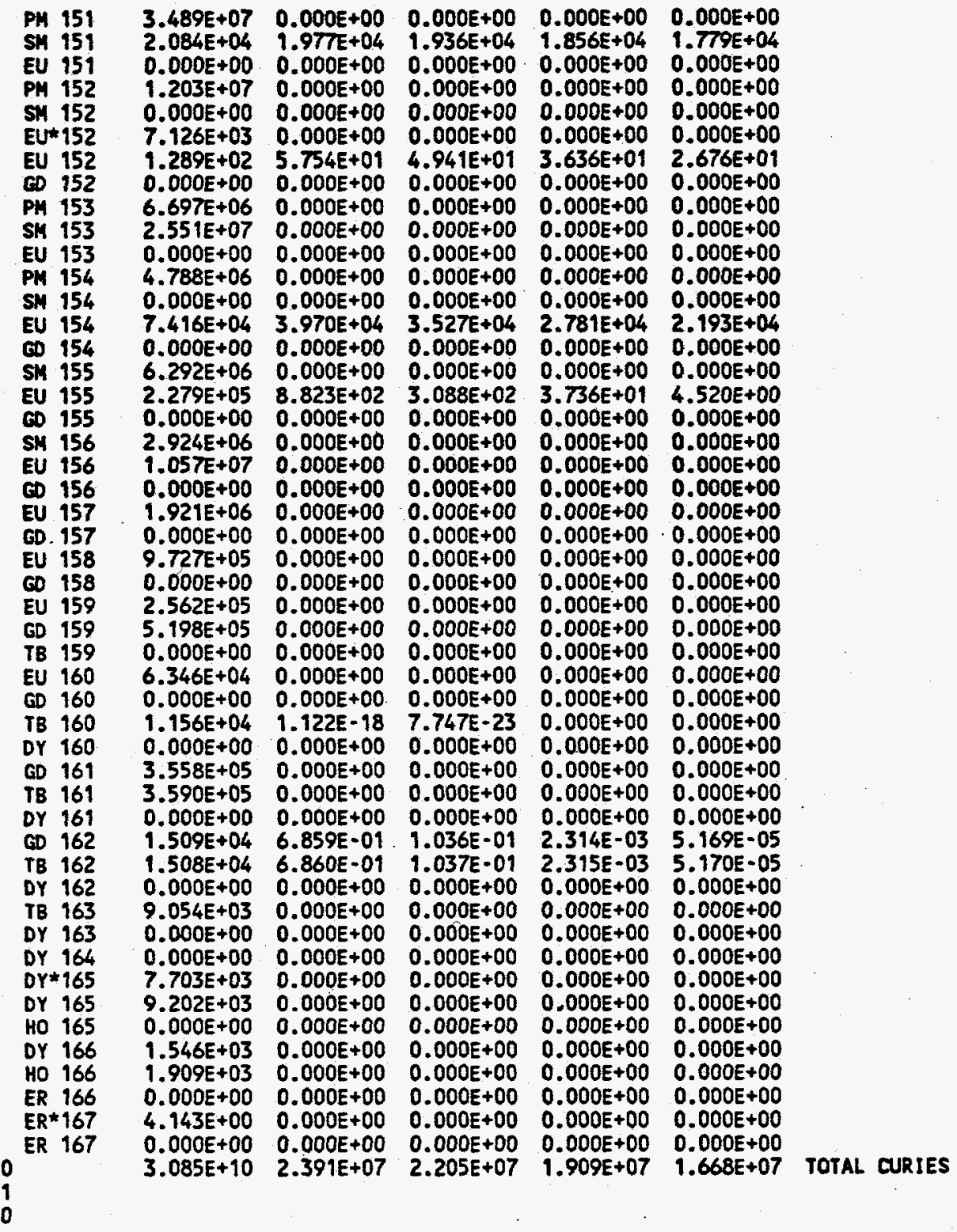

ISOTOPE SELECTION DATA 
WHC-SD-NR-ER-105 Rev. 0

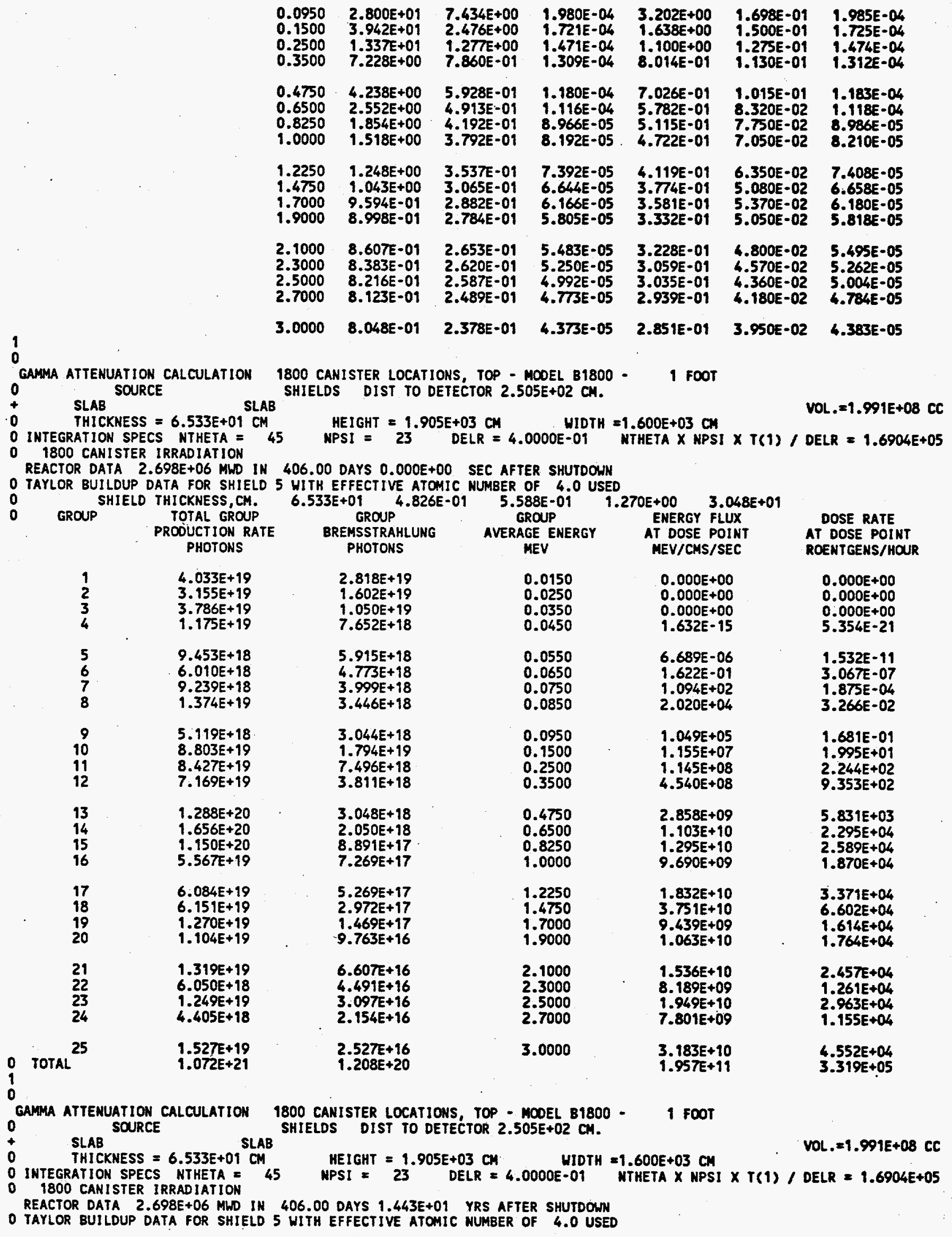


WHC-SD-NR-ER-105 Rev. 0

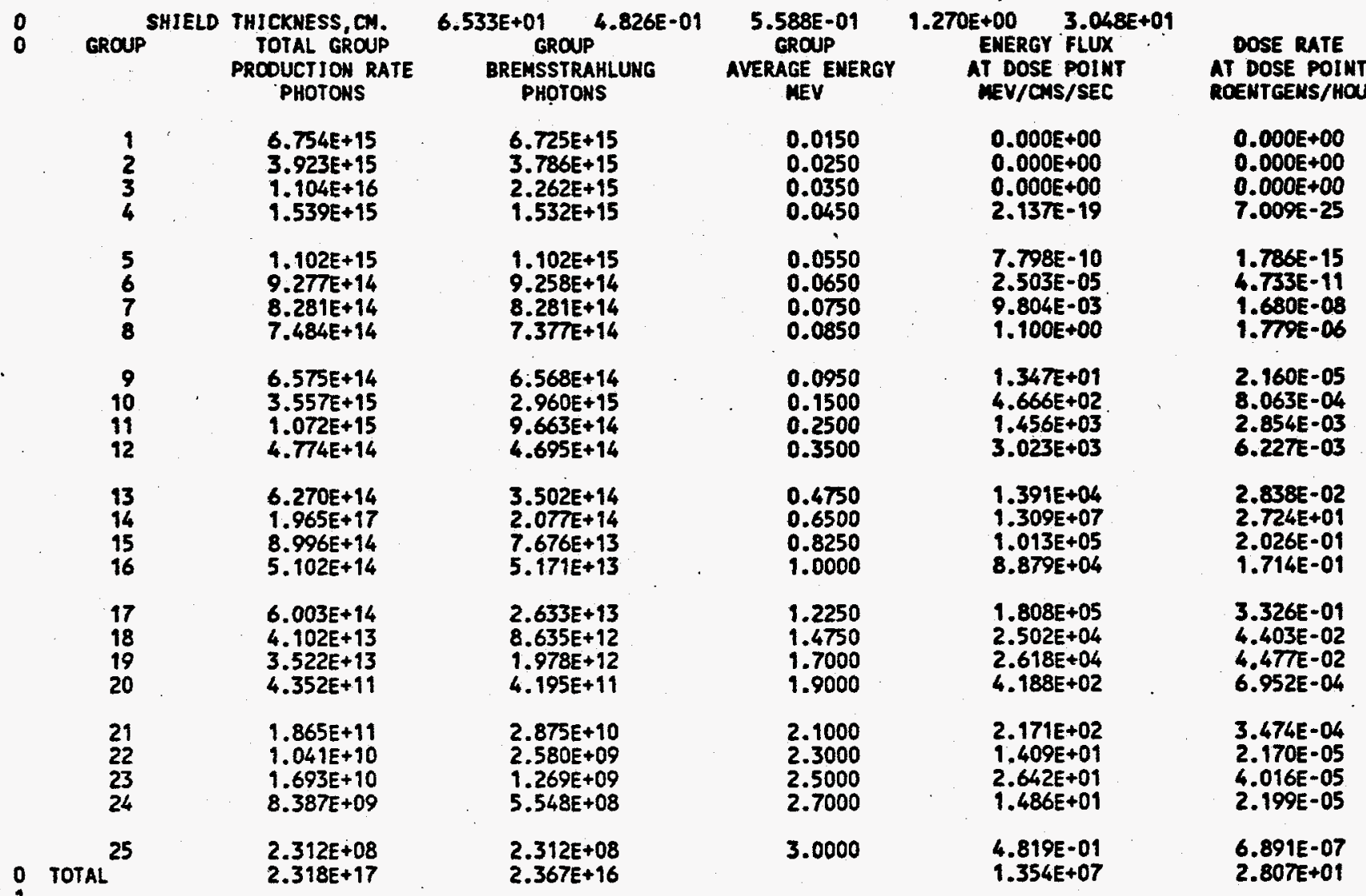

GAMMA ATTENUATION CALCULATION 1800 CANISTER LOCATIONS; TOP - MOOEL B1800 - 1 FOOT

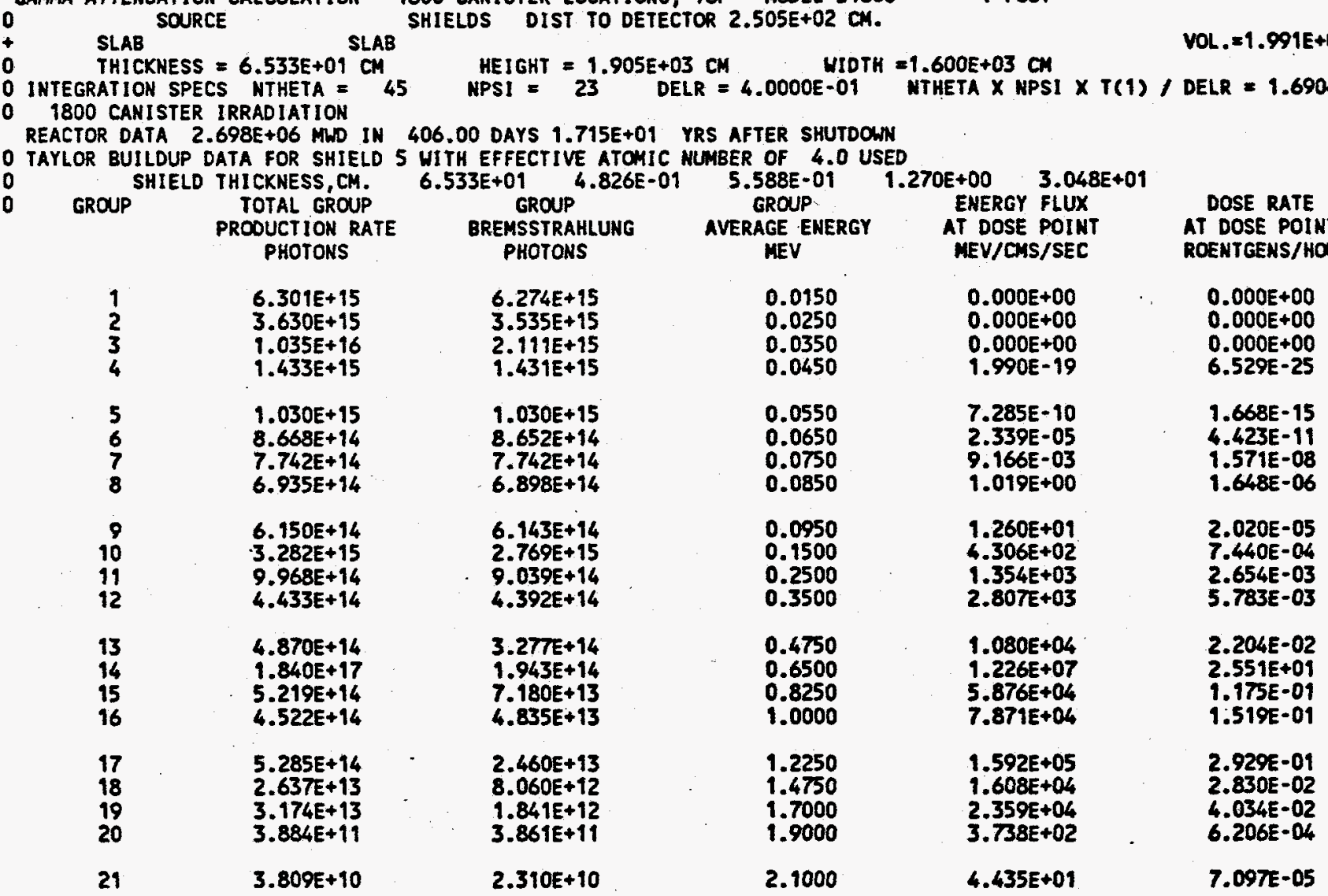




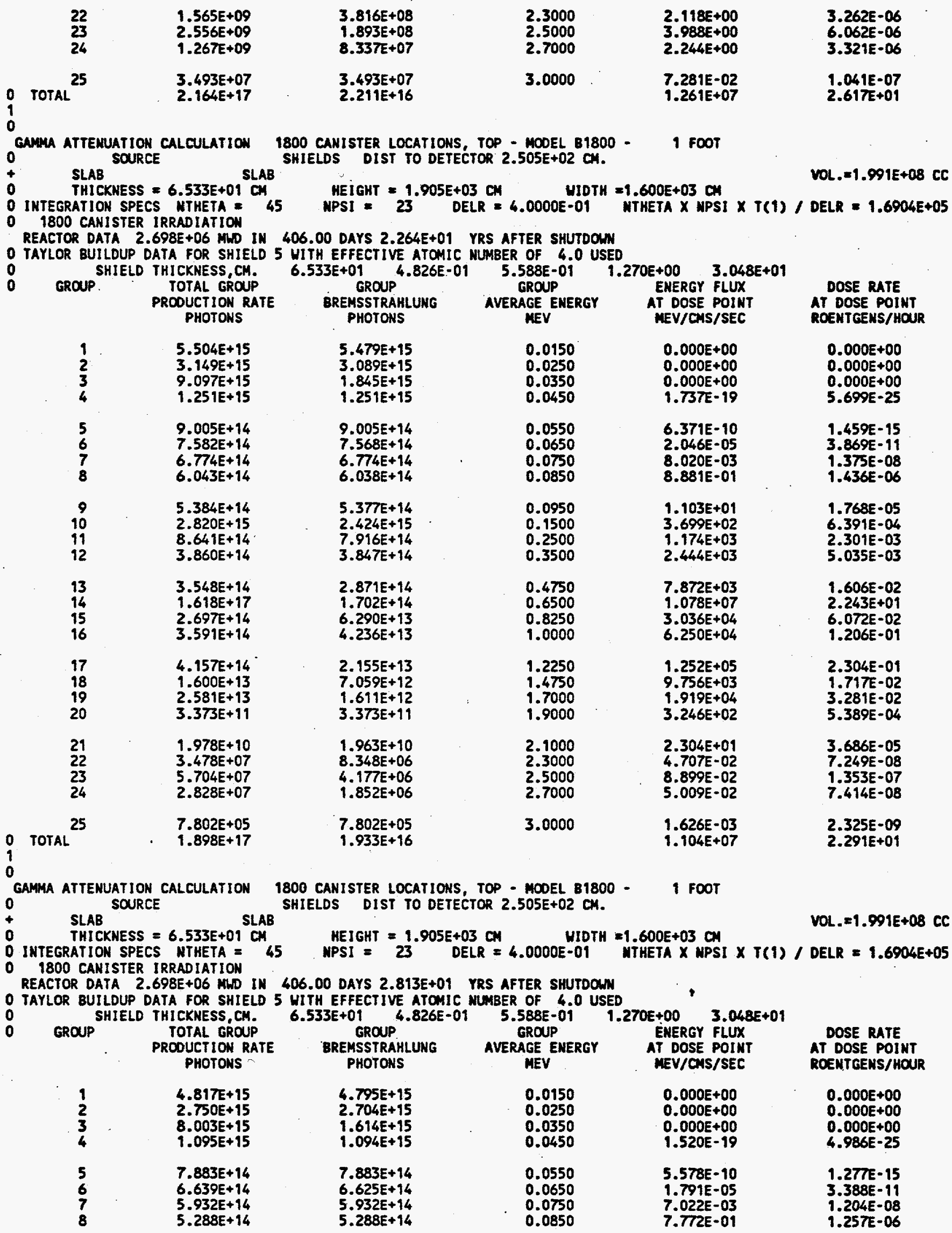




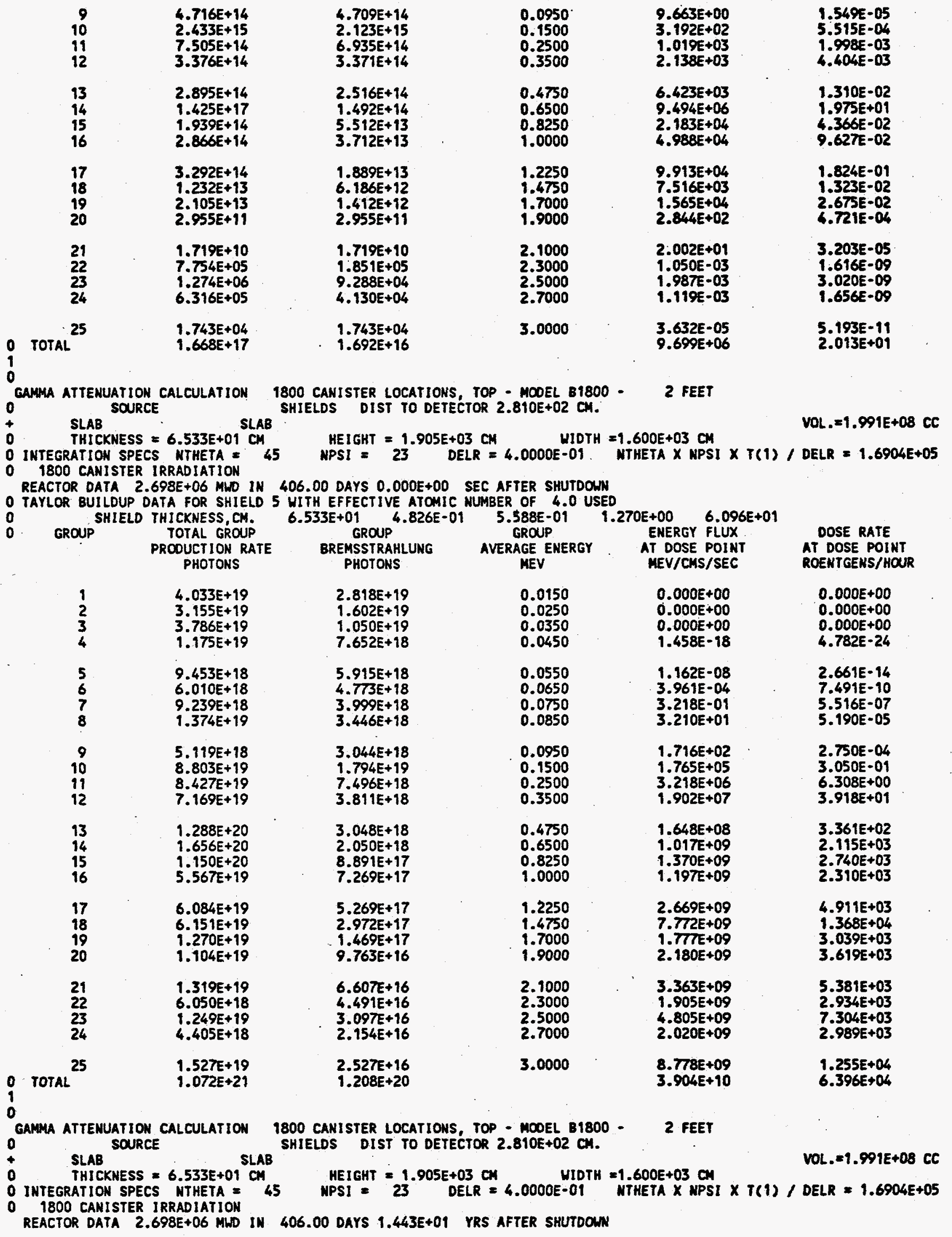


WHC-SD-NR-ER-105 Rev. 0

O TAYLOR BUILOUP DATA FOR SHIELD 5 UITH EFFECTIVE ATOMIC MUMBER OF 4.0 USED

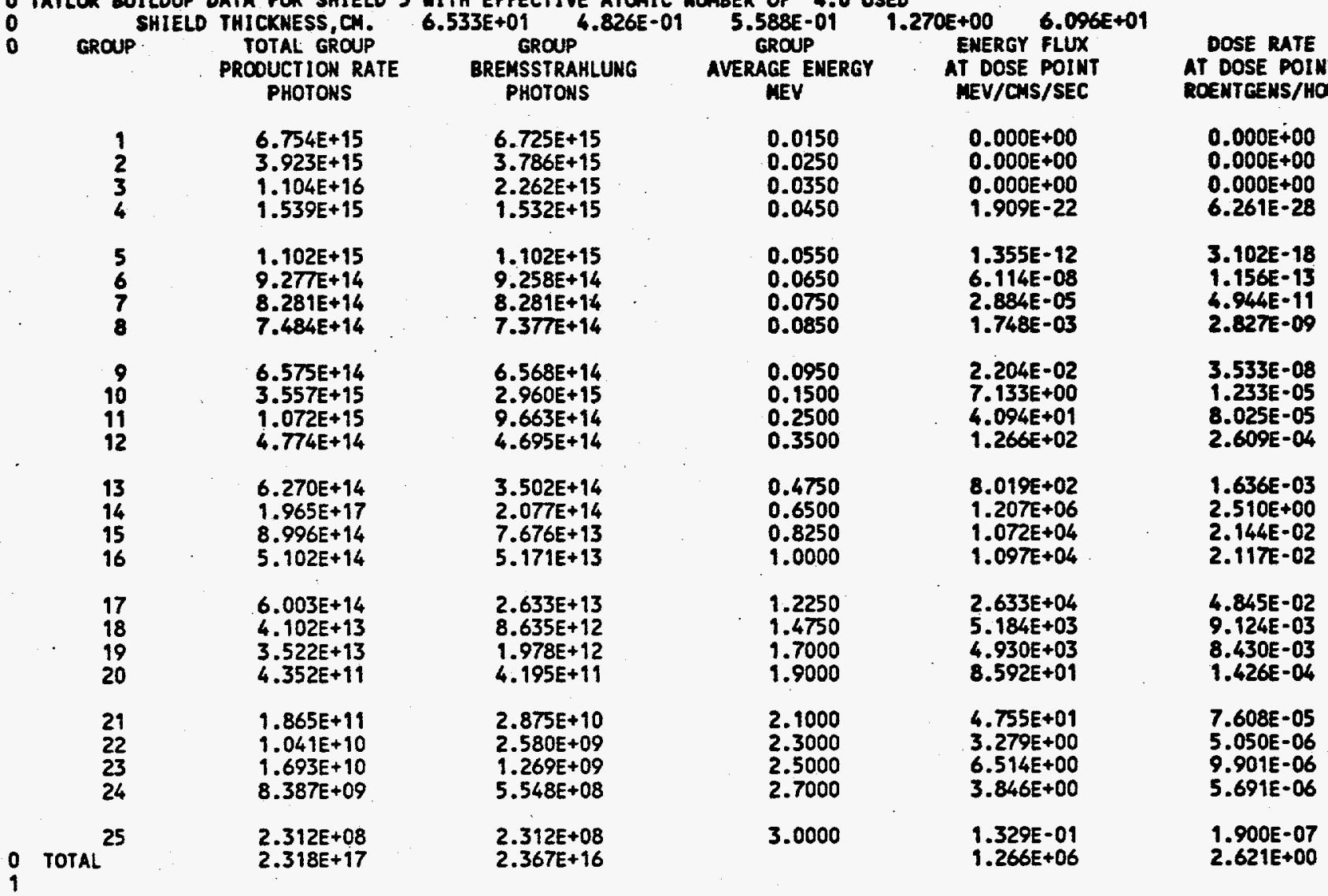

Gamma attenuATION CALCULATION 1800 CANISTER lOCATIONS, TOP - MOOEL B1800 - 2 fEet

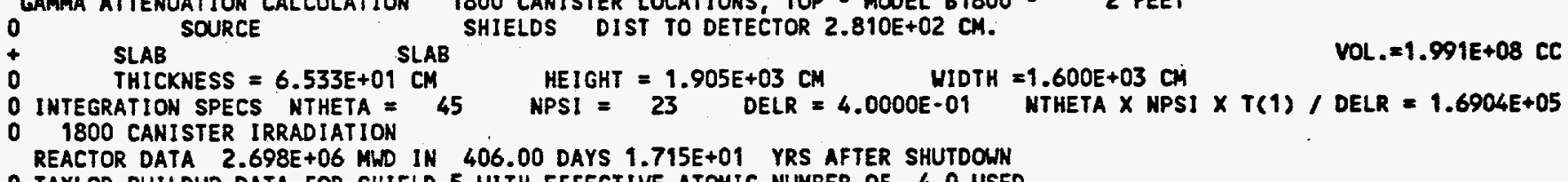

REACTOR DATA 2.698E+06 MWD IN 406.00 DAYS $1.795 E+01$ YRS AFTER SHUTDOWN

0 TAYLOR BUILDUP DATA FOR SHIELD 5 WITH EFFECTIVE ATOMIC NUMBER OF 4.0 USED
0
SHIELD THICKNESS, CM.

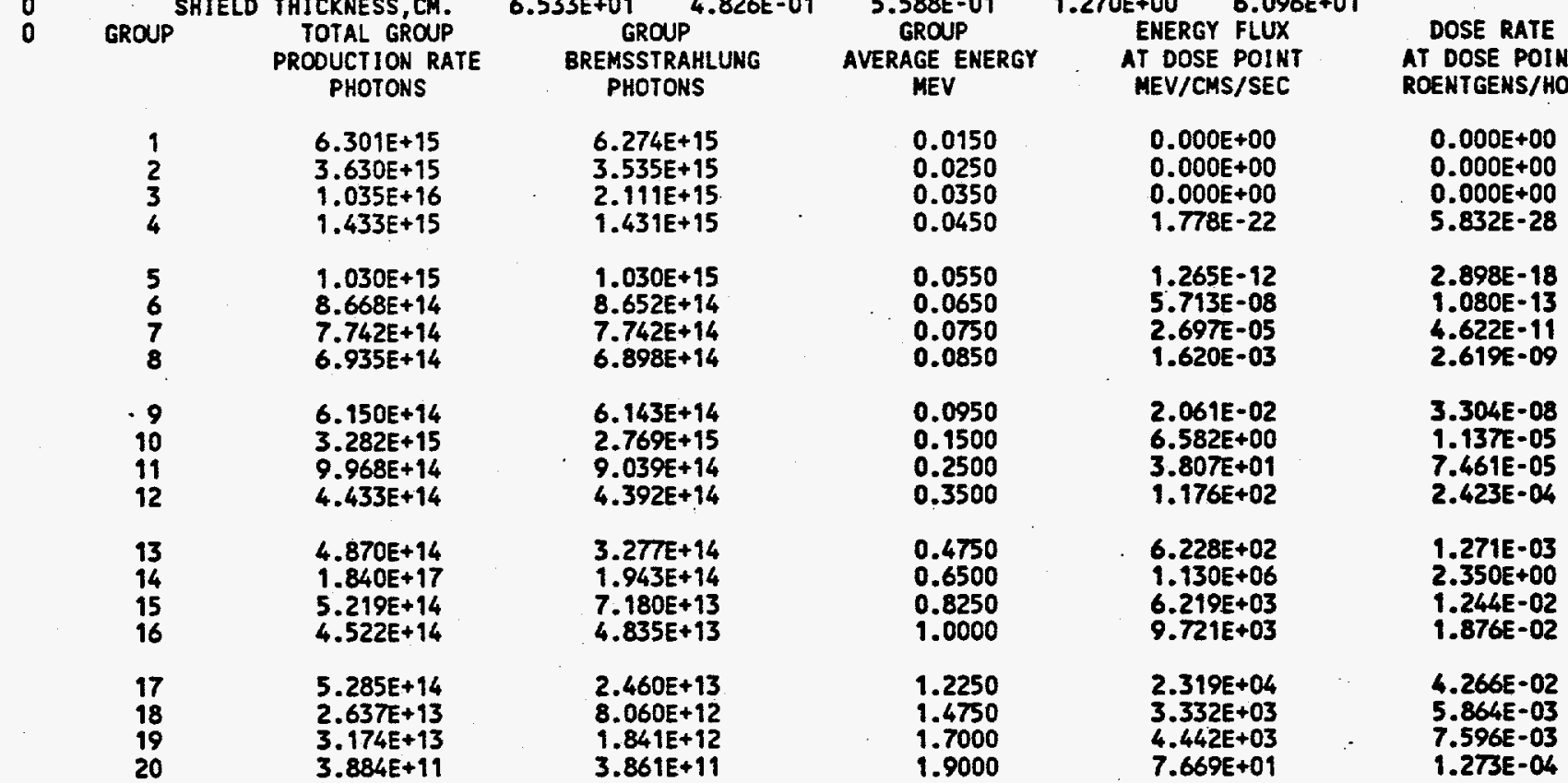




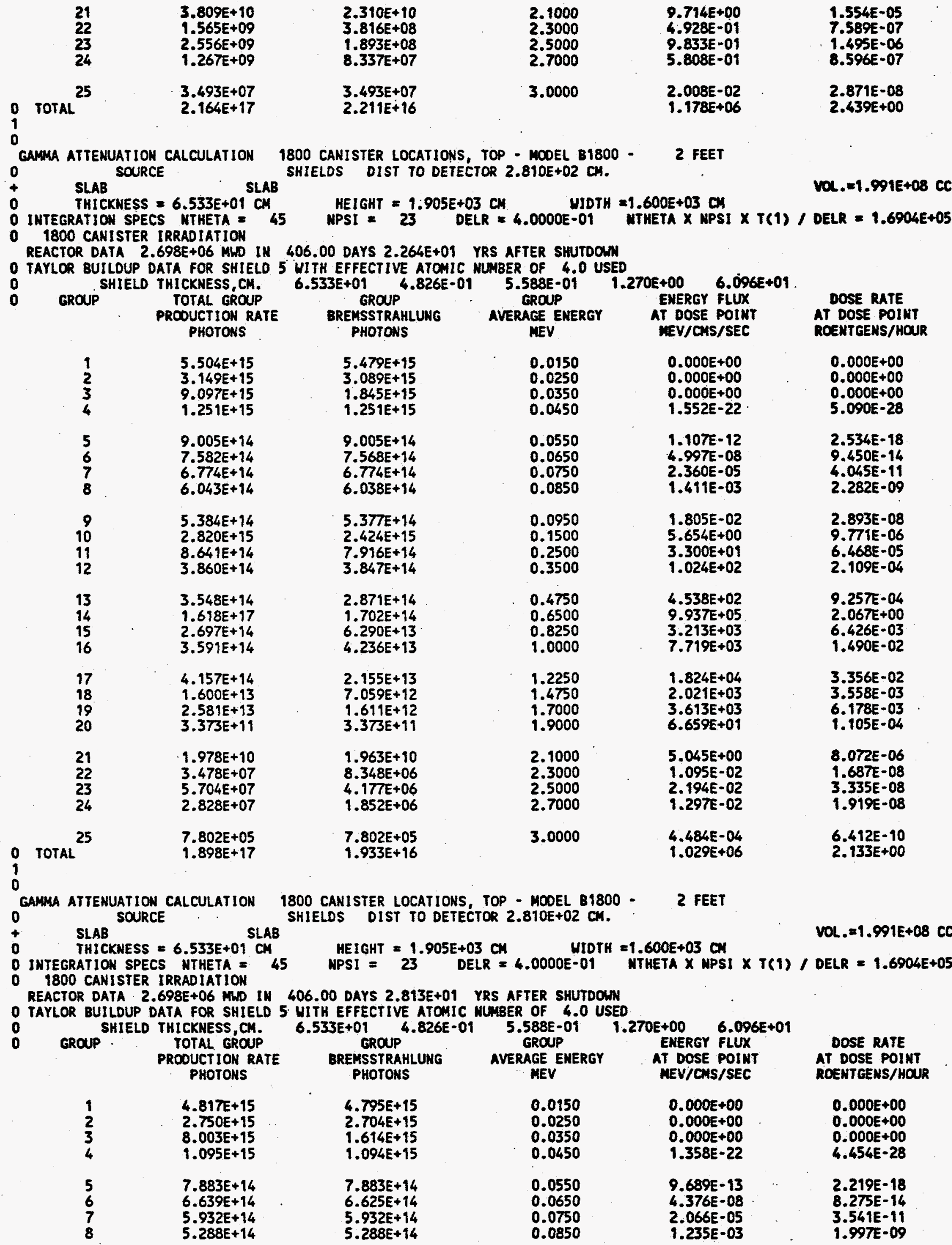


WHC-SD-NR-ER-105 Rev. 0

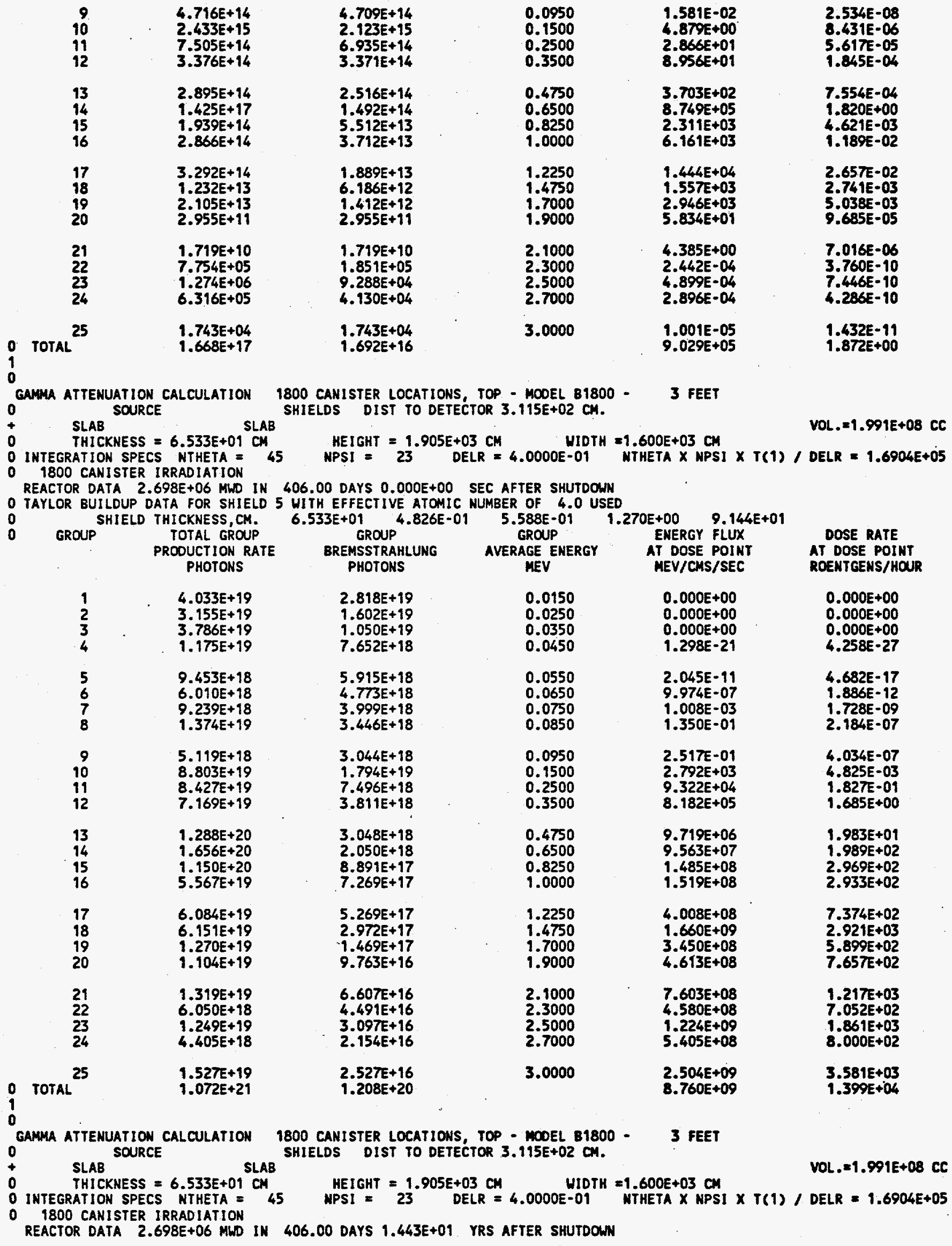


WHC-SD-NR-ER-105 ReV. 0

O TAYLOR BUILDUP DATA FOR SHIELO 5 MITH EFFECTIVE ATONIC MUHER OF 4.0 USED

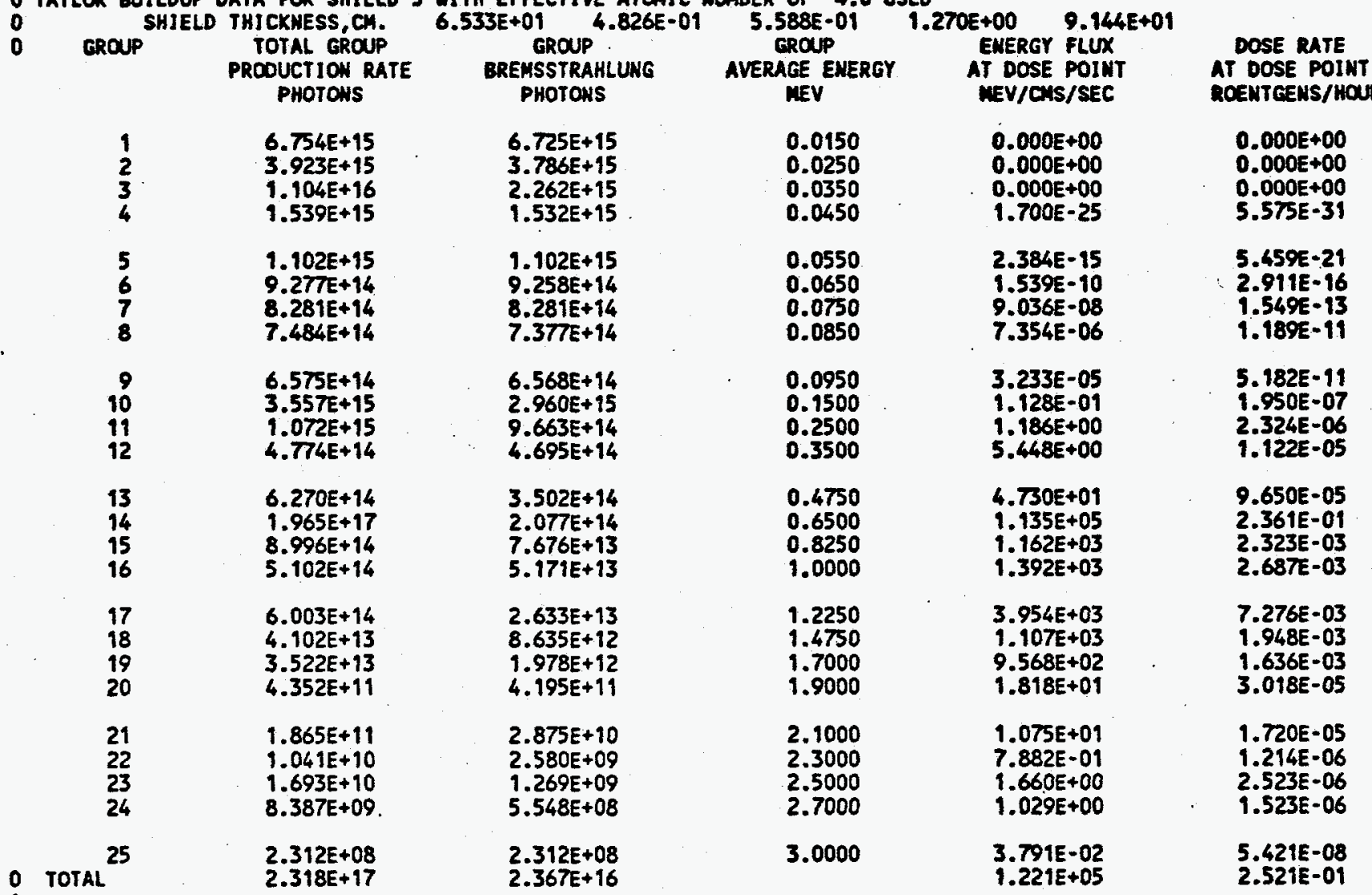

1

gaMma attenuation CALCULATION 1800 CANISTER LOCATIONS, TOP - MODEL 81800 O SOURCE SHIELDS DIST TO DETECTOR $3.115 E+02$ CM.

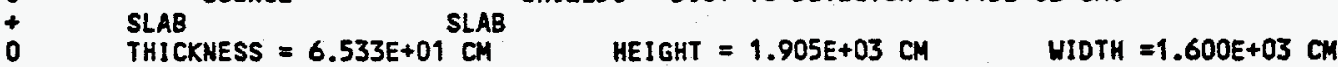

3 FEET

0 INTEGRATION SPECS NTHETA $=45$ MPSI $=23$ DELR $=4.0000 E-01$ NTHETA $\times$ MPSI $\times$ T(1) $/$ DELR $=1.6904 E+05$

O 1800 CANISTER IRRADIATION

REACTOR DATA 2.698E+06 MWO IN 406.00 DAYS 1.715E+01 YRS AFTER SHUTDOWN

D TAYLOR BUILDUP DATA FOR SHIELD 5 WITH EFFECTIVE ATOMIC MUMBER OF 4.0 USED

O SHIELD THICKNESS, CM. $6.533 \mathrm{E}+01 \quad 4.826 \mathrm{E}-01 \quad 5.588 E-01 \quad 1.270 E+00 \quad 9.144 E+01$ GROUP
PROTALTION RATE
PHOTONS GROUP

BREMSSTRAHLUNG PHOTONS GROUP AVERAGE ENERGY ENERGY FLUX MEV MEV/CHS/SEC

DOSE RATE AT DOSE POINT

$\begin{array}{cc}1 & 6.301 E+15 \\ 2 & 3.630 E+15 \\ 3 & 1.035 E+16 \\ 4 & 1.433 E+15 \\ 5 & 1.030 E+15 \\ 6 & 8.668 E+14 \\ 7 & 7.742 E+14 \\ 8 & 6.935 E+14 \\ 9 & 6.150 E+14 \\ 9 & 3.282 E+15 \\ 10 & 9.968 E+14 \\ 11 & 4.433 E+14 \\ 12 & \\ 13 & 4.870 E+14 \\ 14 & 1.840 E+17 \\ 15 & 5.219 E+14 \\ 16 & 4.522 E+14 \\ 17 & 5.285 E+14 \\ 18 & 2.637 E+13 \\ 19 & 3.174 E+13 \\ 20 & 3.884 E+11\end{array}$

6.274E+15

$3.535 E+15$

2.111E+15

$1.431 E+15$

$1.030 E+15$

$8.652 E+14$

$7.742 E+14$

$6.898 E+14$

$6.143 E+14$

$2.769 E+15$

$9.039 E+14$

$4.392 E+14$

\section{$3.277 E+14$}

$1.943 E+14$

$7.180 E+13$

$4.835 \mathrm{E}+13$

$2.460 E+13$

$8.060 E+12$

$1.841 E+12$

$3.861 E+11$

0.0150
0.0250
0.0350
0.0450
0.0550
0.0650
0.0750
0.0850
0.0950
0.1500
0.2500
0.3500
0.4750
0.6500
0.8250
1.0000
1.2250
1.4750
1.7000
1.9000

$0.000 E+00$

$0.000 E+00$

$0.000 E+00$

$1.583 E-25$

$2.227 \mathrm{E}-15$

$1.438 \mathrm{E}-10$

8.448E-08

$6.814 E-06$

3.024E-05

$1.041 E-01$

$1.103 E+00$

5.060E+00

3.674E+01

$1.063 E+05$

$6.738 E+02$

$1.234 E+03$

$3.481 E+03$

$7.114 E+02$

$8.622 E+02$

$1.623 E+01$
ROENTGENS/HOUR

$0.000 E+00$
$0.000 E+00$
$0.000 E+00$
$5.193 E-31$

5.100E-21

$2.720 E-16$

$1.448 E-13$

1.102E- 11

$4.847 E-11$

1.799E-07

2.161E-06

1.042E-05

7.495E-05

2.211E-01

$1.348 E-03$

2.382E-03

6.406E-03

$1.252 E-03$

$1.474 E-03$

2.694E-05 
WHC-SD-NR-ER-105 Rev. 0

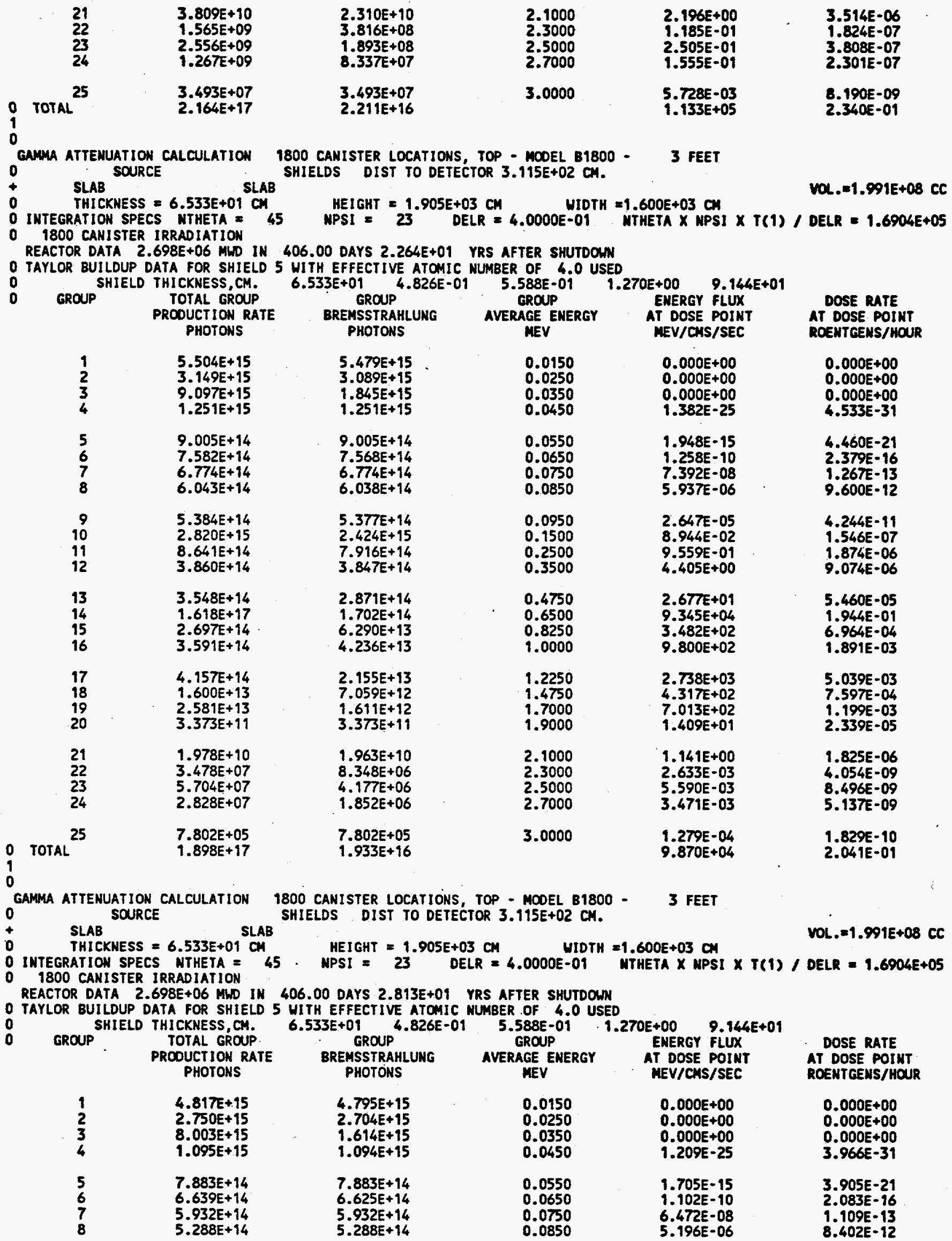


WHC-SD-NR-ER-105 Rev. 0

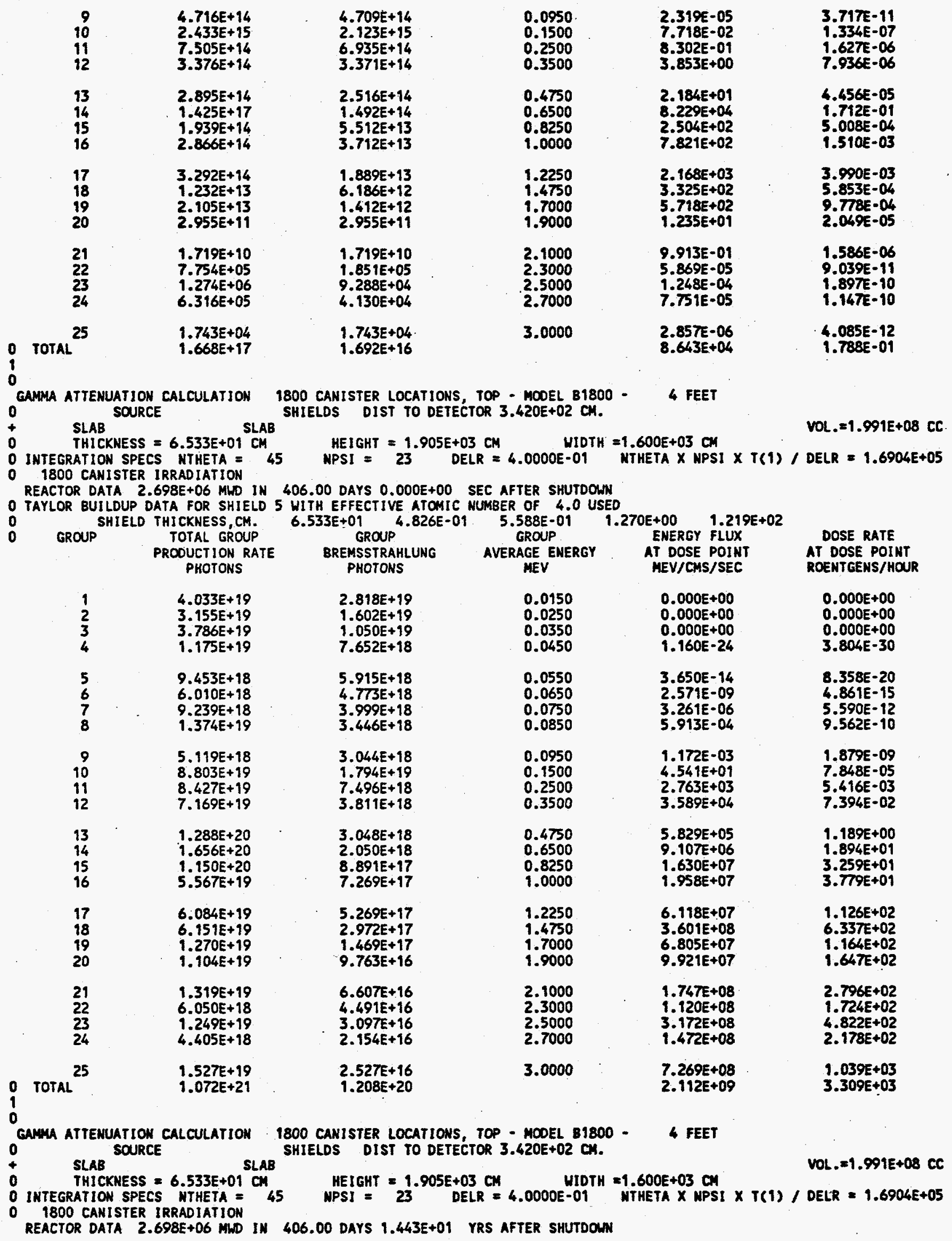


WHC-SD-NR-ER-105 ReV. 0

O TAYLOR BUILDUP DATA FOR SHIELD 5 WITH EFFECTIVE ATONIC MUABER OF 4.0 USED

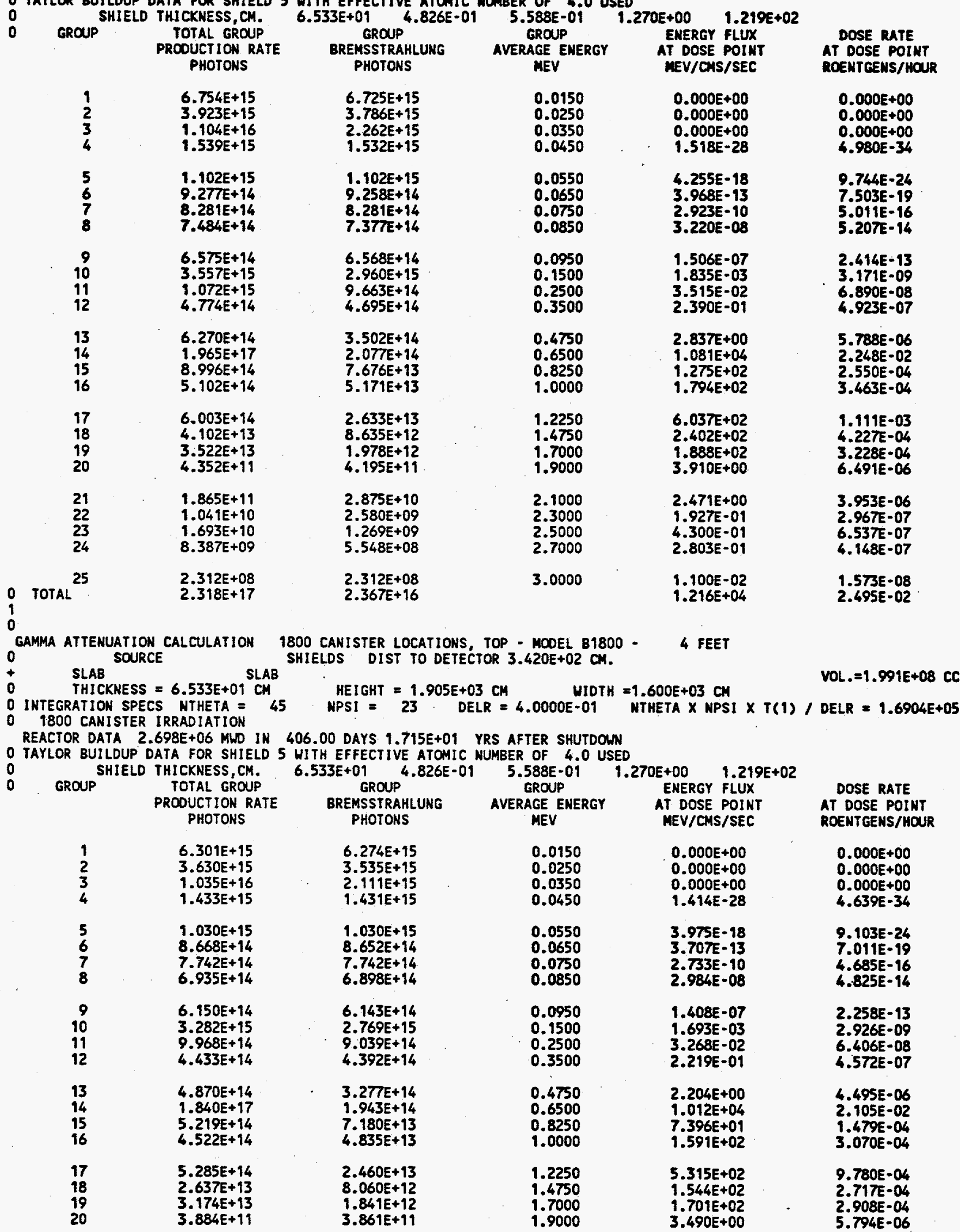


WHC-SD-NR-ER-105 Rev. 0

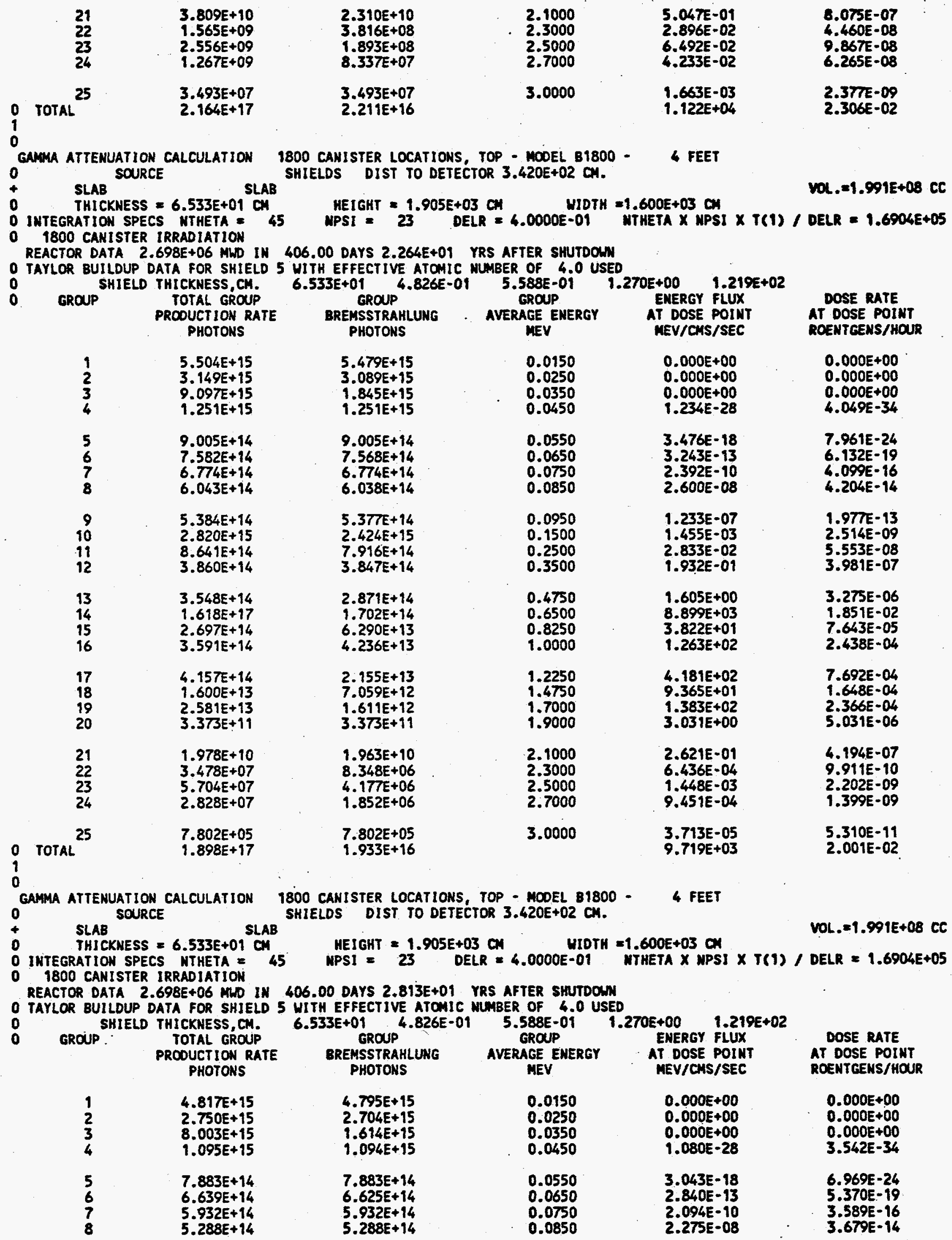


WHC-SD-NR-ER-105 Rev. 0

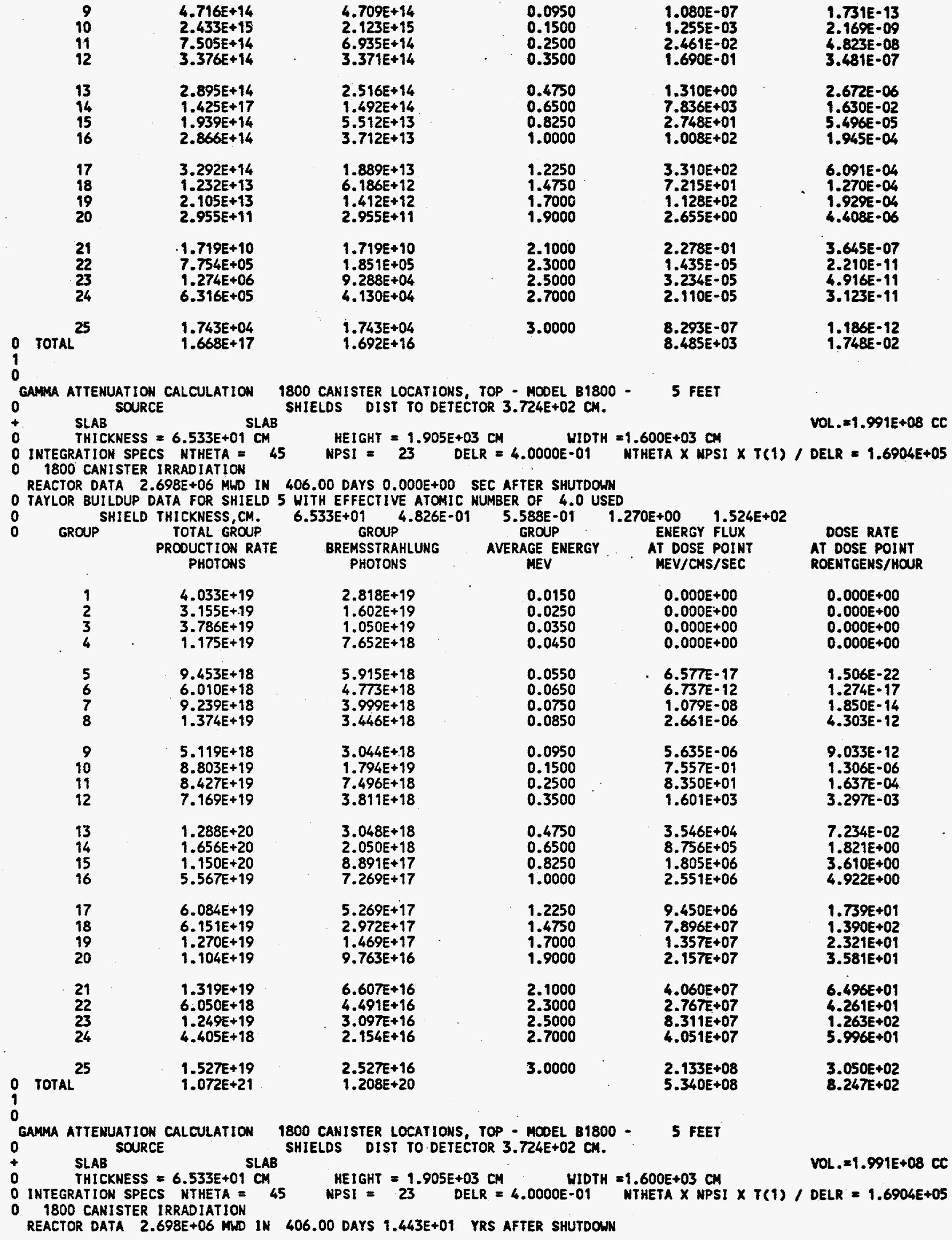


WHC-SD-NR-ER-105 Rev. 0

- TAYLOR BUILDUP DATA FOR SHIELD 5 UITH EFFECTIVE ATOMIC MLABER OF 4.0 USED

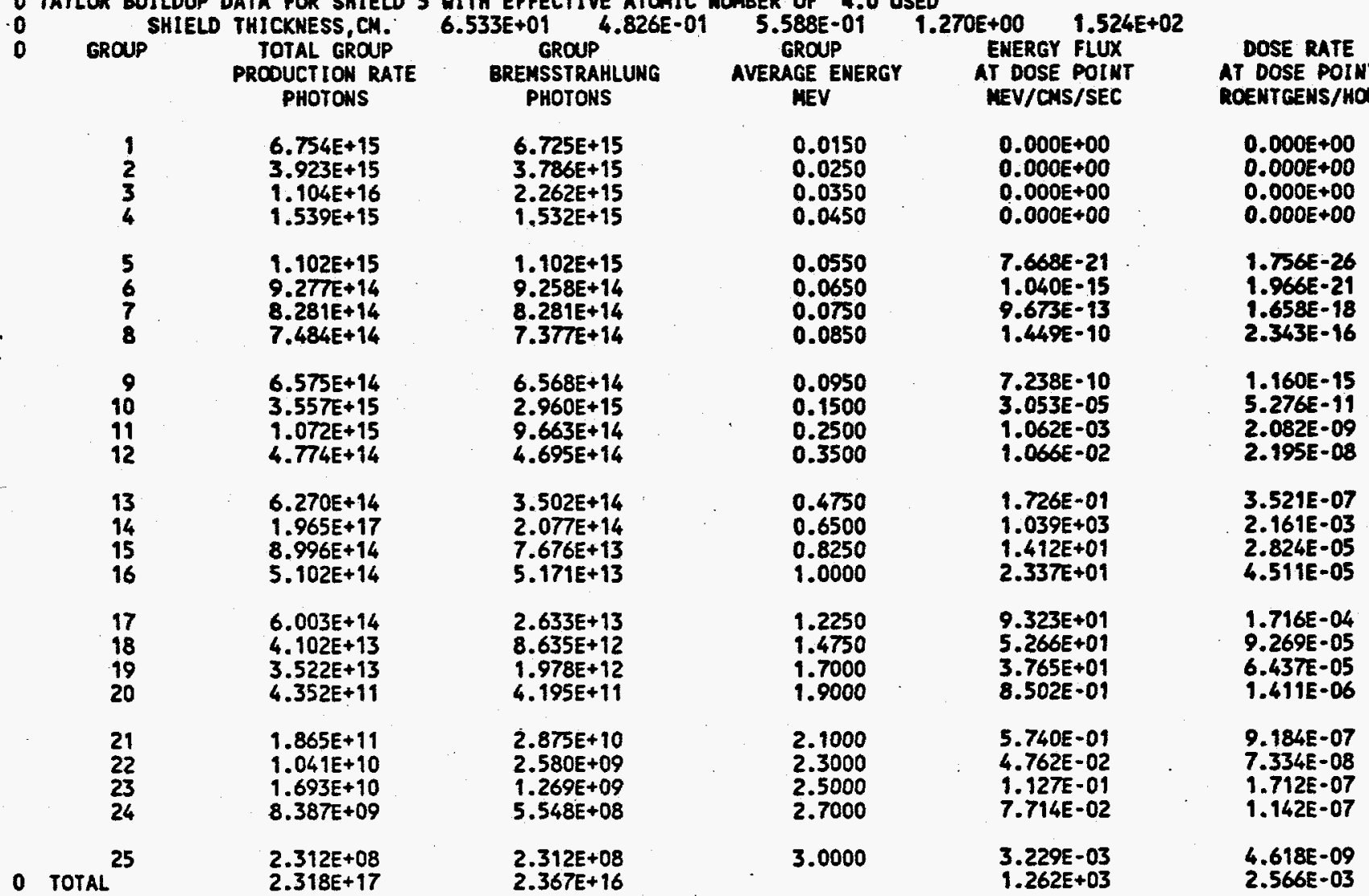
GAMMA ATTENUATION CALCULATION 1800 CANISTER LOCATIONS, TOP - MOOEL B $1800-\quad 5$ FEET
SOUIELOS DIST TO DETECTOR $3.724 E+02 \mathrm{CM}$.

+
0 THICKNESS $=6.533 E+01 \mathrm{CM} \quad$ HEIGHT $=1.905 E+03 \mathrm{CM} \quad{ }_{4}^{\text {WIDTH }=1.600 E+03 \mathrm{CM}}$

VOL. $=1.991 E+08 \mathrm{CC}$

0 INTEGRATION SPECS NTHETA $=45$ NPSI $=23$ DELR $=4.0000 E-01$ NTHETA $\times$ NPSI $\times$ T(1) $/$ DELR $=1.6904 E+05$ 1800 CANISTER IRRAD IATION

REACTOR DATA 2.698E+06 MWD IN 406.00 DAYS 1.715E+01 YRS AFTER SHUTDOWN

0 TAYLOR BUILDUP DATA FOR SHIELO 5 WITH EFFECTIVE ATOMIC MUNBER OF 4.0 USED

$\begin{array}{lllllll}0 & \text { SHIELD THICKNESS, CM. } & 6.533 E+01 & 4.826 E-01 & 5.588 E-01 & 1.270 E+00 & 1.524 E+02\end{array}$

$\begin{array}{cc}\text { GROUP } & \begin{array}{r}\text { THCTAL GROUP } \\ \text { PROOUCTION RAT } \\ \text { PHOTONS } \\ \end{array} \\ 1 & 6.301 E+15 \\ 2 & 3.630 E+15 \\ 3 & 1.035 E+16 \\ 4 & 1.433 E+15 \\ 5 & 1.030 E+15 \\ 6 & 8.668 E+14 \\ 7 & 7.742 E+14 \\ 8 & 6.935 E+14 \\ 9 & \\ 9 & 6.150 E+14 \\ 10 & 3.282 E+15 \\ 11 & 9.968 E+14 \\ 12 & 4.433 E+14 \\ 13 & 4.870 E+14 \\ 13 & 1.840 E+17 \\ 15 & 5.219 E+14 \\ 16 & 4.522 E+114 \\ 17 & 5.285 E+14 \\ 18 & 2.637 E+13 \\ 19 & 3.174 E+13 \\ 20 & 3.884 E+11\end{array}$

BREMSSTRAHLUNG AVERAGE ENERGY PHOTONS

$\begin{array}{ll}6.274 E+15 & 0.0150 \\ 3.535 E+15 & 0.0250 \\ 2.111 E+15 & 0.0350 \\ 1.431 E+15 & 0.0450 \\ 1.030 E+15 & 0.0550 \\ 8.652 E+14 & 0.0650 \\ 7.742 E+14 & 0.0750 \\ 6.898 E+14 & 0.0850 \\ 6.143 E+14 & 0.0950 \\ 2.769 E+15 & 0.1500 \\ 9.039 E+14 & 0.2500 \\ 4.392 E+14 & 0.3500 \\ 3.277 E+14 & 0.4750 \\ 1.943 E+14 & 0.6500 \\ 7.180 E+13 & 0.8250 \\ 4.835 E+13 & 1.0000 \\ 2.460 E+13 & 1.2250 \\ 8.060 E+12 & 1.4750 \\ 1.841 E+12 & 1.7000 \\ 3.861 E+11 & 1.9000\end{array}$

ENERGY FLUX
AT DOSE POINT
MEV/CHS/SEC

$0.000 E+00$

$0.000 E+00$

$0.000 E+00$

$0.000 E+00$

7.163E-21

$9.716 \mathrm{E}-16$

$9.044 E-13$

$1.343 E-10$

6.770E-10

2.818E-05

$9.876 \mathrm{E}-04$

9.897E-03

1.340E-01

$9.730 E+02$

8. $192 E+00$

2.072E+01

$8.209 E+01$

$3.385 \mathrm{E}+01$

$3.392 E+01$

7.589E-01
DOSE RATE AT DOSE POINT ROENTGENS/HOUR

$0.000 E+00$

$0.000 E+00$

$0.000 E+00$

$0.000 E+00$

$1.640 \mathrm{E}-26$

$1.837 \mathrm{E}-21$

$1.550 \mathrm{E}-18$

2.171E-16

$1.085 E-15$

$4.869 E-11$

$1.936 E-09$

$2.039 E-08$

2.734E-07

2.024E-03

$1.638 E-05$

3.998E-05

1.510E-OS

$5.957 \mathrm{E}-05$

5.800E-05

1.260E-06 
WHC-SD-NR-ER-105 Rev. 0

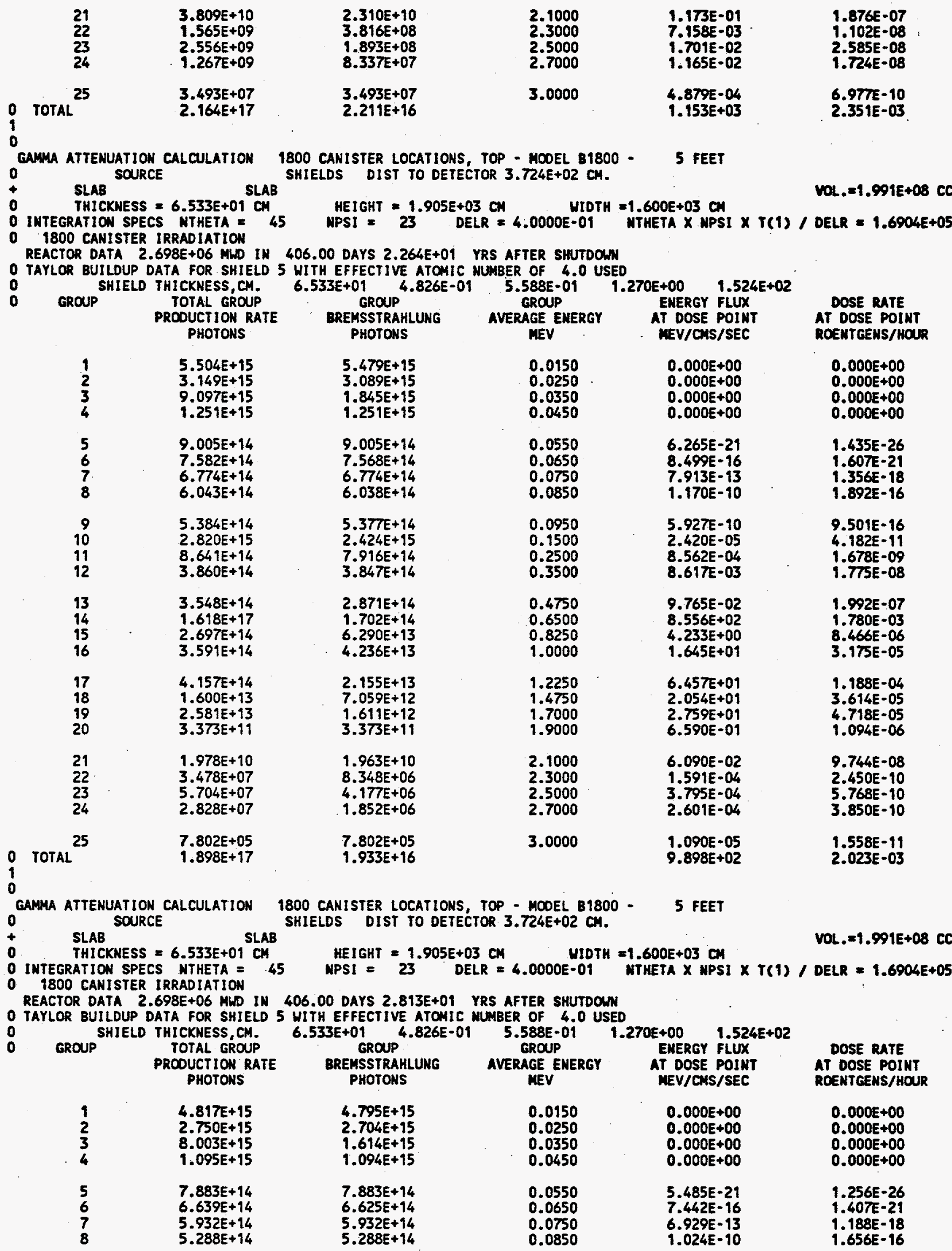


WHC-SD-NR-ER-105 Rev. 0

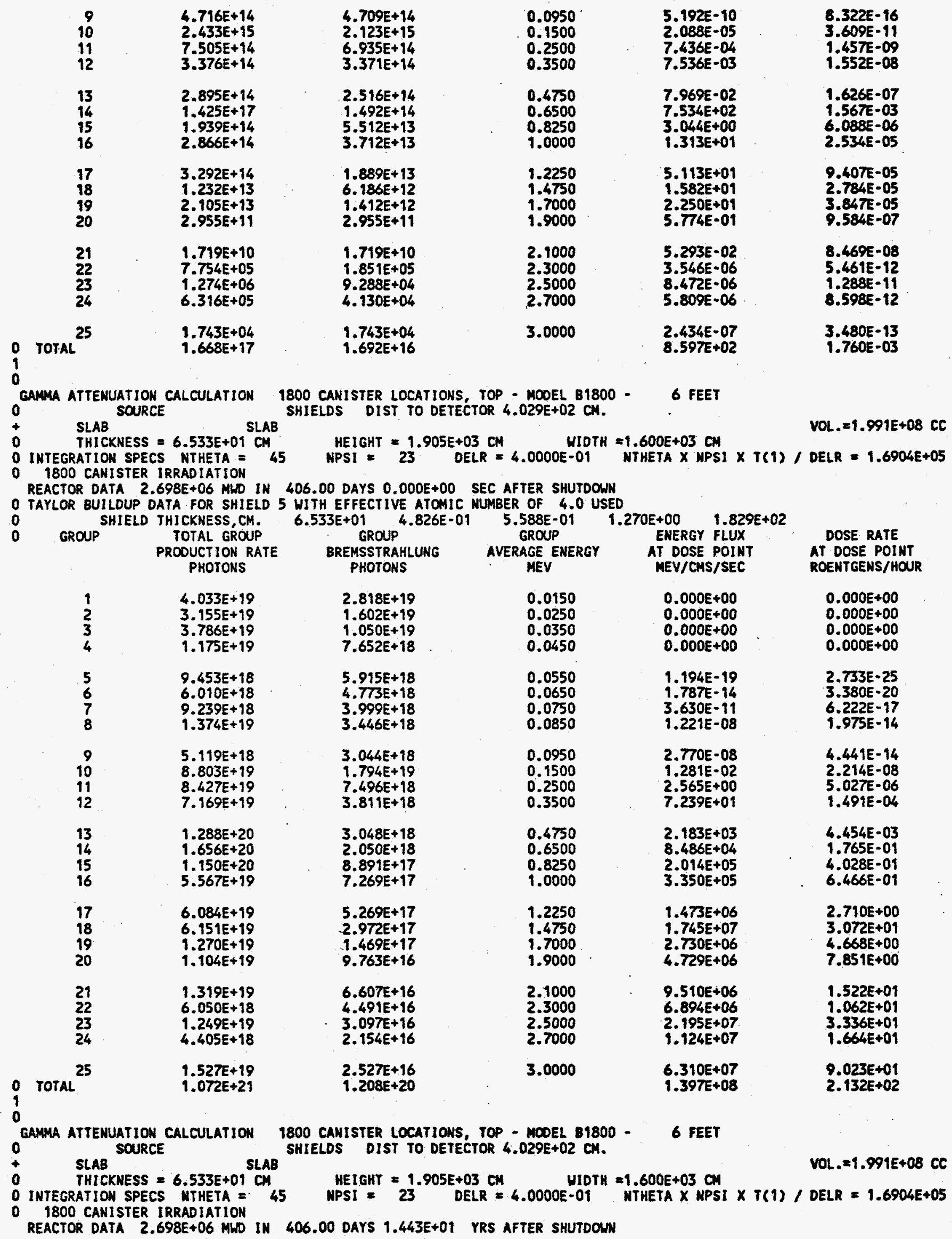


WHC-SD-NR-ER-105 ReV. 0

O TAYLOR BUILDUP DATA FOR SHIELD 5 WITH EFFECTIVE ATOMIC MUNBER OF 4.0 USED

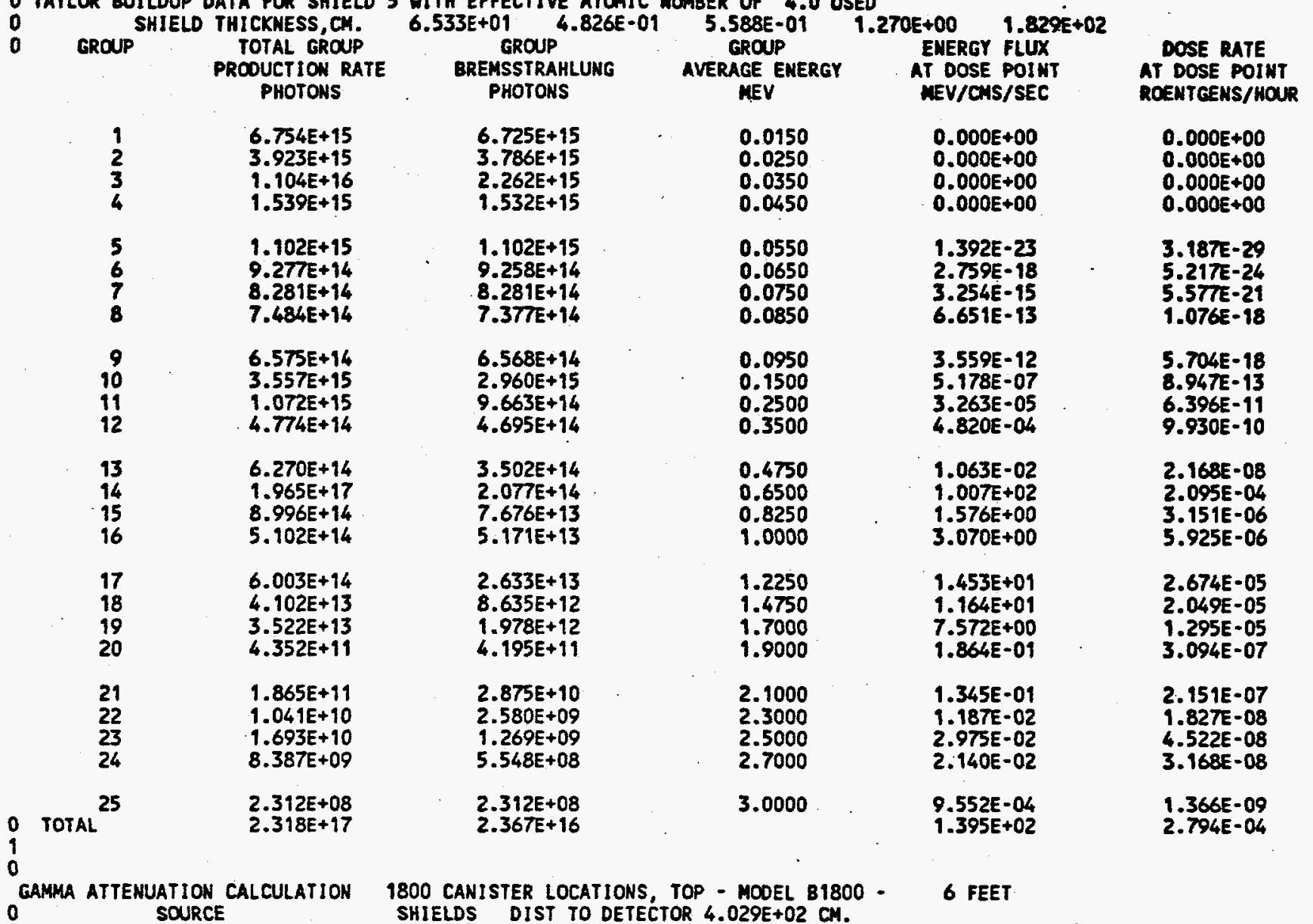
SHIELDS DIST TO DETECTOR 4.029E+02 CM.

THHICKHESS $=6.533 E+01 \mathrm{CM} \quad$ HEIGHT $=1.905 E+03 \mathrm{CM} \quad$ HIDTH $=1.600 \mathrm{CM}+03 \mathrm{CM}$

0 INTEGRATION SPECS NTHETA $=45$ NPSI $=23 \quad$ DELR $=4.0000 E-01$ NTHETA $\times$ NPSI $\times$ T(1) $/$ DELR $=1.6904 E+05$ 1800 CANISTER IRRADIATION

REACTOR DATA 2.698E+06 MWD IN 406.00 DAYS 1.715E+01 YRS AFTER SHUTDOWN

0 TAYLOR BUILDUP DATA FOR SHIELD 5 WITH EFFECTIVE ATOMIC NUMBER OF 4.0 USED

\begin{tabular}{|c|c|c|c|c|c|}
\hline GROUP & $\begin{array}{l}\text { TOTAL GROUP } \\
\text { PROOUCTION RATE } \\
\text { PHOTONS }\end{array}$ & $\begin{array}{l}\text { GROUP } \\
\text { BREMSSTRAHLUNG } \\
\text { PHOTONS }\end{array}$ & $\begin{array}{l}\text { GROUP } \\
\text { AVERAGE ENERGY } \\
\text { MEV }\end{array}$ & $\begin{array}{l}\text { ENERGY FLUX } \\
\text { AT DOSE POINT } \\
\text { MEV/CNS/SEC }\end{array}$ & $\begin{array}{l}\text { DOSE RATE } \\
\text { AT DOSE POINT } \\
\text { ROENTGENS/HO }\end{array}$ \\
\hline $\begin{array}{l}1 \\
2 \\
3 \\
4\end{array}$ & $\begin{array}{l}6.301 E+15 \\
3.630 E+15 \\
1.035 E+16 \\
1.433 E+15\end{array}$ & $\begin{array}{l}6.274 E+15 \\
3.535 E+15 \\
2.111 E+15 \\
1.431 E+15\end{array}$ & $\begin{array}{l}0.0150 \\
0.0250 \\
0.0350 \\
0.0450\end{array}$ & $\begin{array}{l}0.000 E+00 \\
0.000 E+00 \\
0.000 E+00 \\
0.000 E+00\end{array}$ & $\begin{array}{l}0.000 E+00 \\
0.000 E+00 \\
0.000 E+00 \\
0.000 E+00\end{array}$ \\
\hline $\begin{array}{l}5 \\
6 \\
7 \\
8\end{array}$ & $\begin{array}{l}1.030 E+15 \\
8.668 E+14 \\
7.742 E+14 \\
6.935 E+14\end{array}$ & $\begin{array}{l}1.030 E+15 \\
8.652 E+14 \\
7.742 E+14 \\
6.898 E+14\end{array}$ & $\begin{array}{l}0.0550 \\
0.0650 \\
0.0750 \\
0.0850\end{array}$ & $\begin{array}{l}1.300 E-23 \\
2.578 E-18 \\
3.042 E-15 \\
6.164 E-13\end{array}$ & $\begin{array}{l}2.977 E-29 \\
4.874 E-24 \\
5.214 E-21 \\
9.967 E-99\end{array}$ \\
\hline $\begin{array}{r}9 \\
10 \\
11 \\
12\end{array}$ & $\begin{array}{l}6.150 E+14 \\
3.282 E+15 \\
9.968 E+14 \\
4.433 E+14\end{array}$ & $\begin{array}{l}6.143 E+14 \\
2.769 E+15 \\
9.039 E+14 \\
4.392 E+14\end{array}$ & $\begin{array}{l}0.0950 \\
0.1500 \\
0.2500 \\
0.3500\end{array}$ & $\begin{array}{l}3.328 E-12 \\
4.778 E-07 \\
3.034 E-05 \\
4.476 E-04\end{array}$ & $\begin{array}{l}5.335 E-18 \\
8.256 E-13 \\
5.947 E-11 \\
9.222 E-10\end{array}$ \\
\hline $\begin{array}{l}13 \\
14 \\
15 \\
16\end{array}$ & $\begin{array}{l}4.870 E+14 \\
1.840 E+17 \\
5.219 E+14 \\
4.522 E+14\end{array}$ & $\begin{array}{l}3.277 E+14 \\
1.943 E+14 \\
7.180 E+13 \\
4.835 E+13\end{array}$ & $\begin{array}{l}0.4750 \\
0.6500 \\
0.8250 \\
1.0000\end{array}$ & $\begin{array}{l}8.254 E-03 \\
9.431 E+01 \\
9.141 E-01 \\
2.721 E+00\end{array}$ & $\begin{array}{l}1.684 E-08 \\
1.962 E-04 \\
1.828 E-06 \\
5.252 E-06\end{array}$ \\
\hline $\begin{array}{l}17 \\
18 \\
19 \\
20\end{array}$ & $\begin{array}{l}5.285 E+14 \\
2.637 E+13 \\
3.174 E+13 \\
3.884 E+11\end{array}$ & $\begin{array}{l}2.460 E+13 \\
8.060 E+12 \\
1.841 E+12 \\
3.861 E+11\end{array}$ & $\begin{array}{l}1.2250 \\
1.4750 \\
1.7000 \\
1.9000\end{array}$ & $\begin{array}{l}1.279 E+01 \\
7.482 E+00 \\
6.823 E+00 \\
1.664 E-01\end{array}$ & $\begin{array}{l}2.354 E-05 \\
1.317 E-05 \\
1.167 E-05 \\
2.762 E-07\end{array}$ \\
\hline
\end{tabular}


WHC-SD-NR-ER-105 Rev. 0

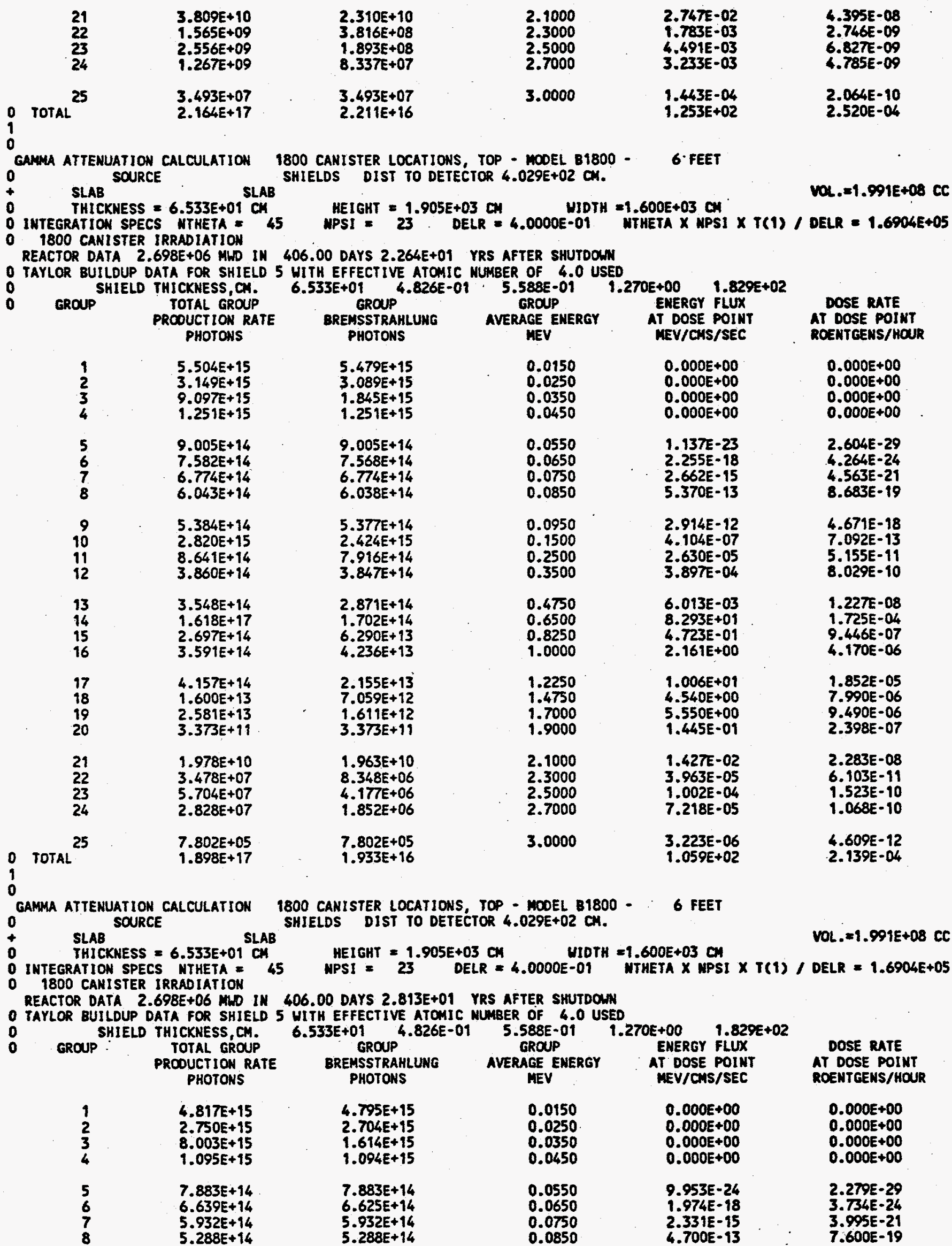


WHC-SD-NR-ER-105 ReV. 0

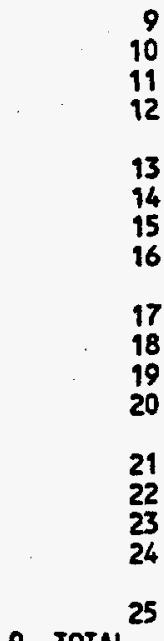

o. TOTAL
4.716E+14

2. $433 E+15$

7.505E+16

$3.376 E+14$

$2.895 E+14$

$1.425 E+17$

$1.939 E+14$

$2.866 E+14$

3. $292 E+14$

1. $232 E+13$

2. $105 E+13$

$2.955 E+11$

$1.719 E+10$

$7.754 E+05$

$1.274 E+06$

$6.316 E+05$

$1.743 E+04$

$1.668 \mathrm{E}+17$
4.709E+14

2. $123 E+15$

$6.935 E+14$

$3.371 E+14$

$2.516 E+14$

$1.492 E+14$

$5.512 E+13$

$3.712 E+13$

$1.889 E+13$

$6.186 E+12$

$1.412 E+12$

$2.955 E+11$

$1.719 E+10$

$1.851 E+05$

$9.288 E+04$

$4.130 E+04$

$1.743 E+04$ $1.692 E+16$
0.0950

0.1500

0.2500

0.3500

0.4750

0.6500

0.8250

1.0000

1.2250

1.4750

1.7000

1.9000

2.1000

2.3000

2.5000

2.7000

3.0000
2.552E- 12

3.542E-07

2.284E-05

3.409E-04

4.907E-03

$7.302 E+01$

3.396E-01

$1.724 E+00$

$7.969 E+00$

$3.497 E+00$

$4.525 E+00$

$1.266 E=01$

1.240E-02

8.836E-07

2.237E-06

1.612E-06

$7.199 \mathrm{E}-08$

$9.122 \mathrm{E}+01$
$4.091 E-18$

$6.120 \mathrm{E}-13$

4.47TE-11

7.022E-10

1.001E-08

$1.519 E-04$

6.793E-07

3.328E-06

$1.466 E-05$

6.155E-06

7.73BE-06

2.101E-07

1.984E-08

$1.361 E-12$

3.401E-12

2.386E- 12

$1.029 E-13$

$1.847 \mathrm{E}-04$ 
WHC-SD-NR-ER-105 ReV. 0

\section{APPENDIX E}

INDEPENDENT REVIEWER'S COMMENT

$E-1$ 
WHC-SD-NR-ER-105 Rev. 0

This page intentionally left blank. 


\section{CHECKLIST FOR INDEPENDENT TECHNICAL REVIEW}

\section{DOCUMENT REVIEWED}

NUMBER: $\quad$ WHC-SD-NR-ER-105 ReV. 0

TITLE: CONSOLIDATED FUEL SHIELDING CALCULATION

AUTHOR(s): H.D. WITTEKIND

I. Method(s) of Review

(X) Input data checked for accuracy

( ) Independent calculation performed

( ) Hand calculation

( ) Alternate computer code:

() Comparison to experiment or previous results

() Alternate method (define)

II. Checklist (either check or enter NA if not applied)

(X) Task completely defined

(X) Activity consistent with task specification

(X) Necessary assumptions explicitly stated and supported

$(X)$ Resources properly identified and referenced

$(X)$ Resource documentation appropriate for this application

(X) Input data explicitly stated

$(X)$ Input data verified to be consistent with original source

$(x)$ Geometric model adequate representation of actual geometry

(X) Material properties appropriate and reasonable

(X) Mathematical derivations checked including dimensional consistency

(X) Hand calculations checked for errors

(X) Assumptions explicitly stated and justified

(X) Computer software appropriate for task and used within range of validity

(NA) Use of resource outside range of established validity is justified

(X) Software runstreams correct and consistent with results

$(X)$ Software output consistent with input

(X) Results consistent with applicable previous experimental or analytical findings

(X) Results and conclusions address all points and are consistent with task requirements and/or established limits or criteria

(X) Conclusions consistent with analytical results and established Timits

(NA) Uncertainty assesment appropriate and reasonable

(X) Other (define) Uncertainties, al though not specificially

addressed, are covered by using upper bounds.

III. Comments: The results of this study adequately address the water

shielding requirements for consolidated storage of fuel

IV. REVIEWER:Robertet sinoms cancers DATE: July 26, 1994 
WHC-SD-NR-ER-105 Rev. 0

This page intentionally left blank. 